\title{
Hazardous waste classification
}

Amendments to the European Waste Classification regulation

- what do they mean and what are the consequences?

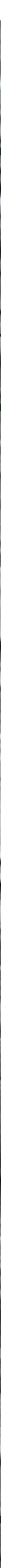



(III) norden 



\section{Hazardous waste classification}

Amendments to the European Waste Classification regulation - what do they mean and what are the consequences?

Margareta Wahlström, Jutta Laine-Ylijoki, Ola Wik, Anke Oberender and Ole Hjelmar 


\section{Hazardous waste classification}

Amendments to the European Waste Classification regulation - what do they mean and what are the consequences?

Margareta Wahlström, Jutta Laine-Ylijoki, Ola Wik, Anke Oberender and Ole Hjelmar

ISBN 978-92-893-4532-3 (PRINT)

ISBN 978-92-893-4533-0 (PDF)

ISBN 978-92-893-4534-7 (EPUB)

http://dx.doi.org/10.6027/TN2016-519

TemaNord 2016:519

ISSN 0908-6692

(C) Nordic Council of Ministers 2015

Layout: Hanne Lebech

Cover photo: VTT Technical Research Centre of Finland Ltd.

Print: Rosendahls-SchultzGrafisk

Printed in Denmark

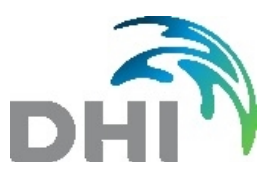

SGI Swedish Geotechnical Institute

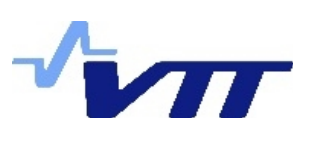

This publication has been published with financial support by the Nordic Councilof Ministers. However, the contents of this publication do not necessarily reflect the views, policies or recommendations of the Nordic Council of Ministers.

www.norden.org/nordpub

\section{Nordic co-operation}

Nordic co-operation is one of the world's most extensive forms of regional collaboration, involving Denmark, Finland, Iceland, Norway, Sweden, and the Faroe Islands, Greenland, and Åland.

Nordic co-operation has firm traditions in politics, the economy, and culture. It plays an important role in European and international collaboration, and aims at creating a strong Nordic community in a strong Europe.

Nordic co-operation seeks to safeguard Nordic and regional interests and principles in the global community. Common Nordic values help the region solidify its position as one of the world's most innovative and competitive.

\section{Nordic Council of Ministers}

Ved Stranden 18

DK-1061 Copenhagen K

Phone (+45) 33960200

www.norden.org 


\section{Contents}

Preface 7

Acknowledgements

Summary Amendments to the European Waste Classification regulation - what do they mean and what are the consequences?

Terms and abbreviations.....................................................................................................13

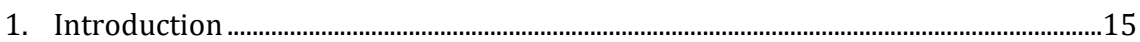

1.1 Objective of the study....................................................................................15

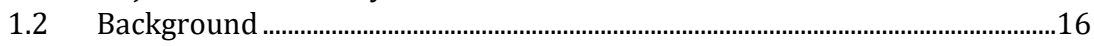

1.3 Legal and practical implications of waste classifications .................................26

1.4 Hazardous waste amounts generated in Nordic countries..............................27

2. Tiered procedure for hazard property assessment.......................................................31

2.1 Overview of general methodology …………......................................................

2.2 Step 1: Classification based on the European List of Waste ............................32

2.3 Step 2: Screening at a high level for non-applicable hazardous properties.................................................................................................................33

2.4 Step 3a: Assessment of hazardous properties based on total content of substance and a worst case scenario......................................................................33

2.5 Step 3b: Assessment of hazardous properties based on performance of tests..........................................................................................................................3

2.6 Step 3c: Assessment of hazardous properties based on the principle of bridging........................................................................................................................ 34

2.7 Step 4: Assessment of hazardous properties based on substance content, leaching data and chemical speciation...................................................................35

3. Tools and methods for data procurement...................................................................

3.1 Requirements set in the CLP regulation $(1272 / 2008)$......................................37

3.2 Determination of substances in waste................................................................39

3.3 Speciation of substances by geochemical modelling .........................................4

4. The use of alkali reserve-method for determination of Hazard properties "irritant" (HP4) and "corrosive" (HP8)...

4.1 Approach for determination of HP4/HP8 properties..........................................49

4.2 Use of $\mathrm{pH}$ as an HP4/HP8 indicator..................................................................51

4.3 Experience and applicability of the alkali reserve method..............................54

4.4 Use of in vitro test methods .................................................................................56

4.5 Recommendations for testing of $\mathrm{CaO}$ and/or $\mathrm{Ca}(\mathrm{OH})_{2}$ wastes .......................57

5. Use of calculation methods and test methods for determination of hazardous property "ecotoxicity" (HP 14) ....................................................................................59

5.1 Assessment of ozone depleting properties according to the CLP ..................60

5.2 Hazard classification of ecotoxic properties according to the CLP ................60

5.3 Use of calculation methods in the assessment of HP 14..................................64

$5.4 \quad$ Use of biotest in assessment of HP 14...............................................................76 
6. Implications of the revised waste classification legislation on the management of selected waste streams...................................................................................................... 81

6.1 Construction \& demolition waste: concrete waste ............................................ 82

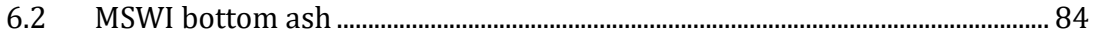

6.3 Ashes from renewable energy sources............................................................... 85

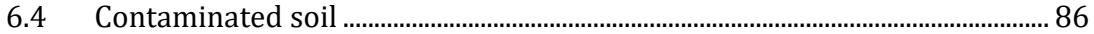

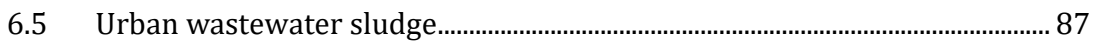

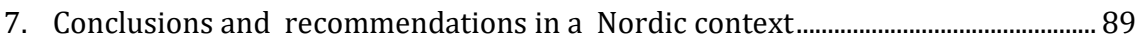

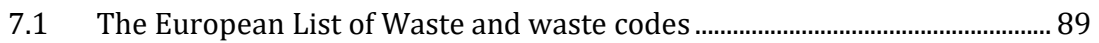

7.2 Methods and tools for hazard assessment ......................................................... 90

7.3 Specific HP4/HP8 issues ............................................................................................. 93

7.4 Specific HP 14 issues............................................................................................. 94

Sammanfattning ......................................................................................................................... 95

Appendix 1: Testing of alkali reserve method and ecotoxicity methods on selected mineral wastes ................................................................................................................... 97

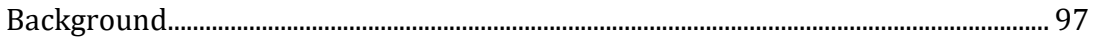

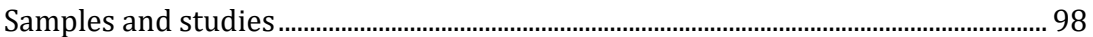

References..............................................................................................................................106

Appendix 2: Ecotoxicity testing of 6 wastewater sludges.................................................107

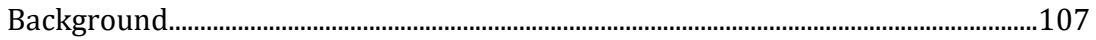

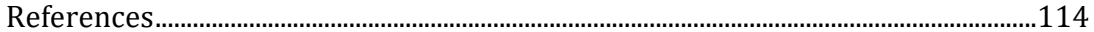

Appendix 3: Composition data on bottom ash ..............................................................115

Appendix 4: Geochemical modelling of Zn-species in incineration bottom ash .........117 


\section{Preface}

The Nordic countries have long traditions in promoting sustainable production and consumption, environmentally friendly technology and green economic growth. As part of the Nordic Environmental Action Programme for 2013-18, the Nordic Waste Group under the Nordic Council of the Ministers has initiated and supported several activities and projects on sustainable and efficient waste processing in the Nordic Region. In the recent years the Nordic Waste Group has increasingly focused on waste prevention and promotion of the circular economy.

In addition to closing the material loops, it is also important to have adequate information of risks related to hazardous properties of wastes and legal restrictions in waste recycling. Explicit rules for the hazardous waste classification and consistency in assessment procedures steer technology development of detoxification and advanced separation of hazardous waste streams for producing resources for the future.

This report presents challenges in the hazardous waste classification. The authors express their views on the interpretation of the waste status, specifically focusing on potentially recyclable high volume waste streams. Hopefully the results of this work can be utilized as background information in coming decisions on open criteria and in future guidance documents on the interpretation of waste status. The report also gives a base for the development of waste or sector specific guidance.

\section{Marianne Bigum}

Chairman of the Nordic Waste Group 


\section{Acknowledgements}

This document is the final report on the project entitled: "Amendments to the European Waste Catalogue - classification of waste as hazardous consequences for landfilling and recycling" financed by Nordic Council of Ministers, the Nordic Waste Group (NAG Group). The project was initiated in December 2013 and was finished in March 2016. Parts of the project results were also presented at an international workshop held on 12 May 2015 at VTT, Finland with several invited key lecturers from EC consultants (France, Germany) and Austria. The workshop was well attended with 40 key stakeholders from Denmark, Finland and Sweden.

The main objective of the project has been to reach an understanding of the potential consequences of the changed waste classification rules on a few large streams of non-hazardous waste (if classified as hazardous) and also to influence and clarify the interpretation of unclear properties (especially concerning tools for assessment of hazardous properties). The project has particularly focused on a few hazardous properties, namely HP 4 irritant, HP 8 corrosive, and HP 14 ecotoxicity.

The project work has been followed by a Nordic Steering Group consisting of following members:

- Eevaleena Häkkinen, Finnish Environment Institute, Finland (Chairman).

- Thilde Fruergaard Astrup, Danish EPA, Denmark.

- Axel Hullberg, Swedish EPA, Sweden.

The project has been coordinated by VTT from Finland. The project group consisted of the following persons:

- Margareta Wahlström, VTT, Finland (project manager).

- Jutta Laine-Ylijoki, VTT, Finland.

- Ola Wik, SGI, Sweden.

- Anke Oberender, DHI, Denmark (participation in 2013/beginning of 2014).

- Ole Hjelmar, Danish Waste Solutions ApS, Denmark.

March 2016 


\section{Summary}

\section{Amendments to the European Waste Classification regulation - what do they mean and what are the consequences?}

In European legislation, waste is classified either as hazardous or nonhazardous. Hazardous waste is a waste that due to its (intrinsic) chemical or other properties poses a risk to the environment and/or human health. The legislation was revised in 2014 in order to align it with the chemicals regulation, the CLP Regulation. The classification is primarily based on the European List of Waste (2014/955/EU). In some cases a particular type of waste on the list can be either hazardous or non-hazardous depending on the specific properties of the waste and in these cases the waste status has to be assessed based on its hazardous properties. The Commission Regulation No 1357/2014 defines the hazardous properties for hazardous waste classification as well as substance-specific limit values. It also refers to other properties that may render a waste material hazardous but it does not always prescribe the test methods to be used to assess these properties.

This study discusses the amendments of the regulation, the potential consequences and some of the practical challenges associated with the changes. A tiered assessment procedure for hazard property assessment is proposed, and an overview is provided of the tools and methods available for data procurement when the assessment needs to be done based on the hazardous properties. Special focus is placed on tools for evaluation of the hazardous properties "irritant (HP4)", "corrosive (HP8)" and "ecotoxicity (HP14)". The last property was temporarily left open in the revised legislation for assessment of hazardous properties with a reference to the previously existing rules. The four calculation methods proposed by the Commission for the assessment of the HP14 are compared and evaluated with respect to their applicability. This report also brings up the implications of the waste status on the management of selected waste streams generated in large amounts in Europe. 
Among the ambiguities and needs for further clarification and guidance in waste classification (information gaps) identified are the following:

- There is a lack of information on why certain waste are classified as hazardous or non-hazardous in the European list of waste.

- Further specifications are needed on chemical analytical methods to be used to determine the content of substances in waste materials as part of the classification.

- Common protocols are needed for selection of substances of concern in specific waste streams and guidance is needed on choice of hazard statements in case of no harmonised classification (including $M$ factors if required in assessment).

The study has further led to a number of conclusions and recommendations, including the following:

- Further development and use of European testing standards for wastes are needed.

- It could be reasonable to exempt elevated $\mathrm{pH}(>11.5)$ and alkalinity as a trigger for HP4/HP8 hazard classification for ashes, slags, concrete waste and lime stabilised wastewater sludges. If such exemptions are not possible, the use of the CEN methods (especially $\mathrm{pH}$ dependence test with continuous $\mathrm{pH}$ control) is recommended for the determination of the alkali reserve in waste. The currently proposed biotest methods for HP14 assessment often under- or overestimate the risks related to leached substances and there is insufficient correlation between the results of the biotests and the results of the calculation methods.

- Two of four proposed calculation methods for the ecotoxicity assessment are regarded as potential. Both methods (named method 1 and 2) take into consideration both aquatic acute and aquatic chronic properties. The method 2 includes $M$ factors used in CLP to increase weight to environmentally very toxic substances and is fully in alignment with the CLP. The method 1 (lacking M factors) is in line with the practices performed in several member states and is to some degree in alignment with CLP. However, harmonized M factors have currently been defined only for a very limited number of substances. Therefore the method 1 leads to less uncertainty and less change in current situation. 


\section{Terms and abbreviations}

- $A D R$

European agreement concerning the international carriage of dangerous goods by road (latest updated in 2015).

- Annex III

Commission Regulation (EU) No 1357/2014 of 18 December 2014 replacing Annex III to Directive 2008/98/EC of the European Parliament and of the Council on waste and repealing certain Directives (revised Annex III).

- C\&L inventory

ECHA database containing classification and labelling information on notified and registered substances received from manufacturers and importers.

- $C E N$

European Committee for Standardization.

- $\quad C L P$

Regulation (EC) No 1272/2008 of the European Parliament and of the council of 16 December 2008 on classification, labelling and packaging of substances and mixtures, amending and repealing Directives 67/548/EEC and 1999/45/EC, and amending Regulation (EC) No 1907/2006 (Classification, Labelling and Packaging regulation).

- Cut-off value Lowest concentration to be considered in the assessment.

- $D S D$

Dangerous Substances Directive (67/548/EEC).

- $E R V$

Ecotoxicological reference values e.g. EC50 or NOEC for the free and dissolved metal ion.

- $E W C$

6 digit codes in LoW related to the waste source and waste type (European Waste Code). 
- Hazard statements

Set of standardized phrases about the physical, health and environmental hazards of chemical substances and mixtures that are part CLP and of the Globally Harmonized System of Classification and Labelling of Chemicals (GHS).

- Hazard properties Set of physical, health and environmental properties that render waste hazardous (HP).

- $J R C$

Joint Research Centre.

- $L o W$

2014/955/EU: Commission Decision of 18 December 2014 amending Decision 2000/532/EC on the list of waste pursuant to Directive 2008/98/EC of the European Parliament and of the Council (European List of Waste).

- $M S W I$

Municipal Solid Waste Incinerator.

- $\quad$ NACE

Nomenclature of Economic Activities (the European statistical classification of economic activities used by Eurostat).

- $\quad P C B$

Polychlorinated biphenyls.

- $P O P$

Persistent organic pollutant.

- UVCB substances

Substances of Unknown or Variable Composition, Complex reaction Products or Biological Materials.

- $\quad W F D$

Directive 2008/98/EC of the European parliament and of the council of 19 November 2008 on waste and repealing certain Directives (Waste Framework Directive). 


\section{Introduction}

\subsection{Objective of the study}

The objective of this study has been to provide guidance on the classification of specific waste streams and to evaluate methods or tools for the assessment of hazardous properties relevant for selected waste streams. The project also aims to evaluate the potential impacts on the whole waste handling chain that may be caused by the revision of the European rules of classification of waste as hazardous or non-hazardous which has actually been implemented during the period when this study was carried out.

The project has included consideration of the following aspects:

- Identification of a few key waste streams generated in large amounts for which the waste classification might influence the conditions of utilisation or disposal.

- Guidance on the interpretation of specific hazardous waste properties relevant for the selected waste streams and recommendation of tools for evaluation of the properties based on waste characteristics (e.g. composition, use of modelling tools or based on results from testing).

- Review of tests on Nordic waste materials, the applicability of standardised CEN test methods and test methods applied for hazard classification of chemicals in this context.

- Recommendations of modified or simplified test procedures in some cases.

This study has mainly focused on the following hazardous properties (HPs):

- HP4 "Irritant" / HP8 "Corrosive".

- HP14 "Ecotoxicity". 
However, a general overall methodology for classification of waste which applies to all HPs is also outlined.

The target group for this report includes all the stakeholders involved such as the authorities, regulators, waste producers, consultants, and testing laboratories.

\subsection{Background}

\subsubsection{Legislation for classification of waste}

The classification of waste as non-hazardous or hazardous is regulated by the Waste framework directive (WFD). ${ }^{1}$ Classification criteria related to the properties that may render waste hazardous are regulated in the revised Annex III to the WFD (Annex III), ${ }^{2}$ while classification criteria related to the waste source and waste type is regulated in the European List of Waste (LoW). ${ }^{3}$

The LoW is a key document that establishes a harmonised classification system for wastes, including a listing of hazardous and non-hazardous wastes. The waste entries in the LoW are legally binding but Member States may in certain cases deviate from LoW classification depending on if the waste exhibits any hazardous characteristics. ${ }^{4}$ Classification of waste in individual Member States that deviates from the absolute hazardous and non-hazardous entries in the LoW shall be notified to the EU Commission without delay. ${ }^{5}$ A periodical review of the LoW is foreseen when more scientific information is available and in the light of notifications received. However, the list includes so-called "mirror entries" i.e. waste materials which should be classified as either non-hazardous or

\footnotetext{
${ }^{1}$ Directive 2008/98/EC of the European parliament and of the council of 19 November 2008 on waste and repealing certain Directives http://eur-lex.europa.eu/legal-content/EN/TXT/?uri=CELEX:32008L0098 ${ }^{2}$ Commission Regulation (EU) No 1357/2014 of 18 December 2014 replacing Annex III to Directive 2008/98/EC of the European Parliament and of the Council on waste and repealing certain Directives Text with EEA relevance http://eur-lex.europa.eu/legal-content/EN/TXT/?uri=CELEX:32014R1357 3 2014/955/EU: Commission Decision of 18 December 2014 amending Decision 2000/532/EC on the list of waste pursuant to Directive 2008/98/EC of the European Parliament and of the Council Text with EEA relevance http://eur-lex.europa.eu/legal-content/EN/TXT/?uri=celex:32014D0955.

${ }^{4}$ WFD article 7. 1 and article 7.6. There are a number of absolute non-hazardous entries in LoW that might display hazardous properties and vice versa. In those cases LoW overrides the property related definition of hazardous waste in Annex III and no assessment of the hazardous properties is required.

5 WFD article 7. 2 and article 7.3 regulates the re-classification of hazardous waste or non-hazardous waste that does or does not display one or more of the properties listed in Annex III. There is no background documentation that provides information on the specific hazard properties that triggers classification of hazardous entries in LOW when the Commission and the member states discussed the LoW entries.
} 
hazardous, depending on its hazardous properties and/or content of hazardous substances. ${ }^{6}$ The assessment of hazardous properties is based on concentration limits in Annex III to Commission Regulation (EU) No $1357 / 2014$ or on the results of tests. The LoW also provides further provisions for the assessment of hazardous properties and the classification of waste:

- Definitions of some key terms such as "Hazardous substance"; "PCBs" (although insufficient); "Stabilisation", "Partly stabilised" and "Solidification".

- Criteria for classification of waste containing certain priority pollutants (POPs). ${ }^{7}$

- Testing of waste should be in accordance with Regulation (EC) No $440 / 2008$ or other internationally recognised test methods and guidelines, unless otherwise specified in Regulation (EC) No $1272 / 2008{ }^{8}$

- The results of testing of waste shall prevail if a waste has been assessed by both a test and using concentration limits as indicated by WFD Annex III.

- Concentration limits in Annex III do not apply for metal alloys in their massive form (not contaminated with hazardous substances).

- Notes related to harmonised assessment of hazardous substances and mixtures in the CLP Annex VI that may be taken in account in the assessment.

The revised WFD Annex III defines properties that render waste hazardous and for several hazardous properties also provides substance specific limits. The purpose of the revision was to adapt hazardous waste classification system to technical and scientific progress and to bring the system in alignment with the new chemicals legislation, i.e. the CLP regulation. ${ }^{9}$

\footnotetext{
${ }^{6}$ This is also true for absolute entries but with the difference that the classification as hazardous or non-hazardous has been agreed upon in advance at EU level.

${ }^{7}$ polychlorinated dibenzo-p-dioxins and dibenzofurans (PCDD/PCDF), DDT (1,1,1-trichloro-2,2- bis (4-chlorophenyl)ethane), chlordane, hexachlorocyclohexanes (including lindane), dieldrin, endrin, heptachlor, hexaclorobenzene, chlordecone, aldrine, pentachlorobenzene, mirex, toxaphene hexabromobiphenyl and/or PCB exceeding the concentration limits indicated in Annex IV to Regulation (EC) No 850/2004 of the European Parliament and of the Council.

${ }^{8}$ Regulation (EC) No $1272 / 2008$ is the CLP regulation. In WFD Annex III a reference is made also to relevant CEN notes as appropriate for testing of waste.

${ }^{9}$ Regulation (EC) No. 1272/2008: Regulation (EC) No 1272/2008 of the European Parliament and of the council of 16 December 2008 on classification, labelling and packaging of substances and mixtures, amending and repealing Directives 67/548/EEC and 1999/45/EC, and amending Regulation (EC) No 1907/2006.
} 
The CLP also prescribes procedures for the classification of certain hazardous properties. In the future it would be useful to review all the current absolute entries in the LoW to ensure that they conform to the revised rules of classification and to document the actual assessment in relation to each HP.

Figure 1: Regulated criteria and test methods for classification of hazardous waste

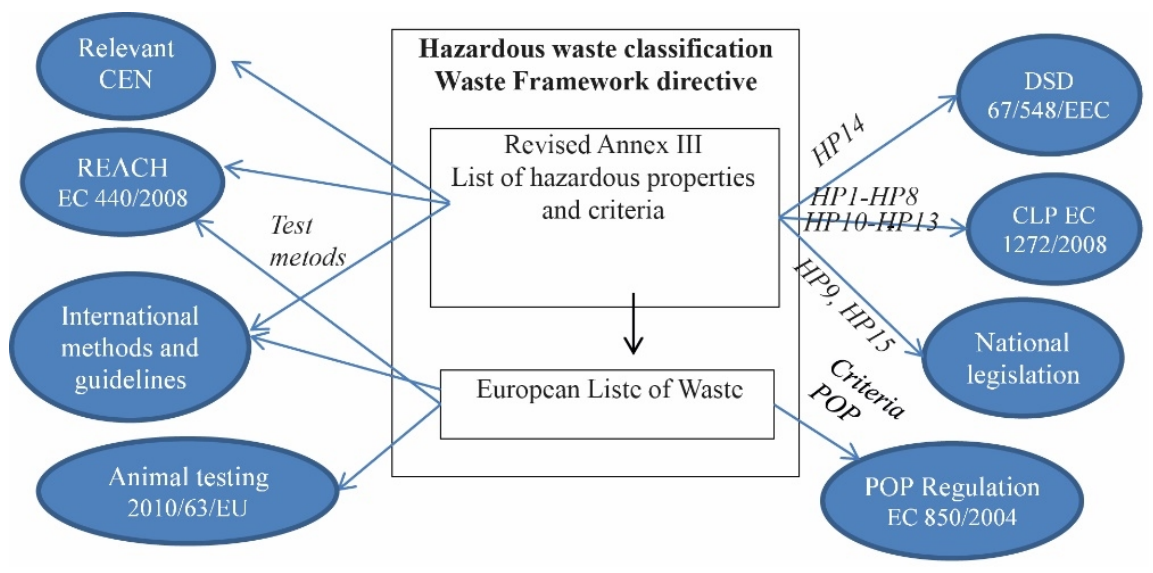

Note: $\mathrm{DSD}=$ Dangerous Substances Directive, CLP = Classification, Labelling and Packing Regulation, $\mathrm{POP}=$ Persistent Organic Pollutant (see also the list of abbreviation), CEN = European committee for standardization

\subsubsection{European List of Waste - mirror entries}

The European List of Waste is divided into 20 categories (labelled with 2 digits) based on key process (source) that generates the waste or specific waste types (e.g. Digit 20 for Municipal Wastes (Household waste and similar commercial, industrial and institutional wastes - Including separately collected fractions). The waste categories are further divided into sub-categories labelled with 4 digit codes based on processes and/or input materials used in the process. Finally each specific waste entry under each sub-category is given a specific 6 digit code and description.

The wastes in the LoW are labelled in three different ways depending on their hazard classification: 
Table 1: Types of LoW entries

\begin{tabular}{|c|c|}
\hline Entry type & Explanation \\
\hline $\begin{array}{l}\text { "absolute hazar- } \\
\text { dous entry" }\end{array}$ & $\begin{array}{l}\text { The code is marked with an asterisk }\left({ }^{*}\right) \text { and the waste is classified as hazardous waste (no } \\
\text { further assessment needed) }\end{array}$ \\
\hline "mirror entry" & $\begin{array}{l}\text { The waste is potentially hazardous or non-hazardous waste depending on a specific or gen- } \\
\text { eral reference to hazardous substances or hazardous properties. The hazard properties of } \\
\text { the waste have to be assessed prior to addressing the appropriate waste code }\end{array}$ \\
\hline $\begin{array}{l}\text { "absolute non-ha- } \\
\text { zardous entry" }\end{array}$ & The waste is classified as non-hazardous (no further assessment needed) \\
\hline
\end{tabular}

There are different kinds of hazardous mirror entries, and sometimes it is difficult to distinguish mirror entries from absolute entries. The trigger for the need to assess the hazardous properties of a waste is the specific or general reference to hazardous substances or hazardous properties in the description of the waste. In most cases the mirror entries are a pair of two (sometimes more) entries ( 6 digit codes) one hazardous and the other non-hazardous, see Table 2 example A. The hazardous entry refers to the presences of hazardous substances (general or specific) while the non-hazardous entry cross-refers to (mirrors) the hazardous entry digit code. But there are also cases where the mirror entries are un-paired i.e. there is no cross reference from the non-hazardous entry to the hazardous entry, see Table 2 example B. While the interpretation of paired mirror entries normally is easy, the interpretation of un-paired mirror entries is less straightforward and may differ in different guidance documents. Both for the paired and unpaired mirror entries, the waste holder must show that the waste does not exhibit hazardous properties related to the presence of hazardous substances prior to assigning a non-hazardous waste code. 
Table 2: Examples of mirror entries

\begin{tabular}{|c|c|}
\hline \multicolumn{2}{|c|}{ A) Paired mirror entries } \\
\hline Waste code & Name of waste \\
\hline 10 & Thermal processes \\
\hline 1001 & Wastes from power stations and other combustion plants (except 19) \\
\hline 1001 14* & bottom ash, slag and boiler dust from co-incineration containing hazardous substances \\
\hline 100115 & bottom ash, slag and boiler dust from co-incineration other than those mentioned in 100114 \\
\hline $100116^{*}$ & fly ash from co-incineration containing hazardous substances \\
\hline 100117 & fly ash from co-incineration other than those mentioned in 100116 \\
\hline \multicolumn{2}{|c|}{ B) Unpaired mirror entries ${ }^{10}$} \\
\hline Waste code & Name of waste \\
\hline 6 & Wastes from inorganic chemical processes \\
\hline 0604 & metal-containing wastes other than those mentioned in 0603 \\
\hline 0604 03* & wastes containing arsenic \\
\hline $060404^{*}$ & wastes containing mercury \\
\hline $060405^{*}$ & wastes containing other heavy metals \\
\hline 060499 & wastes not otherwise specified \\
\hline
\end{tabular}

Currently the LoW includes 842 waste entries (6 digits codes) of which about 230 are classified as absolute hazardous, 180 as mirror hazardous, 190 as mirror non-hazardous and 240 as absolute non hazardous. ${ }^{11}$

For some waste streams several codes may apply, which may have an impact on hazard classification. In such cases, the rules for selection of waste code in the LoW are to be followed.

\subsubsection{Annex III - Hazardous properties}

The Waste Framework Directive Annex III defines hazardous waste as waste that displays one or more of the hazardous properties (HPs) HP1 to HP15 (see Table 3).

For interpretation of waste status, Annex III refers for most hazardous properties directly to the hazard statement codes (HSCs) introduced in the CLP for chemical compounds or mixtures having hazardous properties. Knowledge of the HSCs and CLP rules for assessing mixtures is essential for understanding the Commission Decision. With a few exceptions, the name of each code starts with the letter $\mathrm{H}$ which is then followed by three digits. Each individual code refers to a specific hazard (physical, health or environmental) that is listed in the CLP. For example "H318" means "Causes serious

\footnotetext{
${ }^{10}$ These entries are assigned as absolute hazardous and non-hazardous in European Commission Guidance document while they are assigned as mirror entries in the UK Technical Guidance WM3.

${ }^{11}$ European Commission, Guidance document - On the definition and classification of hazardous waste,

http://ec.europa.eu/environment/waste/studies/pdf/definition\%20classification.pdf
} 
eye damage". Each hazard statement is directly linked to a specific test method and criteria for assessing the hazard property. The HSCs replace the so-called risk phrases of chemicals used in Commission Decision 2000/532/EC, as well as the repealed Directives 67/548/EEC (DSD) and 1999/45/EC (DPD) that have been replaced by the CLP. Hazard property HP 9 "Infectious" does not correspond to any properties in the CLP or harmonised criteria and has to be assessed based on national guidelines. Additionally, for HP15 "Waste capable of exhibiting a hazardous property listed above not directly displayed by the original waste" Member States may issue additional national criteria, such as assessment of leachate. However, it can be noted that the assessment of leachate is to this date not generally applied; only Austria is applying this additional criteria). These properties are not further discussed.

Waste classification is largely based on the presence of hazardous substances and thus directly linked to assessments and guidelines under the CLP. The classification of a substance (e.g. nickel carbonate) in relation to a given hazard statement is again based on intrinsic hazards, i.e. the basic properties of a substance as determined in tests regulated by the CLP or by other means designed to identify hazards. A substance having one or more hazardous properties is marked with one or more hazard statements under the CLP. Depending on the purpose, the classification of waste does not necessarily require a full assessment of all hazardous properties. If one property meets the criteria for the waste to be classified as hazardous - and the purpose is only to determine if the waste is hazardous or non-hazardous, then the waste will be classified as hazardous, even though all HPs have not been considered. However, in order to be classified as non-hazardous (or if the purpose is for example to label the waste) all HPs must be assessed, see also section 2. In line with the CLP guidelines, the waste classification does not take specific exposure scenarios (i.e. whether waste is recycled, handled by landfilling, incineration etc.) into consideration in the classification. There are, however, circumstances when a substance can be considered as not being biologically available. The extent to which bioavailability shall be taken into account may vary between different hazard properties. As for the HP14, an assessment of the bioavailability is of great importance. While a metal in the massive form is classified as non-hazardous, particulate metals (e.g. $\mathrm{Cu}$ and $\mathrm{Zn}$ powder), however, can be classified as hazardous. The boundary between massive and particulate form is generally set at $1 \mathrm{~mm}$ size.

During the revision work, several of the given HP characteristics and linked parameters have been subjected to critical discussion in the subgroup established under the TAC for waste legislation (The European 
Commission Committee for the Adaptation to Scientific and Technical Progress of EC Legislation on waste). In the Commission Regulation (EU) No 1357/2014, the criteria for HP14 were left open and a report on a study carried out by a consultant for the EU Commission has recently been published. ${ }^{12}$

In order to minimise the need for (unnecessary) testing, mixtures can be assessed based on the presences of hazardous substances. Guidelines for such assessment are given in the CLP. These assessments are either based on trigger concentrations related to the occurrence of individual hazardous substances or to the sum of hazardous substances with a specific property e.g. HP 14. The CLP also operates with cut-off values for substances where summation is applied. If a substance is present in the waste below its cutoff value, it shall not be included in any calculation of thresholds or concentration limits for classification. Wastes generally are mixtures of (numerous) substances, and this approach is implemented in Annex III with minor modifications. Application of this approach requires a quantification of all hazardous substances (species) in the waste and that the hazard classification (hazard statement) of the identified substances is available which can be a challenge. There is, however, no need to quantify non-hazardous species in the waste that do not contribute significantly in the hazard assessment. A simple overview of the classification procedure for wastes with mirror entries in the LoW is shown in Figure 2.

Figure 2: Waste classification and assessment methodology: mirror entry assessment ${ }^{13}$

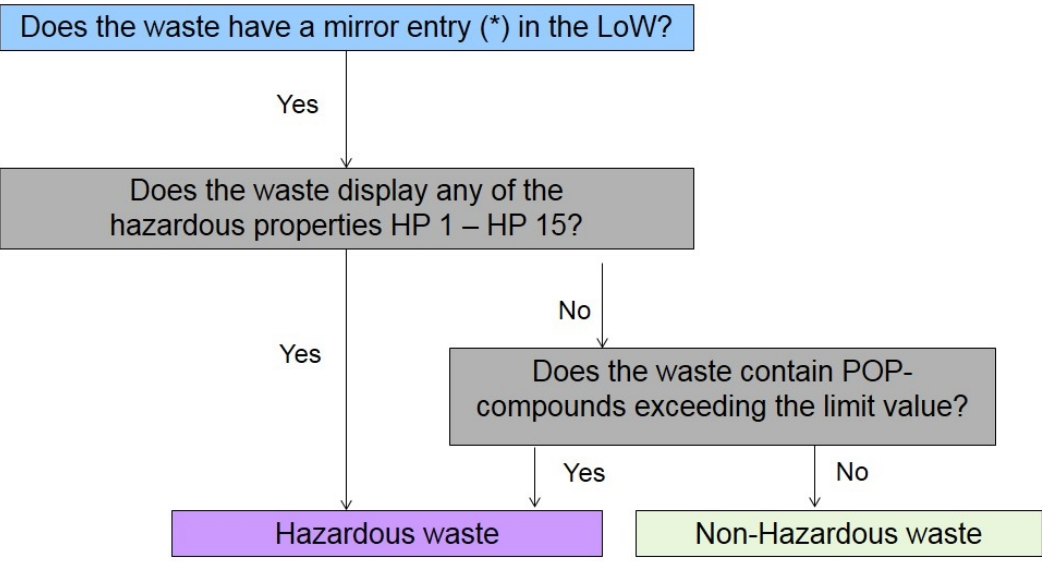

Source: ref. EU guidance study by BiPRO modified.

12 http://ec.europa.eu/environment/waste/studies/pdf/H14.pdf

${ }^{13}$ Study to develop a guidance document on the definition and classification of hazardous waste. 2015

http://ec.europa.eu/environment/waste/studies/pdf/definition\%20classification.pdf 
Table 3: Properties of waste which render it hazardous

\begin{tabular}{|c|c|c|}
\hline $\begin{array}{l}\text { Hazardous } \\
\text { Property }\end{array}$ & $\begin{array}{l}\text { Hazardous properties of Waste directive } \\
\text { Annex III }\end{array}$ & $\begin{array}{l}\text { Hazardous statement } \\
\text { codes related to the ha- } \\
\text { zardous property (EU } \\
\text { Commission Regulation } \\
\text { No. } 1357 / 2014 \text { ) }\end{array}$ \\
\hline HP 1 & $\begin{array}{l}\text { "Explosive": Wastes which are capable by chemical reaction of producing gas at } \\
\text { such a temperature and pressure and at such a speed as to cause damage to the } \\
\text { surroundings. Pyrotechnic wastes, explosive organic peroxide wastes and explosive } \\
\text { self-reactive wastes are included }\end{array}$ & $\begin{array}{l}\mathrm{H} 200-205, \mathrm{H} 240-241 \\
\mathrm{H} 280\end{array}$ \\
\hline HP 2 & $\begin{array}{l}\text { "Oxidising": Wastes which may, generally by providing oxygen, cause or con- } \\
\text { tribute to the combustion of other materials }\end{array}$ & $\mathrm{H} 270-272$ \\
\hline HP 3 & $\begin{array}{l}\text { "Flammable": } \\
\text { - Flammable liquid wastes: liquid wastes having a flash point below } 60^{\circ} \mathrm{C} \text { or } \\
\text { waste gas oil, diesel and light heating oils having a flash point }>55^{\circ} \mathrm{C} \text { and } \leq 75^{\circ} \mathrm{C} \\
\text { - flammable pyrophoric liquid and solid wastes: solid or liquid wastes which, } \\
\text { even in small quantities, are liable to ignite within five minutes after coming into } \\
\text { contact with air } \\
\text { - flammable solid wastes: solid wastes which are readily combustible or may } \\
\text { cause or contribute to fire through friction } \\
\text { - flammable gaseous wastes: gaseous wastes which are flammable in air at } 20^{\circ} \mathrm{C} \\
\text { and a standard pressure of } 101.3 \mathrm{kPa} \\
\text { - water reactive wastes: wastes which, in contact with water, emit flammable } \\
\text { gases in dangerous quantities } \\
\text { - other flammable wastes: flammable aerosols, flammable self-heating wastes, } \\
\text { flammable organic peroxides and flammable self-reactive wastes. }\end{array}$ & $\begin{array}{l}\text { H220-228, H241-242, } \\
\text { H250-252, H261, H270- } \\
272, \text { H282 }\end{array}$ \\
\hline HP 4 & $\begin{array}{l}\text { "Irritant - Skin irritation and eye damage": Wastes which on application can } \\
\text { cause skin irritation or damage to the eye }\end{array}$ & H314-315, H318-319 \\
\hline HP 5 & $\begin{array}{l}\text { "Specific Target Organ Toxicity (STOT)/ Aspiration": Wastes which can cause } \\
\text { specific target organ toxicity either from a single or repeated exposure, or } \\
\text { which cause acute toxic effects following aspiration }\end{array}$ & H304, H335, H370-373 \\
\hline HP 6 & $\begin{array}{l}\text { "Acute Toxicity": Wastes that can cause acute toxic effects following oral or } \\
\text { dermal administration, or inhalation exposure }\end{array}$ & $\begin{array}{l}\text { H30O-302, H310-312, } \\
\text { H330-332 }\end{array}$ \\
\hline HP 7 & "Carcinogenic": Wastes which induce cancer or increase its incidence & H350-351 \\
\hline HP 8 & "Corrosive": Wastes which on application can cause skin corrosion & H314 \\
\hline HP 9 & $\begin{array}{l}\text { "Infectious": Wastes containing viable micro-organisms or their toxins } \\
\text { which are known or reliably believed to cause disease in man or other living } \\
\text { organisms }\end{array}$ & $\begin{array}{l}\text { Criteria/limits in national } \\
\text { legislation. }\end{array}$ \\
\hline HP 10 & $\begin{array}{l}\text { "Toxic for reproduction": Wastes which have adverse effects on sexual func- } \\
\text { tion and fertility in adult males and females, as well as developmental toxicity } \\
\text { in the offspring }\end{array}$ & H360-361 \\
\hline HP11 & $\begin{array}{l}\text { "Mutagenic": Wastes which may cause a mutation, that is a permanent change } \\
\text { in the amount or structure of the genetic material in a cell }\end{array}$ & $\mathrm{H} 340-\mathrm{H} 341$ \\
\hline HP 12 & $\begin{array}{l}\text { "Release of an acute toxic gas": Wastes which release acute toxic gases } \\
\text { (Acute Tox.1, } 2 \text { or } 3 \text { ) in contact with water or an acid }\end{array}$ & $\begin{array}{l}\text { EUH029, EUH031 and } \\
\text { EUH032 }\end{array}$ \\
\hline
\end{tabular}




\begin{tabular}{l|ll}
$\begin{array}{l}\text { Hazardous } \\
\text { Property }\end{array}$ & $\begin{array}{l}\text { Hazardous properties of Waste directive } \\
\text { Annex III }\end{array}$ & $\begin{array}{l}\text { Hazardous statement } \\
\text { codes related to the ha- } \\
\text { zardous property (EU } \\
\text { Commission Regulation } \\
\text { No. 1357/2014) }\end{array}$ \\
HP 13 & $\begin{array}{l}\text { "Sensitising": } 14 \text { Wastes which contain one or more substances known to } \\
\text { cause sensitising effects to the skin or the respiratory organs }\end{array}$ & H317, H334 \\
HP 14 & $\begin{array}{l}\text { "Ecotoxic": Wastes which present or may present immediate or delayed risks } \\
\text { for one or more sectors of the environment. }\end{array}$ & Under review \\
HP 15 & $\begin{array}{l}\text { "Yielding another substance": Wastes capable of exhibiting a hazardous prop- } \\
\text { erty listed above not directly displayed by the original waste }\end{array}$ & $\begin{array}{l}\text { H205, EUH001, EUH019, } \\
\text { EUH044, possible addi- } \\
\text { tional criteria/limits set in }\end{array}$ \\
& & national legislation.
\end{tabular}

\subsubsection{National decision for interpretation of hazardousness}

The waste classification is complex in the case of mirror entries due to several reasons and further guidance for interpretation is needed. The interpretation requires understanding of both the CLP classification criteria and the testing of waste characteristics. The EU Commission is providing some guidance on the interpretation, but the assessment procedures (especially related to testing) will probably be decided on national level at least for the near future.

The following assessment steps are open for national decisions:

- The choice of analytical methods for quantifying the presence of elements and substances.

- The choice of approach in evaluation (especially related to speciation and classification of hazardous species).

- The choice of suitable test methods in case several methods are available (e.g. the use of pH as indicator for HP 4 and HP 8).

- Calculation methods for groups of compounds (e.g. PCB and PAH).

- The use of leaching criteria for HP 15.

- Provision of further guidance on how to take samples for assessment (use of mean values, ageing of waste, point for determination...).

- Possibilities to simplify the assessment procedure.

${ }^{14}$ As far as testing methods are available. 


\subsubsection{Existing guidance documents}

Box 1 provides information on useful guidelines published on the classification of hazardous waste and also on databases for classification of chemicals according to the hazardous statement codes.

\section{Box 1. Useful guidelines}

Commission study performed by BiPRO: Study to develop a guidance document on the definition and classification of hazardous waste. 2015.15

\section{National guidelines updated to reflect the CLP}

Both in the UK and in France guidance documents for waste classification have been published.

The documents have been used as background documents in this report. Examples of guidance documents are:

- Waste Classification: Guidance on the classification and assessment of waste. 1st edition 2015. Technical Guidance WM3.16

- Waste Hazardousness Assessment - Proposition of methods. INERIS 2013. Report prepared for Ministry of Ecology, Housing and Sustainable development. France (this document does not fully reflect the revision of Annex III to Directive 2008/98/EC). ${ }^{17}$

\section{Databases linked to REACH and the CLP}

The ECHA Classification \& Labelling Inventory database (http://echa.europa.eu/ web/guest/information-on-chemicals/cl-inventory-data base) contains classification and labelling information on notified and registered substances received from manufacturers and importers. It also includes the normative legal binding harmonised classifications in annex IV of the CLP. ECHA maintains and regularly updates the Inventory, but does not review or verify the accuracy of the information. One main aim of the inventory is to promote uniform classification of substances. However, today for many substances different classifications have been notified. Classifications derived from joint submissions to the REACH registration

\footnotetext{
15 Study to develop a guidance document on the definition and classification of hazardous waste. 2015 http://ec.europa.eu/environment/waste/studies/pdf/definition\%20classification.pdf http://ec.europa.eu/environment/waste/pdf/consult/Draft\%20guidance\%20document_09062015.pdf ${ }^{16}$ https://www.google.fi/?gfe_rd=cr\&ei=PPLGVs2VDa707gTmrImYCg\#q=technical+guidance+wm3 +waste+classification

${ }^{17}$ Hennebert P, Rebischung F. 2013. Waste Hazardousness Assessment - Proposition of methods. Report INERIS- DRC-13-136159-04172A- 69 pp. http://www.ineris.fr/centredoc/drc-13-136159-04172ahazardouswaste-assessment-f3-1379929842.pdf
} 
process are flagged. For more information on these substances, the Registered substances database (http://echa.europa.eu/en/infor-mation-on-chemicals/registered-substances) can be consulted where in-depth information on test results and risk assessment can be found.

These databases can be used as indicative information for waste classification but care must be taken when extracting information especially when different classifications have been notified.

\subsection{Legal and practical implications of waste classifications}

The waste classification has several implications. There are numerous EU regulations setting special requirements for waste defined as hazardous waste:

- Waste Framework Directive (Directive 2008/98/EC on waste).

- Scrap Metal - End of Waste Regulation (Council Regulation EU No 333/2011), glass cullet (EU Commission Regulation No 1179/2012) and copper scrap (EU Commission Regulation No 715/2013).

- Waste Shipment Regulation (Regulation EC No 1013/2006 and Regulation EU No 660/2014).

- Landfill Directive 1999/33/EC.

- Waste acceptance criteria at landfill (Council Decision 2003/33/EC).

- Industrial Emissions Directive (2010/75/EU).

- Environmental Impact Assessment Directive (85/337/EEC).

- Seveso II -Directive (Directive 96/82/EC).

- Directive on the Transport of Dangerous Goods (2008/68/EC).

- Directive on the management of waste from extractive industries (2004/35/EC (waste status to be taken into account in classification of mining waste facility as a category A facility).

Therefore changes in waste classification may set new demands in the whole waste management chain. Examples of influence: legal procedures in waste handling (permit, taxation, inspections), requirements on waste 
storage, transportation, reuse/recycling and disposal of waste (e.g. landfilling), traceability from production to final destination and ban on the mixing of hazardous waste.

Classification of waste as hazardous may in the future create conflicts with targets for resource efficiency (including Circular Economy). Recovery and recycling processes will generate new waste fractions such as process rejects and sludges from waste water treatment. The rejects from new advanced metal recovery processes contain residual metals which might be more bioavailable than they are in untreated wastes. Some of these waste fractions are potentially to be classified as hazardous. It is therefore important to collect information at an early stage on potential problems in recycling of waste materials.

\subsection{Hazardous waste amounts generated in Nordic countries}

The following text is an extract from an EEA report about hazardous waste generation in Europe. ${ }^{18}$

Every second year Eurostat collects information about hazardous and non-hazardous waste amounts generated in the member states for all sectors of economy (NACE) including households. According to Eurostat data, approximately 7 Mill. tonnes of hazardous waste were generated in 2012 in the Nordic countries (compared to approximately 105 Mill tonnes in EU-28 plus Norway, Iceland, Switzerland and Turkey). Figure 3 shows the amounts of hazardous waste produced in the Nordic countries during 2006-2012.

\footnotetext{
${ }^{18}$ Hazardous waste review in the EU - 28, Iceland, Norway, Switzerland and Turkey. Generation and treatment. June 2015 Prepared by the ETC/SCP and ETC/WMGE. Authors: Emmanuel C. Gentil, Leonidas Milios, Christian Fischer. European Topic Centre on Sustainable Consumption and Production. Report updated by: Elina Merta and Margareta Wahlström, European Topic Centre on Waste and Materials in a Green Economy.
} 
Figure 3: Total hazardous waste generated from all NACE activities, including household waste

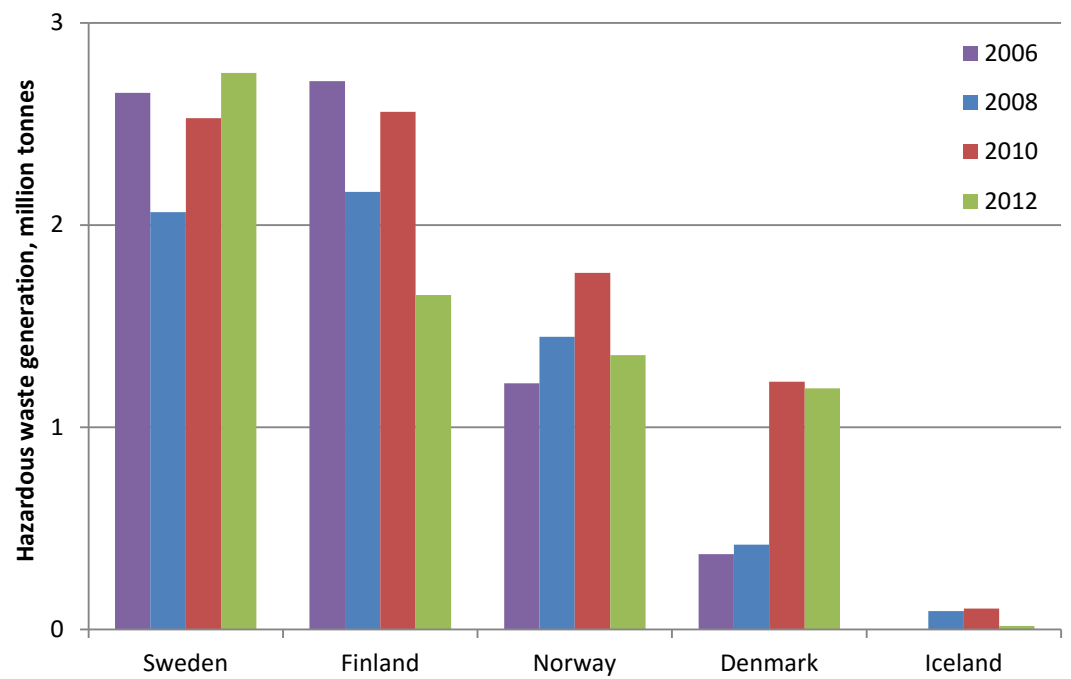

Source: Eurostat [env_wasgen], 2015.

Figure 4 illustrates the hazardousness of generated waste. This is calculated by dividing hazardous waste generation by the total waste generated by a country. The hazardousness indicator is influenced by several factors, e.g. types of industries in a country. For example, Iceland reports the highest amount of hazardous waste in the household sector (mainly waste category soils). 
Figure 4: Hazardousness calculated by dividing total hazardous waste generation by the total generated amount of waste by a country. Hazardous waste generated from all NACE activities, including household waste

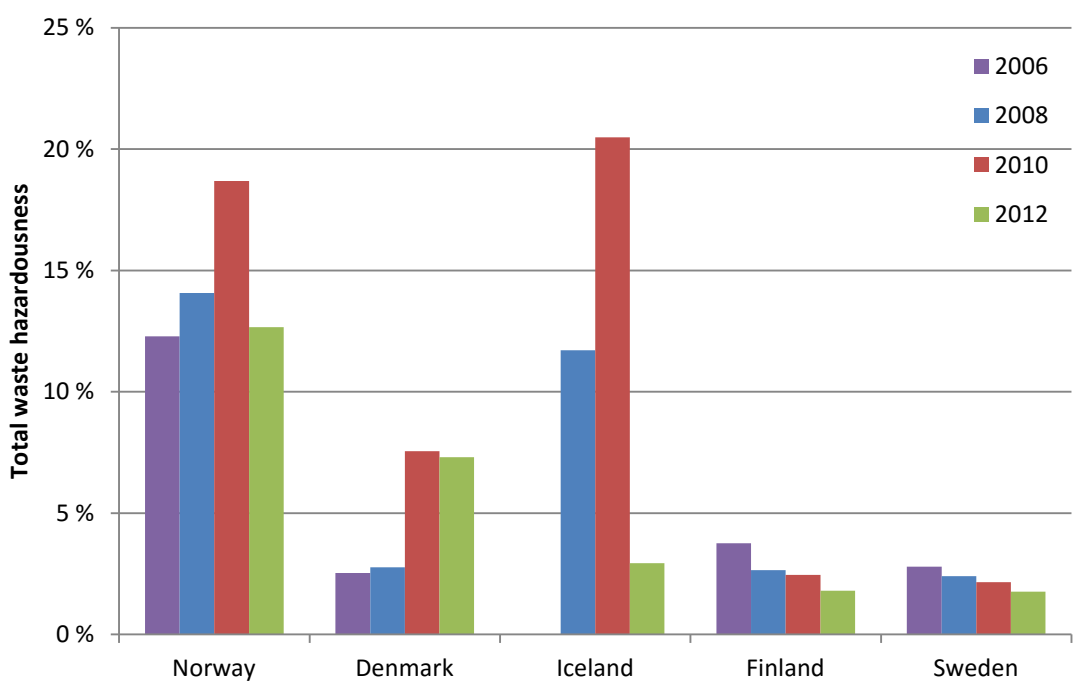

Source: Eurostat [env_wasgen], 2015.

When considering the countries that had the largest relative changes between 2006 and 2012 (ratio of 2012/2006), it is interesting to note that the change is linked to few types of hazardous waste, as summarised in Table 4 for the Nordic countries. For example, while Denmark generates a relatively small quantity of hazardous waste, it is the country with the largest increase in hazardous waste generated between 2006 and 2012 (372,892 and 1,192,750 tonnes, respectively). This is due to a change in the national reporting procedure, and the inclusion of soils classified as hazardous waste $(473,238$ tonnes in 2012$)$, not reported previously. 
Table 4: The increase or decrease of hazardous waste generation between 2006 and 2012

\begin{tabular}{|c|c|c|c|c|}
\hline Country & 2006 & 2012 & $\begin{array}{r}\text { Ratio } \\
2012 / 2006\end{array}$ & $\begin{array}{l}\text { Waste types contributing most to the increase or } \\
\text { decrease }\end{array}$ \\
\hline Denmark & 373,000 & $1,190,000$ & 3.2 & $\begin{array}{l}\text { Increase in mineral and solidified wastes, most of } \\
\text { which are soils }\end{array}$ \\
\hline Norway & $1,220,000$ & $1,360,000$ & 1.1 & $\begin{array}{l}\text { Increase in chemical and medical wastes; decreases } \\
\text { in discarded equipment and mineral and solidified } \\
\text { wastes }\end{array}$ \\
\hline Sweden & $2,650,000$ & $2,750,000$ & 1.0 & $\begin{array}{l}\text { Increase in mineral and solidified wastes; decrease } \\
\text { in discarded vehicles }\end{array}$ \\
\hline Finland & $2,710,000$ & $1,650,000$ & 0.6 & $\begin{array}{l}\text { Decreases in mineral and solidified wastes, chemical } \\
\text { and medical wastes, equipment }\end{array}$ \\
\hline Iceland ${ }^{1}$ & 90,500 & 16,800 & 0.2 & $\begin{array}{l}\text { Decrease in equipment, mineral and solidified } \\
\text { wastes }\end{array}$ \\
\hline
\end{tabular}

Note: Comparison of 2008 and 2012.

Source: See footnote 18.

It should be noted, however, that the quality of the statistics on generated and treated amounts of hazardous waste within the EU collected by Eurostat has been seriously questioned lately. There are indications that significant reporting inaccuracies and differences between reporting practices in the different Member States are at least partly responsible for the poor data quality. ${ }^{19}$

${ }^{19}$ Reichel, A., European Environment Agency: Hazardous waste generation and management figures and stitistics at the EU level. Presented at the ISWA Workshop "Hazardous Waste and Circular Economy Package", 28 January 2016, Brussesls. 


\section{Tiered procedure for hazard property assessment}

\subsection{Overview of general methodology}

In order to save efforts and in some cases compensate for lack of information about a given type of waste, it may be useful to apply a tiered approach in the hazard classification procedure.

The following stepwise procedure is recommended by the authors:

Step 1: Classification based on the European List of Waste.

Step 2: Screening at a high level to exclude non-relevant hazardous properties from further assessment.

Step 3a: Assessment of hazardous properties not eliminated in Step 2 on the basis of data on the content of elements/substances. A reasonably worst case scenario is used assuming that the total amount of a given substance is present in a hazardous form of speciation. Mainly relevant for HP4 - HP8 and HP10, HP11 and HP14. The choice of speciation and classification is preferably specific for different wastes with different origin.

Step 3b: Assessment of hazardous properties not eliminated in Step 2 based on performance of tests (HP1-HP3 and possibly other HPs).

Step 3c: Assessment of hazardous properties not eliminated in Step 2 using the principle of bridging.

Step 4: Assessment of hazardous properties not eliminated in the previous steps, based on substance content, bioavailability or leaching data and chemical speciation measurement or calculations. Evaluation of the data including data from previous steps by a weight of evidence approach leading to a final conclusion concerning the classification the waste as hazardous or non-hazardous.

The individual steps are discussed in more detail in the following. The collection of data for the assessment and strategies and methods for determination of waste composition/total content of elements/substances is discussed in Chapter 3.

If the purpose of a waste classification is merely to determine if a given waste is non-hazardous or hazardous, the assessment procedure can be discontinued (and some efforts saved) as soon as the hazard classification limit value is exceeded for one HP, even if not all HPs have been assessed. 
However, if the waste is non-hazardous, or if the purpose of the classification is e.g. to label the waste, then it will be necessary to fully assess all HPs. Also in this case, the stepwise procedure provides a useful, systematic classification methodology that may eliminate unnecessary work.

\subsection{Step 1: Classification based on the European List of Waste}

The starting point of a waste classification exercise should be the European List of Waste (LoW), i.e. the revised version of Annex III to Directive 2008/98/EC in Commission Regulation (EU) No 1357/2014. BiPRO's study for the Commission to develop an EU guidance document on the definition and classification of hazardous waste contains an annotated list of wastes where it is stated for each LoW entry if it is considered as hazardous, ${ }^{20}$ non-hazardous or a mirror entry. (see Table 4 in BiPRO's study report). However, it should be noted that there might be national deviations from this interpretation.

- If a waste is listed as an "absolute" hazardous waste in the LoW, it is always classified as hazardous, and no threshold assessment is required. An absolute hazardous entry is always marked by an asterisk $(*)$. Note that national deviations may apply.

- Similarly, if a waste is listed as an "absolute" non-hazardous entry in the LoW, that waste is always classified as non-hazardous. No threshold assessment is required. Note that national deviations may apply.

- A mirror hazardous entry (marked with an asterisk) will always have specific or general reference to hazardous substances or hazardous properties in the description of the waste. Usually, but not exclusively, it will be linked to a non-hazardous entry which provides a reference to the mirror hazardous entry (paired mirror entries). It may also be lacking any explicitly stated non-hazardous counterpart (unpaired mirror entries). Classification will require threshold assessment. If no information on the property of the waste is available the default classification should be hazardous.

${ }^{20}$ Study to develop a guidance document on the definition and classification of hazardous waste. 2015. http://ec.europa.eu/environment/waste/studies/pdf/definition\%20classification.pdf 
- A mirror non-hazardous entry will usually be explicitly linked to a mirror hazardous waste. Classification will require threshold assessment.

An absolute hazardous entry can thus be recognised by being marked with "*” and having no specific or general reference to hazardous substances or hazardous properties in the description of the waste.

An absolute non-hazardous entry can be recognised by not being marked with “*” and having no hazardous counterpart paired or un-paired.

See also the description in Section 1.2.2

\subsection{Step 2: Screening at a high level for non-applicable hazardous properties}

Step 2 is a screening process in which a high level assessment of the relevance of the hazardous properties (HP1 to HP15) to the waste in question is carried out based on knowledge of the gross characteristics and composition of the waste. No further consideration of hazardous properties which are deemed not relevant will be necessary. The HPs which are or may be relevant in relation to classification of the waste in question must be considered in the next step(s). See further Annex C in the BiPRO's study report.

Examples of HPs that can be excluded in Step 2 when classifying e.g. incinerator bottom ash are HP1: Explosive and HP2: Oxidising.

\subsection{Step 3a: Assessment of hazardous properties based on total content of substance and a worst case scenario}

In Step 3a the assessment of hazardous properties not eliminated in Step 2 is based on total content of substances. For waste, the chemical composition is generally determined and reported in terms of content of elements (e.g. $\mathrm{Cu}$ rather than $\mathrm{CuSO}_{4}$ ) for inorganic substances whereas it is more common to report the content of specific substances for organic substances. Since the criteria in the CLP are given in terms of specific substances, the chemical analysis data for inorganic substances must be recalculated from elements to specific substances according to the stoichi- 
ometry to be comparable to the hazardous limit values according to Commission Regulation No $1357 / 2014 .{ }^{21}$ In this step it is then assumed that the total content of each element considered is present solely as a reasonably critical substance for each hazard statement code under each HP. If this - together with assessment of the organic substances - does not lead to classification of the waste as hazardous in relation to a given HP, then that HP can be eliminated (with respect to classification of the waste as hazardous) when moving to the next step. This step is mainly relevant for HP4 - HP8 and HP10, HP11, HP13 and HP14.

\subsection{Step 3b: Assessment of hazardous properties based on performance of tests}

In Step 3b, assessment of hazardous properties not eliminated in Step 2 (or Step 3a) is based on the performance of tests on the waste material in question. Examples of such tests are test for oxidising properties (HP2) and flammability (HP3). This step is mainly relevant for HP1 - HP3 and possibly for other HPs.

\subsection{Step 3c: Assessment of hazardous properties based on the principle of bridging}

In Step 3c assessment of hazardous properties not eliminated in Step 2 (or 3a or 3b) may for some waste materials be based on the principle of bridging. Many by-products that are multi-constituent (e.g. reaction masses) or UVCB substances (= Substances of Unknown or Variable Composition) have been registered under REACH (see further BiPRO's study report, ${ }^{22}$ chapter B.1.3: The C\&L Inventory as research tool). These substances are often similar to or identical with waste generated from the same type of process. Information on classification of these substances can support the hazard classification of waste by using the principles of

${ }^{21}$ For a few harmonised generic group classifications the elemental content can be used directly see table 26 in Study to develop a guidance document on the definition and classification of hazardous waste. 2015. http://ec.europa.eu/environment/waste/studies/pdf/definition\%20classification.pdf

${ }^{22}$ Study to develop a guidance document on the definition and classification of hazardous waste. 2015.

http://ec.europa.eu/environment/waste/studies/pdf/definition\%20classification.pdf 
substance categorisation (CLP guidance p. 60). ${ }^{23}$ Read-across and grouping can be applied provided that these substances have physico-chemical, human health, and environmental properties that are expected to be similar to the properties of the waste.

NB: Steps 3a, 3b and 3c generally apply to different waste materials and may be selected based on the type of waste to be classified.

\subsection{Step 4: Assessment of hazardous properties based on substance content, leaching data and chemical speciation}

In Step 4, assessment of hazardous properties not eliminated (as classifying the waste in question non-hazardous) in the previous steps is based on substance content, additional testing and chemical speciation measurements and/or calculations/modelling. Such an assessment is preferably performed by applying a weight of evidence approach supported by expert judgment. Information generated in this step generally requires advanced measurement and testing methods. A joint assessment for several waste holders sharing the same process and raw material could be valid in this step.

${ }^{23}$ ECHA, 2015. European Chemicals Agency, Classification \& Labelling. Guidance on the Application of the CLP Criteria. Guidance to Regulation (EC) No 1272/2008 on classification, labelling and packaging (CLP) of substances and mixtures. Version 4.1. June 2015. Accessible from: http://echa.europa.eu/documents/10162/13562/

clp_en.pdf 


\section{Tools and methods for data procurement}

\subsection{Requirements set in the CLP regulation (1272/2008)}

The revised Annex III to the WFD (Regulation EC 1357/2014) on properties of waste which render it hazardous and the European List of Waste (LoW), relates to the classification approach for mixtures in the CLP. For test methods references are made to regulations related to REACH and to other relevant CEN methods or other internationally recognised test methods and guidelines. ${ }^{24}$ This means that the revised Annex III and LoW refer to a large selection of methods provided by CLP and other guidance documents (e.g. CEN methods) instead of specifying exactly which methods should be used in a given situation. The LoW further specifies that actual test results for a given waste have priority over results from limit values and calculation methods given in Annex III of the WFD. ${ }^{25}$ Such test data should be related to the specific hazard statement code under examination and in accordance with appropriate test methods for that hazard statement code.

Almost all hazardous properties (with exception for HP1-3, HP9, HP 12 and HP15) can be assessed based on the concentration of hazardous substances in the waste. Animal testing mentioned in REACH is not appropriate for waste classification. Alternative test methods have been developed by European Joint Research Centre (JRC). ${ }^{26}$ The European standardisation organisation CEN has also developed or is developing test methods for some properties (HP3, HP 4/8, HP12).

The revised Annex III to WFD and the CLP provide criteria in percentages as an expression of the concentration of a certain element or compound, but without specifying the base for the percentage calculation. It

\footnotetext{
${ }^{24}$ Council Regulation (EC) No 440/2008 of 30 May 2008 laying down test methods pursuant to Regulation (EC) No 1907/2006 of the European Parliament and of the Council on the Registration, Evaluation, Authorisation and Restriction of Chemicals (REACH) (OJ L 142, 31.5.2008, p. 1).

${ }^{25}$ Commission Decision 2014/955/EU of 18 December 2014 amending Decision 2000/532/EC on the list of waste pursuant to Directive 2008/98/EC of the European Parliament and of the Council.

${ }^{26}$ https://eurl-ecvam.jrc.ec.europa.eu/
} 
is, in particular, not directly specified whether the percentages refer to wet weight or dry weight for solid wastes or sludges. For some waste materials such as aqueous sludges this can give rise to uncertainties in the classification and challenges in sampling, pre-treatment and chemical analysis of samples. Since chemical analyses of wastes are typically performed on dry (or dried) matter, the results, which are usually expressed in relation to dry matter, may need to be recalculated to wet matter (the original state of the waste), using the original moisture content of the waste, if that is required for assessment against HP criteria. The study report from BiPRO addresses this issue (section 3.2.2) and states that this should be done. ${ }^{27}$ They claim that the limit values listed in Annex III to the revised WFD refer to the state of the waste at the time of classification. However, that could be a matter of debate or interpretation. BiPRO also points out that dilution for the purpose of influencing the classification is not allowed (Article 7 (4) of the WFD), which indirectly points at an inherent risk of reporting only in terms of wet material. Some (national/Nordic) guidance would be useful on this issue, for example a requirement to report results both in terms of dry matter and at the original moisture content for solid materials. This would enable the competent authorities to make their own assessment of the credibility of a reported content of water in a given solid waste. A more technical issue would be what to do with the water content if a sludge settles after sampling? The aqueous phase may contain substances that would follow the sludge when it is managed. Should the water be decanted off and analysed separately? It is recommended that this and other issues associated with determination of the content of substances are looked into in more detail than could be done in the study report produced by BiPRO. The CLP criteria refer to the relevant substances of a mixture measured in percentages on the basis of mass for solids, liquids and dusts and on the basis of volume for gases, ${ }^{28}$ but this does not provide any clarification of the above mentioned issues.

The following chapters focus on tools and methods for assessment of HP4/HP8/HP14.

${ }^{27}$ Study to develop a guidance document on the definition and classification of hazardous waste. 2015. http://ec.europa.eu/environment/waste/studies/pdf/definition\%20classification.pdf

${ }^{28}$ Inert substance that does not have an impact on then classification (e.g. water) does not have to be assessed. 


\subsection{Determination of substances in waste}

A variety of chemical analysis techniques are available for determination of individual elements and substances. Chemical analyses of waste are typically reported as total concentrations of elements or substances in $\mathrm{mg} / \mathrm{kg}$ and do not show the speciation, i.e. the chemical form in which they are present in a specific matrix. There are no guidelines on the chemical analysis or speciation of substances in mixtures in the CLP or the CLP Guidance. It is a field that must be developed under the waste legislation.

As stated previously, hazard classification criteria are set for certain substances/compounds and not for total amount of certain elements in a specific matrix material. When performing the hazard assessment it is therefore crucial that this differentiation between different substance/species (e.g. $\mathrm{Zn}(\mathrm{s})$ and $\mathrm{ZnCl}_{2}$ ) can be made. For inorganic and many organic compounds in waste materials this information is usually not obtained, nor available from conventional and commercially available chemical analysis, which in practise leads one to use worst case approaches in relation of the speciation and hazardousness with the consequence of overestimating the hazard of the waste. In the worst case scenario the total content of an analysed element is assumed to be present in the waste matrix in a chemical form (species) that is considered worst case, but potentially plausible in relation to e.g. waste (see also section 2.4). If the concentration of the specific species or the sum of concentrations of the specific species is below the relevant concentration limits when applying the Annex III summation formulas for mixtures, this will not trigger a classification as hazardous waste. For some elements generic and harmonised classifications are available in Annex VI to the CLP given as the percentages by weight of certain trace elements calculated with reference to the total weight. ${ }^{29}$ These can serve as input for reasonable worst case assessments. Many lack, however, a complete classification of the environmental hazards.

In analysis of total content, element concentrations are determined without regard to chemical speciation. Concentrations are given as pure elements while in fact they are almost always bound in chemical compounds with different states of oxidation, availability and toxicity. This is consequently highly significant from a hazard assessment point of view. For example, the element chromium is found as chromium (III) as well as chromium (VI). While chromium (III) is benign, the latter is toxic at low concentrations and requires a dedicated analytical technique.

29 These entries for groups of inorganic substances are assigned a note (Note 1) in annex VI to CLP. 


\subsubsection{Chemical analysis of inorganics}

A variety of chemical analysis techniques are available for determination of composition and characterisation of individual inorganic compounds and elements.

\section{Use of digestion methods}

Classical wet chemical analysis (digestion followed by chemical analysis) for determination of total elemental content is always important, because many hazardous elements typically sequestered as minor constituents (trace elements) and their presence may not be apparent from purely instrumental analysis methods. The measurement is more or less dependent on the digestion and extraction of the matrix to a liquid phase that is analysed.

The most commonly used multi-element analytical methods are inductively coupled plasma-atomic emission spectroscopy (ICP-AES) and inductively coupled plasma-mass spectrometry (ICP-MS). Detection limits by ICP-MS are orders of magnitude lower than detection limits for other methods, so very low concentrations of elements can be measured by this method and it is increasingly becoming the method of choice for trace element analysis of environmental samples.

Both CEN (European Committee for standardisation) and U.S. EPA (Environmental Protection Agency) (if no appropriate CEN methods available) have standardised test methods for analysis of total content in different matrices. They all include information on quality control, choosing the correct procedure, and sampling considerations as well as protocols for physical and chemical analysis of inorganic and organic analytes. For example, the following methods are prescribed in EU legislation for assessment of waste in relation to landfilling:

- EN 13656: Characterization Of Waste - Microwave Assisted Digestion With Hydrofluoric (HF), Nitric (HNO3), And Hydrochloric ( $\mathrm{HCl})$ Acid Mixture For Subsequent Determination of Elements.

- EN 13657: Sludge, treated biowaste and soil -digestion for the extraction of the aqua regia soluble fraction of trace elements.

It should be noted that whereas EN 13656 usually provides true total contents of e.g. trace elements/metals, EN 13657 does not provide a full digestion of silicate-based minerals in which some of the content of trace elements/metals may be incorporated. The results are therefore not necessarily true totals (EN 13657 is often referred to as a "partial digestion 
method") or "pseudo total". The new classification rules do not specify whether true totals are required or whether determination of substances after partial digestion (which is commonly used in waste legislation in the Nordic countries) can be used. This is less important in the chemicals legislation because it generally concerns fairly pure and often single substances.

\section{Use of non-destructive methods for speciation of inorganics}

The combination of mineralogical data and geochemical modelling is an approach that has been used to assess speciation in complex waste materials such as ashes and polluted soils. Characterisation of solids for mineralogical and speciation purposes typically includes, besides visual microscopic examination, $x$-ray fluorescence (XRF), x-ray diffraction (XRD), scanning electron microscopy (SEM EDS), and in some cases, electron probe microanalysis (EPMA), and X-ray Absorption Spectroscopy (XAS). All these instrumental methods depend on fundamental principles involving interactions between electron beams and $\mathrm{x}$-rays with samples. Knowing in which mineral a substance occurs will, in most cases, indicate its chemical form (e.g. mineralogical speciation). This will usually provide a good indication of the presence of elements in higher concentrations, while trace elements can be hidden as adsorbed, ion exchanged or substituted atoms, or occur in the form of small quantities of separate minerals. These methods often require special expertise and are generally not readily available at consultant laboratories or have poor performance for analysis of trace elements. An overview of some of these instrumental methods is given in Table 5 . 
Table 5: Typical instrumental methods used in mineralogical characterisation

\begin{tabular}{|c|c|}
\hline Method & Information obtained and remarks \\
\hline X-ray diffraction (XRD) & $\begin{array}{l}\text { Identification of minerals / compounds } \\
\text { Information on the relative abundance of a compound in a mixture } \\
\text { Detection limit } \sim 2 \% \text { of sample for mixed materials } \\
\text { Provides an unambiguous mineral determination, if access to a stand- } \\
\text { ard reference file of inorganic compounds (d-spacings, } h k / s \text { ) } \\
\text { Powder samples of tenths of a gram of material }\end{array}$ \\
\hline Micro X-ray fluorescence (XRF) & Mapping of elemental composition / minerals \\
\hline Scanning electron microscopy (SEM) & $\begin{array}{l}\text { Crystal shape, size, and texture determination, qualitative or semi- } \\
\text { quantitative compositional information of a surface }\end{array}$ \\
\hline $\begin{array}{l}\text { Electron probe microanalysis (EPMA) / } \\
\text { electron microprobe (EMP) }\end{array}$ & $\begin{array}{l}\text { Quantitative spot chemical analyses of the major and minor elements } \\
\text { in a mineral (cf. SEM) }\end{array}$ \\
\hline X-ray Absorption Spectroscopy (XAS) & $\begin{array}{l}\text { Determination of the local geometric and/or electronic structure } \\
\text { of matter }\end{array}$ \\
\hline $\begin{array}{l}\text { X-ray photoelectron spectroscopy } \\
\text { (XPS) / Electron Spectroscopy for Che- } \\
\text { mical Analysis (ESCA) }\end{array}$ & Elemental composition of the surface (top 1-10 nm) \\
\hline
\end{tabular}

\subsubsection{Aspects related to the analysis of POPs-PCB as an example}

The chemical analysis of organic substances in waste will not in general be discussed in this context. However, various aspects related to the assessment of the content of one group of organic substances, PCBs, and the relation of analytical results to hazardous waste limit values will be discussed specifically in this section. PCBs have a widespread presence in many waste materials, they belong to the Persistent Organic Pollutants (POPs) and are mentioned specifically in the LoW. They have created some confusion concerning definitions, analytical methods, and interpretation and application of analytical results. 


\section{The POP Regulation}

Persistent Organic Pollutants (POPs) are organic chemical substances, that is, they are carbon-based. They possess a particular combination of physical and chemical properties such that, once released into the environment, they

- remain intact for exceptionally long periods of time (many years)

- become widely distributed throughout the environment as a result of natural processes involving soil, water and, most notably, air

- accumulate in the fatty tissue of living organisms including humans, and are found at higher concentrations at higher levels in the food chain

- $\quad$ are toxic to both humans and wildlife.

In the revised LoW it is stated that wastes containing certain Persistent Organic Pollutants (POP) listed in the Regulation No 850/2004 and exceeding the concentration limits given in annex IV of EU Regulation No $756 / 2010$ shall be classified as hazardous wastes (see Table 6). Other POP substances than these specifically mentioned substances in the LoW are assessed against the concentration limits given for hazardous properties in the revised Annex III. 


\begin{tabular}{|c|c|c|c|}
\hline $\begin{array}{l}\text { Substances/substances groups classi- } \\
\text { fied as POP substances in regulation }\end{array}$ & POP Regulation & $\begin{array}{l}\text { Concentration } \\
\text { limit value }\end{array}$ & Reference \\
\hline $\begin{array}{l}\text { Polychlorinated dibenzo-p-dioxins and } \\
\text { dibenzofurans (PCDD/PCDF) }\end{array}$ & EU Regulation No 850/2004 & $15 \mu \mathrm{g} / \mathrm{kg}^{30}$ & \multirow{15}{*}{$\begin{array}{l}\text { Substance specific } \\
\text { limit values given in } \\
\text { the Commission Deci- } \\
\text { sion (2014/955/EU) }\end{array}$} \\
\hline Polychlorinated Biphenyls (PCB) & EU Regulation No 850/2004 & $50 \mathrm{mg} / \mathrm{kg}$ & \\
\hline Aldrin & EU Regulation No 850/2004 & $50 \mathrm{mg} / \mathrm{kg}$ & \\
\hline Chlordane & EU Regulation No 850/2004 & $50 \mathrm{mg} / \mathrm{kg}$ & \\
\hline Dieldrin & EU Regulation No 850/2004 & $50 \mathrm{mg} / \mathrm{kg}$ & \\
\hline Endrin & EU Regulation No 850/2004 & $50 \mathrm{mg} / \mathrm{kg}$ & \\
\hline $\begin{array}{l}\text { DDT (1,1,1-trichloro-2,2-bis } \\
\text { (4-chlorophenyl)ethane) }\end{array}$ & EU Regulation No 850/2004 & $50 \mathrm{mg} / \mathrm{kg}$ & \\
\hline Heptachlor & EU Regulation No 850/2004 & $50 \mathrm{mg} / \mathrm{kg}$ & \\
\hline Chlordecone & EU Regulation No 850/2004 & $50 \mathrm{mg} / \mathrm{kg}$ & \\
\hline Mirex & EU Regulation No 850/2004 & $50 \mathrm{mg} / \mathrm{kg}$ & \\
\hline Toxaphene & EU Regulation No 850/2004 & $50 \mathrm{mg} / \mathrm{kg}$ & \\
\hline Pentachlorobenzene & EU Regulation No 850/2004 & $50 \mathrm{mg} / \mathrm{kg}$ & \\
\hline Hexachlorobenzene & EU Regulation No 850/2004 & $50 \mathrm{mg} / \mathrm{kg}$ & \\
\hline Hexabromobiphenyl & EU Regulation No 850/2004 & $50 \mathrm{mg} / \mathrm{kg}$ & \\
\hline $\begin{array}{l}\text { Hexachlorocyclohexanes, including } \\
\text { lindane (gamma-HCH) }\end{array}$ & EU Regulation No 850/2004 & $50 \mathrm{mg} / \mathrm{kg}$ & \\
\hline $\begin{array}{l}\text { Pentabromodiphenyl ether (incl. tetra- } \\
\text { and pentabromodiphenyl ether) }\end{array}$ & Regulation EU No 756/2010 & \multirow{7}{*}{$\begin{array}{l}\text { The concentra- } \\
\text { tion limit for } \\
\text { the hazardous } \\
\text { properties (HP) } \\
\text { applies. Note! } \\
\text { the limit values } \\
\text { for several sub- } \\
\text { stances are de- } \\
\text { pendent on HP } \\
14 \text { (currently } \\
\text { open) }\end{array}$} & \multirow{7}{*}{$\begin{array}{l}\text { Commission } \\
\text { Regulation (EU) } \\
\text { No. 1357/2014 }\end{array}$} \\
\hline $\begin{array}{l}\text { Octabromodiphenyl ether (incl. Hexa- } \\
\text { and heptabromodiphenyl ethers) }\end{array}$ & Regulation EU No 756/2010 & & \\
\hline $\begin{array}{l}\text { Perfluorooctane sulfonic acid and its } \\
\text { derivatives (PFOS) }\end{array}$ & Regulation EU No 756/2010 & & \\
\hline Endosulfan & $\begin{array}{l}\text { Regulation EU No } \\
1342 / 2014\end{array}$ & & \\
\hline Hexachlorobutadiene & $\begin{array}{l}\text { Regulation EU No } \\
1342 / 2014\end{array}$ & & \\
\hline Polychlorinated naphthalenes & $\begin{array}{l}\text { Regulation EU No } \\
1342 / 2014\end{array}$ & & \\
\hline $\begin{array}{l}\text { Alkanes } \mathrm{C} 10-\mathrm{C} 13 \text {, chloro (short-chain } \\
\text { chlorinated paraffins) (SCCPs) }\end{array}$ & $\begin{array}{l}\text { Regulation EU No } \\
1342 / 2014\end{array}$ & & \\
\hline
\end{tabular}

\section{PCBs}

Polychlorinated biphenyls (PCBs), with the chemical formula of $\mathrm{C}_{12} \mathrm{H}_{10} \mathrm{xClx}$, are a group of synthetic chlorinated organic compounds that are of public health concern because of their persistence in the environment and their potential cancer-causing and endocrine-disruptive effects. There are 209 configurations of organochlorides, called congeners, with 1 to 10 chlorine atoms of varying toxicity, and 130 of these different PCB arrangements and

30 The limit is calculated as PCDD and PCDF according to the toxic equivalency factors (TEFs) as indicated in Regulation (EC) No 850/2004. 
orientations were used commercially (but are now banned almost worldwide). As PCBs are measured in several waste matrices, it is necessary for classification purposes, that the methods applied are comparable and making use of the same principles and instrumentation. Furthermore the quantification should be based on a common understanding on relevant congeners and their summation.

EU legislation is not very precise with regards to limit values for content of PCB in waste. The problem is apparent in the CLP where the substance simply is referred to as "polychlorobiphenyls, ${ }^{31}$ PCB", setting a limit value on content of $0.005 \%$ ( $50 \mathrm{mg} / \mathrm{kg}$ ) for content that will render a waste hazardous, not mentioning the fact that PCB as mentioned above is a group name for 209 different congeners. Also one of the predecessors to the CLP - the DSD, ${ }^{32}$ Annex 1 - refers to PCBs as a single substance. In the POP Regulation there is a reference to the measurement of the content of PCBs: ${ }^{33}$ "Where applicable, the calculation method laid down in European standards EN 12766-1 and EN 12766-2 shall be applied". These standards which refer to determination of PCB in petroleum products and used oils (and not in solid waste) prescribe two methods for the calculation of the PCB content: 1): Determine them all analytically and sum them (that is a very precise but also very tedious and expensive procedure that is never carried out in practice); 2): Determine the sum of 6 congeners PCB 28, 52, 101, 153, 138 and 180 and multiply the result by 5 to get an estimate of the total content of PCB. The Council Decision on waste acceptance procedures and criteria associated with the Landfill Directive specifies under limit values on content of PCB in in section 2.1.2.2 only "PCBs (polychlorinated biphenyls, 7 congeners)" and a limit value, ${ }^{34}$ not mentioning any factor. ${ }^{35}$ The standard EN 15308 developed by CEN/TC 292 for use e.g. in Council Decision 2002/33/EC specifies the determination of 7 congeners (PCB 28, 52, 101, $118,138,153$ and 180) but does not mention any factor or how to estimate the total content of PCB, and it is not clear whether the limit values for PCB given in Council Decision 2003/33/EC refer to the sum of the seven specified congeners or to the total content of PCBs. It is therefore important that

\footnotetext{
31 Regulation (EC) No. 1272/2008 of the European Parliament and of the Council of 16 December 2008 on classification, labelling and packaging of substances and mixtures.

32 Directive $67 / 548 /$ EEC on the approximation of the laws, regulations and administrative provisions relating to the classification, packaging and labelling of dangerous substances (including numerous updates of Annex 1 which is currently included in the CLP as Table 1.2).

${ }^{33}$ Commission Regulation (EC) No. 756/2010 of 24 August 2010 amending Regulation (EC) No. 850/2004 of the European Parliament and of the Council on persistent organic pollutants as regards Annexes IV and V.

34 Council Decision 2003/33/EC of 19 December 2002 on criteria and procedures for the acceptance of waste at landfills pursuant to Article 16 of and Annex II to Directive 1999/31/EC.

35 Council Directive 1999/31/EC of 26 April 1999 on the landfill of waste.
} 
any criteria set on the content of PCB specify both the congeners to be measured and the factor to be applied to estimate the total content corresponding to a criterion. Alternatively, the criterion (properly adjusted) could refer to the sum of the congeners to be measured.

It is interesting to note that an earlier draft version of Commission Decision 2014/955/EU (the revision of the LoW) from 2012 included the following clause under Definitions: "PCB shall be defined as in Article 2 of Directive 96/59/EC. ${ }^{36}$ The PCB content shall be measured as the sum of the PCB congeners $28,52,101,118,138,153$, and 180 multiplied by 5 for general estimation of the total PCB content, considering non-analysed congeners." In the current, final version of Commission Decision 2014/955/EU this text has been changed to: "polychlorinated biphenyls and polychlorinated terphenyls (PCBs) means PCBs as defined in Article 2(a) of Council Directive 96/59/EC" (which does not bring any clarification).

As a result of this negligence, the calculation and interpretation of the content of "PCB" in waste and in particular the analytical results that are compared to limit values for PCB vary significantly between EU Member States. As some countries compare the sum of the content of the 7 congeners directly e.g. to the hazard limit value of $50 \mathrm{mg} / \mathrm{kg}$ and other countries compare the sum of the 7 congeners multiplied by 5 , the definition of whether or not a given waste is rendered hazardous by its content of PCB may vary by a factor of 5 from one country to another.

The Finnish ${ }^{37}$ and the Danish ${ }^{38}$ legislation or guidelines specify that the sum of the 7 congeners shown in Table 7 shall be multiplied by a factor of 5 to provide an estimate of the total content of PCB in a waste material.

Table 7: The 7 PCB congeners to be summed and multiplied by 5 to provide an estimate of the total content of PCB

\begin{tabular}{ll} 
Congener & Compound \\
\hline & \\
52 & $2,4,4^{\prime}$-trichlorobiphenyl \\
101 & $2,2^{\prime}, 5,5^{\prime}$-tetrachlorobiphenyl \\
118 & $2,2^{\prime}, 4,5,5^{\prime}$-pentachlorobiphenyl \\
138 & $2,3^{\prime}, 4,4^{\prime}, 5$-pentachlorobiphenyl \\
153 & $2,2^{\prime}, 3,4,4^{\prime} 5^{\prime}$-hexachloroibiphenyl \\
180 & $2,2^{\prime}, 4,4^{\prime}, 5,5^{\prime}$-hexachlorobiphenyl \\
& $2,2^{\prime}, 3,4,4^{\prime}, 5,5^{\prime}$-heptachlorobiphenyl \\
\hline
\end{tabular}

${ }^{36}$ Council Directive 96/59/EC of 16 September 1996 on the disposal of polychlorinated biphenyls and polychlorinated terphenyls (PCB/PCT).

${ }^{37} \mathrm{http}: / /$ www.ymparisto.fi/fi-FI/Kulutus_ja_tuotanto/Lausuntopyynto_jatteiden_vaaraominaisuuk\% $2833998 \% 29$

38 Miljøministeriet/Miljøstyrelsen: Bekendtgørelse nr. 1049 af 28. august 2013 om deponeringsanlæg. 
In Sweden the default adjustment factor of 5 have been implemented when developing guideline values for soil remediation. That is, guideline values are adjusted to take into account that analyses of PCB (e.g. in terms of $\mathrm{PCB}_{7}$ ) only represents a fraction of the total PCB-content.

\subsection{Speciation of substances by geochemical modelling}

Since it is difficult to actually determine (by typical chemical analysis) whether specific compounds and minerals are actually present in the waste, there might be a need for more specialised analysis, tests and/or modelling, especially if the worst case approach triggers a classification as hazardous waste. The combination of mineralogical data, water quality data and modelling has been used for a variety of waste matrixes.

The release of substances from a solid material is often controlled by (geo)chemical mechanisms, such as solubility of minerals/salts, sorption to reactive mineral and organic surfaces and complexation to (in)organic ligands. These fundamental processes dictating the leaching can be modelled using appropriate leaching data and speciation models. The combination of especially data from the $\mathrm{pH}$ dependence leaching and subsequent multi-elemental chemical speciation modelling is one approach to obtain a better assessment of whether or not relevant compounds are present in significant amounts, and if they are, also to obtain a better estimate of the concentration levels at which they can occur.

The $\mathrm{pH}$ dependence leaching test (performed according to EN 14997 and EN 14429) provides information on the leaching of relevant substances at various $\mathrm{pH}$ values. Samples of waste are subject to leaching at different $\mathrm{pH}$ values typically in the range of $\mathrm{pH} 2-12$. Substances not available in the range of $\mathrm{pH} 2-12$ (i.e. not leached in this $\mathrm{pH}$-range or a more narrow range) are considered not being biologically available for e.g. ashes.

However, the above mentioned approach of leaching and subsequent multi-elemental chemical speciation modelling is only suitable for inorganics (primarily metals and metalloids). Furthermore, speciation modelling requires extensive data input and calibration, experience and knowledge and is depending on the model, e.g. LeachXS/Orchestra (and the species included in the linked databases) being used.

Information from the leaching test (substance concentration in the eluate, relevant $\mathrm{pH}$ range etc.) are subsequently used in speciation modelling. From the substances present, their concentration and the relevant 
$\mathrm{pH}$ value, and knowledge of the substances solubility/release under the specific conditions, the type and the speciation in the eluate can be estimated. Such information can be used to support hazard assessments at specific test conditions. However most of the experience in geochemical modelling up till now has been generated at test conditions with liquid to solid ratio $(\mathrm{L} / \mathrm{S})$ at $10 \mathrm{~L} / \mathrm{kg}$ which is not always relevant for hazard assessment (e.g it does not represent the testing conditions for assessment of ecotoxic properties in CLP test methods). Extrapolation to test conditions relevant for hazard assessment of waste is still uncertain and requires additional laboratory support, see section 5 .

It must be stressed that geochemical modelling of leaching experiments cannot be used to assess the composition of trace elements of the original waste. Geochemical modelling calculates the chemical equilibrium of trace elements in relation to the waste matrix under the specific test conditions which may differ substantially from the waste's original composition prior testing. It may, however, be used to assess whether or not a specific mineral (substance) of interest controlling the solubility of a given element is likely to be present in a given type of waste. Such assessments should to the extent possible be supported by other measurements such as, non-destructive methods for speciation (see above). 


\section{The use of alkali reserve- method for determination of Hazard properties "irritant" (HP4) and "corrosive" (HP8)}

This chapter addresses the applicability of the alkali-reserve method on selected waste streams related to the hazardous properties HP4 irritant and HP8 corrosive. Also other test methods given for chemicals can be used, if applicable (see chapter 3 and reports on methods for chemicals available from ECHA website). ${ }^{39}$

\subsection{Approach for determination of HP4/HP8 properties}

The limit values given in the revised Annex III to the WFD are based on the substances present in the waste and having the hazard statement codes listed (see Table 3). In the assessment of HP4/HP8 properties also the summation rules apply. Where a substance is present in the waste below its cut-off value, it shall not be included in comparisons to limits. The criteria for a hazard property vary from $1 \%$ to $20 \%$ depending of the hazard statement code for the substances of concern.

Methods for determination of specific elements are discussed in chapter 3. In a worst case approach the elements are assumed to occur as critical substances having irritant or corrosive properties. For example alkali metals and earth alkali metals are assumed to occur as oxides and hydroxides causing alkalinity (e.g. calcium oxide and hydroxide). Such an approach gravely overestimates the hazardousness e.g. when Ca is present as limestone $\left(\mathrm{CaCO}_{3}\right)$ rather than as lime $(\mathrm{CaO})$.

39 Guidance on the Application of the CLP Criteria. Version 4.1. European Chemicals Agency. June 2015. https://echa.europa.eu/documents/10162/13562/clp_en.pdf 
For many waste materials the content of calcium oxide and calcium hydroxide is of special concern. Calcium oxide and calcium hydroxide are irritant or corrosive depending on the concentrations. CEN has published some methods for determination of free calcium oxide $(\mathrm{CaO})$ in certain matrices (e.g. fly ash, fertilizer, cement), but generally these methods are not giving results for all compounds (oxides, hydroxides) to be included in the comparisons.

Measurement of $\mathrm{pH}$ of the waste was mentioned in an earlier draft of the Commission Decision revising Annex III to the WFD as one parameter to be used in the evaluation of hazardous waste properties related to waste classification, but the use of $\mathrm{pH}$ was not included in the final version. As seen in CLP legislation, the properties corrosive and irritant are linked to the $\mathrm{pH}$ of the materials. Especially if the waste is assumed to contain several compounds causing the alkalinity or acidity, the use of $\mathrm{pH}$ is practical, taking into account several compounds. The CLP states that: "3.2.3.3.4.2 For mixtures containing strong acids or bases the $\mathrm{pH}$ shall be used as a classification criterion (see paragraph 3.2.3.1.2) since $\mathrm{pH}$ is a better indicator of corrosion than the concentration limits of Table 3.2.3". It is also presented in the UK guideline for waste classification as a screening test to determine if the waste is hazardous and thus avoid expensive testing. ${ }^{40}$ - However, according to the UK guideline, the determination of $\mathrm{pH}$ or acid/alkali reserve alone should not be used to exonerate waste from classification as Corrosive or Irritant, because the waste may also contain other substances (e.g. nickel carbonate) having hazard statement codes falling under HP4/HP8. If the presence of such substances (where HP4/HP8 properties are not linked to $\mathrm{pH}$ ) could be ruled out based on a conservative assessment (e.g. using the approach presented in section 2.4 step 3a) the $\mathrm{pH}$ or acid/alkali reserve test method would be adequate for testing (e.g. ashes). If this is not possible, so-called in vitro tests proposed by UK can be used for other substances than bases or acids with hazard statement codes falling under HP 4/HP8 (see further 4.3).

${ }^{40}$ Guidance on the classification and assessment of waste (1st edition 2015). Technical Guidance WM3 https://www.google.fi/?gfe_rd=cr\&ei=PPLGVs2VDa707gTmrImYCg\#q=technical+guidance+wm3+waste+classification 


\subsection{Use of $\mathrm{pH}$ as an HP4/HP8 indicator}

\subsubsection{Assessment method in CLP}

According to the chemical legislation (CLP): A liquid waste is irritant or corrosive if the $\mathrm{pH}$ exceeds the range of 2 to 11.5. A method mentioned by ECHA for waste materials relates to the use of $\mathrm{pH}$ including the acid/alkali reserve. The interpretation of alkali-reserve for determination of Irritant/Corrosive properties of a test material is described in Box 2. Specific features of waste testing and the aspects to use $\mathrm{pH}$ as a parameter for hazardous waste classification is further discussed further in section 4.2.2.

\section{Box 2. Use of pH, including the acid/alkali-reserve}

Principle for interpretation of $\mathrm{pH}$ :

If the $\mathrm{pH}$ of a waste exceeds the range from 2 to 11.5, the waste is corrosive on the basis of $\mathrm{pH}$ (note! Waste with $\mathrm{pH}$ in the range from 2 to 11.5 may still be irritant or corrosive if the presence of other irritant or corrosive substances than acid or bases are suspected for example, organic hydroperoxides).

Reference for test method:

Young, J.R. How, M.J., Walker, A.P and Worth, W.H.M, 1988. “Classification as corrosive or irritant to skin of preparations containing acidic or alkaline substances, without testing animals. Toxic In Vitro 2(1): 19-26.

Principle of the acid/ alkali method:

The acid/alkali reserve gives information about the capability of a waste to maintain its $\mathrm{pH}$ and is evaluated together with $\mathrm{pH}$ of the waste.

$90 \mathrm{~g}$ of water is added to a test sample of $10 \mathrm{~g}$, and mixed with a magnetic stirrer. The acid or alkali reserve is determined by titration from the initial $\mathrm{pH}$ of the solution to $\mathrm{pH}$ 7. The amount of acid (sulphuric acid) or base (sodium hydroxide) added to adjust a water solution of waste to the target $\mathrm{pH}$ of 4 respective 10 is recorded from the titration and then expressed as sodium hydroxide (equivalent) per $100 \mathrm{~g}$ of waste (named "acid/alkali reserve") using a simple calculation formula. The waste is considered as irritant (HP4) if:

- $\quad-\mathrm{pH}+1 / 6$ alkali reserve is equal or higher than 13 .

- $\quad-\mathrm{pH}-1 / 6$ acid reserve is equal or less than 1 .

Corrosive (HP8) if:

- $\quad-\mathrm{pH}+1 / 12$ alkali reserve is equal or higher than 14.5 .

- $\quad-\mathrm{pH}-1 / 12$ acid reserve is equal or less than -0.5 . 


\subsubsection{Measurement of $\mathrm{pH}$ from waste containing a water phase}

If the waste contains a water phase, the $\mathrm{pH}$ can easily be measured and evaluated. An example of an applicable test method is ISO 10523:2008. This standard specifies a method for the determination of the $\mathrm{pH}$ value in water within the range $\mathrm{pH} 2$ to $\mathrm{pH} 12$.

The $\mathrm{pH}$ of the liquid phase of a waste is a generic waste property.

\subsubsection{Measurement of acid/alkali reserve of solid waste}

The test method referred to in the CLP is not standardised and is only presented in an article published in 1988. The European standardisation organization CEN/TC 292 "Characterization of waste" has developed several test methods for determination of the acid and or base neutralisation capacity (the so-called buffer capacity) of waste materials. The buffer capacity can easily be re-calculated to an equivalent acid/alkali reserve.

The following methods can be used for determination of acid/alkalireserve of a solid waste:

- The CLP method referring to following reference: Young, J.R. How, M.J., Walker, A.P and Worth, W.H.M, 1988. "Classification as corrosive or irritant to skin of preparations containing acidic or alkaline substances, without testing animals. Toxic In Vitro 2(1): 19-26.

- EN 15364 "Characterization of waste - Leaching behaviour tests Acid and base neutralization capacity test".

- EN 14429 "Characterization of waste. Leaching behaviour tests. Influence of $\mathrm{pH}$ on leaching with initial acid/base addition".

- EN 14997 "Characterization of waste - Leaching behaviour tests Influence of $\mathrm{pH}$ on leaching with continuous $\mathrm{pH}$-control".

The performance of the CLP test is not well described, leaving for example open protocols such as sample pre-treatment (crushing, drying, pre-equilibrium time prior to acid/base addition, contact time during test performance, quality of leachant etc.). All the CEN test methods above provide information on the buffer capacity of the waste, but in this context the $\mathrm{pH}$ dependence test with continuous $\mathrm{pH}$ control is most practical. The test method requires an automatic titrator but saves labour costs. The performance conditions of the CLP test and the pH dependence test are compared in Table 8 
Table 8: Comparison of the test method mentioned in CLP with the standardised pH dependence with continuous $\mathrm{pH}$ control

\begin{tabular}{|c|c|c|}
\hline Test & pH-dependence test EN 14997 & CLP test \\
\hline Scope & $\begin{array}{l}\text { A measure for the overall buffering ca- } \\
\text { pacity of a waste against the change in } \\
\mathrm{pH} \text { at specific } \mathrm{pH} \text { values. Influence of } \\
\mathrm{pH} \text { on the leachability of inorganic con- } \\
\text { stituents from waste materials at spe- } \\
\text { cific } \mathrm{pH} \text { values }\end{array}$ & $\begin{array}{l}\text { Assessment of irritation and corrosion potential } \\
\text { of substances with a combination of } \mathrm{pH} \text { and buff- } \\
\text { ering capacity }\end{array}$ \\
\hline Developed for (materials) & All waste materials & Product classification as corrosive or irritant \\
\hline Principle & $\begin{array}{l}\text { Sample is mixed with distilled water } \\
\text { and } \mathrm{pH} \text { level of the solution is kept at a } \\
\text { predetermined } \mathrm{pH} \text { value (in this case } \\
\mathrm{pH} 4 \text { or } 10 \text { ) by using an automated } \mathrm{pH} \\
\text { titrator }\end{array}$ & $\begin{array}{l}\text { Sample is mixed with water and acid or base } \\
\text { added till the solution reaches } \mathrm{pH} \text { 7. The initial } \\
\mathrm{pH} \text { is recorded. Record the amount of base or } \\
\text { acid added to reach } \mathrm{pH} 4 \text { respective } \mathrm{pH} 10\end{array}$ \\
\hline Sample amount & 15,30 or $60 \mathrm{~g}$ calculated on dry matter & $10 \mathrm{~g}$ (no specification on dry content of sample) \\
\hline Sample grain size & $<1 \mathrm{~mm}$ & Not specified \\
\hline Test vessel & $\begin{array}{l}\text { Vessel with lid with small openings for } \\
\text { electrodes, input for acid/base and } \\
\text { output of gas to prevent reactions with } \\
\mathrm{CO}_{2} \text {, at high pH it is recommended to } \\
\text { perform the test under } \mathrm{N}_{2}\end{array}$ & Not specified \\
\hline Chemicals & Nitric acid or sodium hydroxide & Sulphuric acid or sodium hydroxide \\
\hline $\mathrm{L} / \mathrm{S}$ & Target 10 & At start 10 \\
\hline Test duration & $48 \mathrm{~h}$ & Not specified \\
\hline Mixing & Stirring (horizontal) & Manually or mechanically \\
\hline $\begin{array}{l}\text { Requirement on achieve- } \\
\text { ment of equilibrium con- } \\
\text { dition in test }\end{array}$ & Yes & No \\
\hline Test limitations & $\begin{array}{l}\text { Time-dependent leaching of sub- } \\
\text { stances (slowly leachable) not ad- } \\
\text { dressed } \\
\text { Matrix interference }\end{array}$ & Matrix interference \\
\hline Expression of results & $\begin{array}{l}\text { Acid/base added for each target } \mathrm{pH} \\
\text { (mol } \mathrm{OH}^{-} \text {or } \mathrm{H}^{+} / \mathrm{kg} \text { sample) }\end{array}$ & $\begin{array}{l}\mathrm{g} \text { of } \mathrm{NaOH} \text { (equivalent)/100 } \mathrm{g} \text { of } \\
\text { substance }\end{array}$ \\
\hline $\begin{array}{l}\text { Criteria for test } \\
\text { interpretation }\end{array}$ & CLP criteria also applicable for this test & Yes \\
\hline
\end{tabular}




\subsection{Experience and applicability of the alkali reserve method}

In a Finnish study the titration method referred in the ECHA document and the standardised CEN pH dependence test method EN 14997 for determination of the acid/alkali reserve were compared. ${ }^{41}$ Six ash samples and one sample from crushed demolition waste were tested. In Table 9 some results of the tests are compared. For some ash samples the free $\mathrm{CaO}$ was determined with the standard EN 451-1. Further information on the study is presented in Appendix 1. The conclusions of the study are:

- The test performance conditions of the CLP-test are not specified and results will most likely vary dependent on the used test conditions. For example, the initial $\mathrm{pH}$ value, which is crucial in calculation of results, is influenced by contact time. The buffer capacity (or alkali reserve) is higher in the $\mathrm{pH}$ dependence test because of longer contact time.

- The titration method ("CLP-method") referred to in the ECHA document yielded similar results as did the CEN pH-dependence test EN 14997, but a standardised method is more reliable (especially in legal issues).

- The titration method ("CLP-method") needs a more detailed protocol if it is to be used for regulatory purposes (why not use an existing and fully applicable CEN method instead?). There is already a significant amount of experience with the applicability of CEN methods to waste materials.

${ }^{41}$ Finnish FINHAZ-study (2014-15): “Waste classification of ashes from energy production, waste incineration and construction demolition waste - testing and assessment of critical hazardous properties". 
Table 9: Comparison of the acid/alkali-method and the standardised $\mathrm{pH}$ dependence method. Note! Samples pretreated similarly for both methods

\begin{tabular}{|c|c|c|c|c|c|c|}
\hline \multirow[t]{2}{*}{ Waste type } & \multirow{2}{*}{$\begin{array}{r}\mathrm{CaO} \text { content as \% } \\
\text { (according to stan- } \\
\text { dard EN451-1) }\end{array}$} & \multicolumn{2}{|c|}{$\begin{array}{l}\text { Alkali reserve method } \\
\text { (CLP) }\end{array}$} & \multicolumn{2}{|c|}{$\begin{array}{l}\text { pH dependence test } \\
\text { EN } 14997\end{array}$} & \multirow[t]{2}{*}{$\begin{array}{r}\text { Remarks/ } \\
\text { Interpretation }\end{array}$} \\
\hline & & Initial pH & $\begin{array}{r}\mathrm{NaOH} / 100 \\
\text { g sample }\end{array}$ & $\begin{array}{r}\text { Initial } \\
\text { pH }\end{array}$ & $\begin{array}{r}\mathrm{g} \mathrm{NaOH} / 100 \mathrm{~g} \\
\text { sample }\end{array}$ & \\
\hline $\begin{array}{l}\text { Fly ash from SRF in- } \\
\text { cineration }\end{array}$ & - & 10.2 & 0.04 & 10.3 & 0.08 & $\begin{array}{l}\text { Not irritant. } \\
\text { not corrosive }\end{array}$ \\
\hline $\begin{array}{l}\text { Fly ash from coal fi- } \\
\text { ring }\end{array}$ & - & 11.9 & 0.68 & 11.6 & 0.93 & $\begin{array}{l}\text { Not irritant. } \\
\text { not corrosive }\end{array}$ \\
\hline $\begin{array}{l}\text { Fly ash from } \\
\text { co-incineration of } \\
\text { SRF, peat and } \\
\text { wood biomass }\end{array}$ & 3.2 & 12.7 & 5.6 & 12.2 & 5.6 & $\begin{array}{r}\text { Irritant, } \\
\text { not corrosive }\end{array}$ \\
\hline $\begin{array}{l}\text { Fly ash from co-in- } \\
\text { cineration of SRF } \\
\text { and recycled wood }\end{array}$ & 3.9 & 10.5 & 1.2 & 10.5 & 1.3 & $\begin{array}{r}\text { Not irritant, } \\
\text { not corrosive }\end{array}$ \\
\hline $\begin{array}{l}\text { Fly ash from } \\
\text { co-incineration of } \\
\text { peat, wood bio- } \\
\text { mass and sludge }\end{array}$ & 1,2 & 12,7 & 3.0 & 12.8 & 3.6 & $\begin{array}{r}\text { Irritant, } \\
\text { not corrosive }\end{array}$ \\
\hline $\begin{array}{l}\text { Fly ash from } \\
\text { co-incineration of } \\
\text { SRF, wood biomass } \\
\text { and sludge }\end{array}$ & - & 12.6 & 7.6 & 11.8 & 8.2 & $\begin{array}{r}\text { Irritant, } \\
\text { not corrosive }\end{array}$ \\
\hline Crushed concrete & - & 11.9 & 1.9 & 11.7 & 2.8 & $\begin{array}{l}\text { Not irritant, } \\
\text { not corrosive }\end{array}$ \\
\hline
\end{tabular}

Other observations about the tests:

- Combinations of $\mathrm{pH}$ and alkali reserve measures in many cases the same property of a material than concentrations of oxides and hydroxides of alkali and alkali earth metals (the standardized methods (EN 451-1, EN 196-2, SFS 5188) for certain alkali /alkali earth metals are also based on titration using different types of extraction methods).

- Measurements of $\mathrm{CaO}$ were not useful in this context because also $\mathrm{Ca}(\mathrm{OH})_{2}, \mathrm{~K}_{2} \mathrm{O} / \mathrm{KOH}, \mathrm{Na} 2 \mathrm{O} / \mathrm{NaOH}$ need to be taken into account in the assessment of HP4/HP8. 
- According to the $\mathrm{pH}$ and alkali reserve approach, high-pH and highbuffering ashes could be regarded as irritant.

- The methodology is easy and straightforward to perform.

\subsection{Use of in vitro test methods}

Not only compounds generating a low/high pH may cause hazards related to irritancy or corrosivity. For example zinc chloride at concentrations above $5 \%$ may render the waste hazardous based on composition data. Therefore the UK guideline suggests use of an in vitro test compliment to acid/alkali-reserve.

The in vitro test methods for chemical testing described in ECHA are based on the use of artificial membranes. The test sample should generally be a fine powder or a liquid. In testing solid waste, a test portion of $20-25 \mathrm{mg}$ is applied on the membrane. The test is not very practical for waste materials since they are often rather heterogeneous.

The French guidance report includes the following examples of potentially critical substances with a concentration limit of $1 \%$ for HP4: chromium (VI) (e.g. as chromyl dichloride; ${ }^{42}$ chromic oxychloride), aluminium (as aluminium lithium hydride) and boron (as boron tribromide trioxide), nickel (as nickel(II)octanoat), phosphorous (as phosphoryl trichloride) and sulphur (as thionyl dichloride; thionyl chloride). Fly ashes from wood incineration, municipal solid waste incinerator (MSWI) bottom ash, concrete waste and sludges from waste water treatment do not generally contain significant amounts of aluminium, chromium, boron, and nickel (see Appendices 1-3). It is also unlikely that sulphur and phosphorous can occur in significant concentrations in a critical form due to the origin of these wastes. The authors do not see the in vitro test as necessary for these waste streams.

${ }^{42}$ Hennebert P, Rebischung F. 2013. Waste Hazardousness Assessment - Proposition of methods. Report INERISDRC-13-136159-04172A- 69 pp. http://www.ineris.fr/centredoc/drc-13-136159-04172ahazardouswaste-assessment-f3-1379929842.pdf 


\subsection{Recommendations for testing of $\mathrm{CaO}$ and/or $\mathrm{Ca}(\mathrm{OH})_{2}$ wastes}

The authors recommend the use of the CEN methods (especially pH dependence test with continuous pH-control) for the assessment of HP4 /HP8 of ashes and slags.

Typical waste materials like ashes, sludge and slags do not generally contain compounds at such concentrations that would render them hazardous in relation to HP4/HP8 based on other compounds than alkaline compounds (generating high $\mathrm{pH}$ ). Therefore the authors do not see the in vitro test as necessary for these waste streams. 


\section{Use of calculation methods and test methods for determination of hazardous property "ecotoxicity" (HP 14)}

Environmental hazardous properties and notably "ecotoxicity" (HP 14) remains an area of ambiguity for the classification of waste. During the revision of Annex III to the WFD consensus was reached on the relation between the assessment of hazardous properties of waste (HP) and the corresponding criteria (hazard statements) and calculations for mixtures under the CLP for all other hazardous properties. Pending the establishment of new criteria for HP14, the older legislation still applies. ${ }^{43}$

Ideally, the starting point of the HP14 assessment should be to harmonise the criteria and methodologies with the CLP and its application to mixtures. It allows the classification of waste to be based on the large amount of information generated under the CLP and REACH which is the largest database on chemicals in history. Harmonised assessment criteria also facilitate the application of the bridging principle or other regulations such as Seveso III Directive and ADR which share the same criteria on waste management and transport. 44

For wastes with mirror entries, the hazardous property HP 14 is particularly challenging and a critical property for many recyclable waste streams. Therefore, prior to the final decisions about HP 14 (ecotoxicity), it is crucial that also the consequences on waste management and waste recycling and conflicts with EU targets in circular economy are carefully evaluated.

\footnotetext{
${ }^{43}$ According to a note in the revised Annex III the attribution of the hazardous property HP 14 is still to be made on the basis of the criteria laid down in the Annex VI to the repealed Council Directive 67/548/EEC. ${ }^{44}$ European agreement concerning the international carriage of dangerous goods by road (ADR) - latest updated in 2015.
} 


\subsection{Assessment of ozone depleting properties according to the CLP}

Substances with ozone depleting properties are deemed environmentally hazardous in both the DSD (R59) and the CLP (H 420). There are no test methods to assess ozone depleting properties, but reference is made to Annex I in Regulation (EC) No 1005/2009 of the European Parliament and of the Council of 16 September 2009 on substances that deplete the ozone layer. For mixtures, no summation of all classified substances is required and the limit for hazard classification is $0.1 \%$ content for individual classified substances in the waste.

For Sweden it has been estimated that circa 2,000 tons of isolation materials contaminated with ozone depleting substances at concentrations that trigger classification as hazardous waste are present in constructions. ${ }^{45}$

\subsection{Hazard classification of ecotoxic properties according to the CLP}

\subsubsection{Hazard classification based on toxicity testing}

Hazard classification categories are linked to the toxicity of a substance or a mixture in an aquatic biotest. Hazardous to the aquatic environment is differentiated into short-term acute aquatic hazard and long-term aquatic hazard. Chronic toxicity is classified into three different categories based on the degree of toxicity, see Table 10. Classification is based on three basic characteristics: toxicity, degradability and bioaccumulation. For mixtures, it is not possible to assess biodegradability and bioaccumulation by testing. Since wastes generally are multi-constituent and complex mixtures, classification of waste has to rely solely on toxicity criteria. This reduces the complexity of assessment of test results (CLP Table 4.1.0) significantly, see Table 10. Toxicity data for a test battery of three different trophic levels (fish, crustacean, algae/aquatic plants) are needed to assign a classification. The most sensitive (lowest) of the available toxicity values is used for classification. The criteria for assessment and clas-

45 http://www.naturvardsverket.se/Nyheter-och-pressmeddelanden/Nyhetsbrev/Tillsynsnytt/Artiklar2012/Nu-kan-du-se-seminarierna-i-bygg-och-rivningskampanjen-pa-webben/ 
sification of ecotoxic properties are only based on aquatic biotests. Consequently, terrestrial biotests or other types of non-aquatic biotests cannot be used as a basis for the assessment according to the CLP.

\begin{tabular}{|c|c|c|c|}
\hline $\begin{array}{l}\text { Hazard Class and } \\
\text { Category Code }\end{array}$ & $\begin{array}{l}\text { Hazard statement } \\
\text { code }\end{array}$ & $\begin{array}{l}\text { Criteria aquatic } \\
\text { Chronic bioassays }\end{array}$ & $\begin{array}{l}\text { Criteria aquatic } \\
\text { Acute bioassays }\end{array}$ \\
\hline Short-term aquatic hazard & & EC50 & EC50 \\
\hline Acute Category 1 & $\mathrm{H} 400$ & - & $<1 \mathrm{mg} / \mathrm{l}$ \\
\hline Long-term aquatic hazard & & NOEC or $\mathrm{EC}_{\mathrm{x}}$ & $\mathrm{EC}_{50}$ \\
\hline Chronic Category 1 & $\mathrm{H} 410$ & $0.1 \mathrm{mg} / \mathrm{l}$ & $1 \mathrm{mg} / \mathrm{l}$ \\
\hline Chronic Category 2 & H411 & $1 \mathrm{mg} / \mathrm{l}$ & $10 \mathrm{mg} / \mathrm{l}$ \\
\hline Chronic Category 3 & $\mathrm{H} 412$ & - & 100 mg/l \\
\hline Chronic Category 4 & H413 & $<1 \mathrm{mg} / \mathrm{l}^{*}$ & - \\
\hline
\end{tabular}

Chronic category 4 is a "safety net" classification criteria for substances where no acute toxicity is recorded at levels up to the water solubility and which are not rapidly degradable or indicating a potential to bioaccumulate. When there are adequate chronic toxicity data available for the mixture as a whole showing ECx(s) or NOEC(s) of the tested mixture $>1 \mathrm{mg} / \mathrm{l}$ for all trophic levels a mixture or a waste will not be classified as hazardous under $\mathrm{H} 413$.

Based on Table 10 it is clear that an assessment factor of 10 is applied if short term acute biotests are used for assessment of chronic toxicity and that chronic biotests are regarded to be more sensitive than acute biotests.

While the CLP and REACH share some test methods, some test methods have been specially developed under the CLP. The CLP guidance ${ }^{46}$ refers to specific methods that can support the hazard assessment of mixtures e.g. the OECD guidance document no 23 on testing of difficult substances and mixture ${ }^{47}$ and the transformation and dissolution (T/D) protocol (see further 5.3). ${ }^{48}$ These two guidance documents can be used to create a leachate from complex mixtures to be tested in biotests. The T/D protocol is a key document in relation to the classification of metals and

\footnotetext{
${ }^{46}$ ECHA 2013 CLP Guidance document. Guidance on the Application of the CLP Criteria. Version 4.0 - November 2013.

47 OECD 2002. Guidance Document on Aquatic Toxicity Testing of Difficult Substances and Mixtures, OECD Series on Testng and Assessment, No. 23, OECD Publishing.

48 OECD 2001. OECD series on testing and assessment, number 29. ANNEX 10. Guidance on transformation/dissolution of metals and metal compounds in aqueous media, OECD Series on Testing and Assessment No. 29. OECD Publishing.
} 
metal compounds and gives precise requirements on the leachant, the relevant $\mathrm{pH}$ range and time for leaching. It is well established and validated for metal compounds but guidance on application on complex metal-containing materials is still limited. ${ }^{49}$ The T/D protocol offers additional advantages since test results can be evaluated by comparing the leached concentrations to relevant ecotoxicological reference values (ERVs) e.g. EC50 or NOEC for the free and dissolved metal ion. That eliminates the need of performing biotests and enables comparisons of testing results to the full available data set on ecotoxicology instead of a limited (incomplete) biotest battery. This is especially favourable in the light of the cost and ethical restrictions related to the performance of tests on vertebrates (fish). The main requirements on $\mathrm{T} / \mathrm{D}$ protocol generation approach are:

- Leaching is performed at $\mathrm{L} / \mathrm{S}$ ratios of $10,000 \mathrm{l} / \mathrm{kg}(100 \mathrm{mg} / \mathrm{l})$, $100,000 \mathrm{l} / \mathrm{kg}$ and $1,000,000 \mathrm{l} / \mathrm{kg}(1 \mathrm{mg} / \mathrm{l})$ in order to correspond to the criteria in table 10 .

- The particle size of a solid material during leaching should be $<1 \mathrm{~mm}$.

- Batch leaching is performed for at least 48 hours. Extended leaching at 7 or 28 days is used to support assessment of transformation rates.

- The $\mathrm{pH}$ of the test is controlled to generate leachates within a $\mathrm{pH}$ range of 5.5-8.5.

- Insoluble fractions are removed by membrane filtration.

- At least three replicates are performed.

- The dissolved concentrations are compared to the relevant ERVs.

\subsubsection{Hazard classification based summation formula}

In order to minimise the need for (unnecessary) testing, mixtures can be assessed based on the presence of hazardous substances. This assessment is based on the sum of the contents of hazardous substances with an ecotoxic property. The CLP also operates with cut-off values for assessment of ecotoxic properties. If a substance is present in the waste below its cut-off value it shall not be included in the summation for classification.

${ }^{49}$ ECHA 2015 CLP Guidance document. Guidance on the Application of the CLP Criteria. Version 4.1, June 2015. Annex IV. IV.5.6.1 Classification of alloys and complex metal containing materials. 
The summation approach is supported by scientific consensus on the application the principle of concentration addition as a proxy for assessment of the toxic effects of a chemical mixture..$^{50}$ The application of the principle of concentration addition will in most cases lead to a conservative estimation of the toxicity generated in a toxicity test. ${ }^{51}$ In the CLP the use of the additivity principle for an ingredient-based classification procedure can proceed via two routes:

- A specific additivity formula taking toxicity via $\mathrm{LC}_{50} / \mathrm{EC}_{50}$ and NOEC into account (sliding system).

- A staggered summation using a weighting system based on classifycation (hazard statement codes), cut-off values and concentration limits.

The staggered summation approach was applied already in the repealed Dangerous Preparations Directive (DPD) and is the preferred route in the CLP,52 and the approach that has been suggested for implementation in Annex III to the WFD. Summation is performed separately for acute and chronic hazards in order to correspond to the categories used to classify mixtures based on testing, see Table 10. As a consequence of technical and scientific progress, the CLP introduces the use of $M$ factors for highly environmentally toxic substances. The concept of $M$ factors has been established to add an increased weight to very toxic substances when classifying mixtures. $M$ factors are only applicable when substances are classified hazardous to the aquatic environment, Aquatic Acute 1 (labelled with code H400) and Aquatic Chronic 1 (code 410)). The $M$ factors are substance-specific, and the presence in a mixture of substances having an $\mathrm{M}$ factor will strongly influence the classification of the mixture.

The CLP stipulates that a mixture is classified as hazardous under the associated hazard statement code if the weighted sum of hazardous substances exceeds a fraction of $25 \%$ of the total mixture.

A mixture shall be classified hazardous, based on a weighted summation of the associated Aquatic Acute substances according to equation (1)

$H 400=\sum_{i} C_{i}^{H 400} * M_{i}$

\footnotetext{
${ }^{50}$ Scientific Committee on Health and Environmental Risks, Scientific Committee on Emerging and Newly Identified Health Risks, Scientific Committee on Consumer Safety; Toxicity and Assessment of Chemical Mixtures; European Commission 2012.

${ }^{51}$ Hazard and Risk Assessment of Chemical Mixtures under REACH - State of the Art, Gaps and Options for Improvement, Swedish Chemicals Agency PM 3/10.

52 The Dangerous Product Directive (DPD) 1999/45/EC has been replace by CLP.
} 
A mixture shall be classified hazardous with the associated hazard code, and summation formulas for Aquatic Chronic classified substances, see eq. (2), (3) and (4)

$$
\begin{aligned}
& H 410=\sum_{i} C_{i}^{H 410} * M_{i} \\
& H 411=\sum_{i}\left(C_{i}^{H 410} * 10 * M_{i}+C_{i}^{H 411}\right) \\
& H 412=\sum_{i}\left(C_{i}^{H 410} * 100 * M_{i}+C_{i}^{H 411} * 10+C_{i}^{H 412}\right)
\end{aligned}
$$

where $\mathrm{C}_{\mathrm{i}}$ is the concentration of each classified component, $\mathrm{i}$, in $\%$.

$\mathrm{M}$ factors are applied separately for substances associated with H410 in weighting steps of 10 depending on the toxicity of the substances ( 1 or 10 or 100 , etc.) in a stepwise approach similar to the staggered summation for $\mathrm{H} 412$ where weighing factors of 10 and 100 are given to substances associated with $\mathrm{H} 411$ and $\mathrm{H} 410$.

Cut-off values are applied for both acute and chronic toxicity assessments.

If $C_{i}^{H 410} / M_{i}<0,1 \%$ or $C_{i}^{H 400} / M_{i}<0,1 \%$ then it should be excluded from the summation, and if $C_{i}^{H 411}$ or $C_{i}^{H 412}<1 \%$ than they should be excluded from the summation.

\subsection{Use of calculation methods in the assessment of HP 14}

\subsubsection{Proposed calculation formulas and $M$ factors}

The EU Commission has asked a consultant to assess the applicability of four different calculation methods (see Table 11) for classification of waste under HP14 as part of a more comprehensive study of HP14-related issues. ${ }^{53}$ According to the calculation methods proposed, the toxicity is considered separately for substances having aquatic acute and aquatic chronic properties, respectively, in Method 1 and Method 2. The waste is classified as hazardous if the limit for either acute or chronic toxicity is exceeded. In the calculation of the hazard it is assumed that the toxicity of substances is additive and that summation formulas similar to those applied in the CLP can be used for Method 1 (excluding M-factors) and Method 2. Methods 3 and 4 only apply summations separately for each

${ }^{33}$ Study to assess the impacts of different classification approaches for hazard property H 14 on selected waste streams (Bio Deloitte \& Ineris, France), final report October 2015. http://ec.europa.eu/environment/ waste/studies/pdf/H14.pdf 
hazard category (hazard code) and does not comply with the summation formulas or the principle of concentration addition applied in the chemical legislation. Neither Method 3 nor Method 4 includes assessment of Aquatic Acute toxicity.

There is no rational provided to explain why these summation methods have been chosen. Method 1 is similar to older versions of a calculation method in the now repealed Dangerous Preparations Directive (DPD) but without the use of cut-offs that where applied under DPD. ${ }^{54}$ Method 2 is equivalent to calculation methods provided under the CLP (equation 2). Based on the HP 14 consultant study it seems that Method 1 and 2 (or similar) are applied in official or unofficial guidelines by a number of Member States at present (e.g. in some of the Nordic countries). Methods 3 and 4 are not currently applied in official guidelines in any of the Member States studied in the HP 14 consultant study.

In the evaluation of the proposed methods various aspects should be stressed. On the one side the links to the CLP developed for chemicals are important and on the other hand waste-specific considerations have to be included. Both aspects are addressed below.

\begin{tabular}{|c|c|c|c|}
\hline Method 1 & Method 2 & Method 3 & Method 4 \\
\hline $\begin{array}{c}\text { IF: } \\
\mathrm{c}(\mathrm{H} 420) \geq 0.1 \%\end{array}$ & $\begin{array}{c}\text { IF: } \\
c(H 420) \geq 0.1 \%\end{array}$ & $\begin{array}{c}\text { IF: } \\
\Sigma(\mathrm{c} \mathrm{H} 420) \geq 0.1 \%\end{array}$ & $\begin{array}{c}\mathrm{IF} \\
c(\mathrm{H} 420) \geq 0.1 \%\end{array}$ \\
\hline $\begin{array}{c}\text { OR } \\
\Sigma c(H 400) \geq 25 \%\end{array}$ & $\begin{array}{c}\text { OR } \\
\text { If } \mathrm{c}(\mathrm{H} 400) \geq 0.1 / \mathrm{M} \% \text { and } \\
\Sigma(\mathrm{c} \mathrm{H} 400 \times \mathrm{M}) \geq 25 \%\end{array}$ & $\begin{array}{c}\text { OR } \\
\Sigma(\mathrm{c} \mathrm{H} 410) \geq 0.1 \%\end{array}$ & $\begin{array}{c}\mathrm{OR} \\
\Sigma(\mathrm{c} \mathrm{H} 410) \geq 2.5 / \mathrm{M} \%\end{array}$ \\
\hline $\begin{array}{c}\text { OR } \\
(100 \times \Sigma \mathrm{c} H 410)+ \\
(10 \times \Sigma \mathrm{cH} 411)+(\Sigma \mathrm{cH} 412) \\
\geq 25 \%\end{array}$ & $\begin{array}{c}\text { OR } \\
\text { If } \mathrm{c}(\mathrm{H} 410) \geq 0.1 / \mathrm{M} \% \\
\text { and } \mathrm{c}(\mathrm{H} 411)>1 \% \text { and } \Sigma \\
(\mathrm{M} \times 10 \times \mathrm{c} H 410)+\Sigma \mathrm{c} \mathrm{H} 411 \\
\geq 25 \%\end{array}$ & $\begin{array}{c}\text { OR } \\
\Sigma(\mathrm{c} \mathrm{H} 411) \geq 2.5 \%\end{array}$ & $\begin{array}{c}\text { OR } \\
\Sigma(\mathrm{c} \mathrm{H} 411) \geq 25 \%\end{array}$ \\
\hline $\begin{array}{c}\text { OR } \\
\Sigma \mathrm{c} \mathrm{H} 410+\Sigma \mathrm{cH} 411+\Sigma \mathrm{c} \\
\mathrm{H} 412+\Sigma \mathrm{c} \mathrm{H} 413 \geq 25 \%\end{array}$ & & $\begin{array}{c}\text { OR } \\
\Sigma(\mathrm{c} \mathrm{H} 412) \geq 25 \% \\
\text { OR } \\
\Sigma(\mathrm{c} \mathrm{H} 413) \geq 25 \%\end{array}$ & \\
\hline$\rightarrow$ Waste hazardous & $\rightarrow$ Waste hazardous & $\rightarrow$ Waste hazardous & $\rightarrow$ Waste hazardous \\
\hline
\end{tabular}

\footnotetext{
${ }^{54}$ Increased weight to highly toxic substances in a concept similar to M-factors was introduced under DPD in an amendment 2006 (COMMISSION DIRECTIVE 2006/8/EC of 23 January 2006 amending, Directive 1999/45/EC).
} 


\subsubsection{Critical aspects in summation methods}

\section{Identification and classification of hazardous substances}

The application of the summation methods on specific wastes requires that all toxic species can be identified, quantified and classified. Conventional chemical analysis does normally not determine all the specific compounds within a waste. It rather determines the elemental composition and the content of some specifically chosen organic substances. In order to identify, quantify and classify all relevant toxic species, a conservative generic assessment based on a realistic worst case approach is often performed (see section 2). Such an approach will overestimate the hazardousness of the waste and trigger the handling of unwarranted amounts of falsely classified hazardous wastes which is most critical for HP14 due to the low concentration limits to be applied.

Methods 2 and 4 also include multiplying factors (M factors) applied in the CLP for highly toxic substances. This means consequently that the presence of a substance having an $\mathrm{M}$ factor $>1$ will strongly influence the classification of a waste.

Annex VI to the CLP contains harmonised classifications of a large set of substances and is an important source of information for waste classification. $M$ factors have currently been defined only for a very limited number of substances in Annex VI of the CLP. In the future, harmonised M factors will most likely be developed for several additional substances. Assessment of $\mathrm{M}$ factors is mandatory for substances that are registered under REACH and the CLP and additional information on M factors are therefore available at the ECHA homepage. A hazard classification based on the harmonised list in Annex VI without assigning correct $M$ factors could underestimate the amount of waste that has hazardous properties.

Many substances that are present in waste have not been subject to registration or classification under REACH or the CLP and data for these substances will be lacking both regarding their hazard statements codes and potential $\mathrm{M}$ factors. It is currently unclear whether waste generators will be required to provide data regarding this issue. Many national guideline documents for generic assessment of specific waste streams apply conservative generic reference substances based on the list of harmonised classifications. If the concept of conservative generic substances is kept while more stringent criteria are introduced (e.g. by applying $\mathrm{M}$ factors) the amount of waste that will be classified as hazardous could increase substantially. Hence guidance will be needed on both the speciation of substances in the waste and the classification of substances for which information on the classification is absent. 
Guidance is also needed on whether and how classification data of substances can be extracted from the ECHA C\&L inventory or the REACH registration files. The classification data may differ substantially from one registration to another and it is not obvious which one to choose. This may lead to different classifications of waste dependent on the source of information. The speciation and classification assessment is the most important source of uncertainty in the assessment with a huge impact on the outcome for all methods. Even in the case where the speciation of the substances in the waste is improved by applying the best available techniques, the classification assessment is the most important source of uncertainty spanning over several orders of magnitude. This is the case even if $\mathrm{M}$ factors are not applied, but the uncertainty increases with the application of $\mathrm{M}$ factors. The CLP summation method for mixtures can also give misleading results for waste due to the fact that sorption of dissolved toxic species on organic and inorganic sorbents can reduce their bioavailability. 55

\section{Comparison of the summation methods}

Characteristics of the summation methods and compliance with the CLP and other legislation for hazardous chemicals are assessed in Table 12. One aspect is to evaluate how the different summation methods fulfil the purpose of the revised legislation i.e. "to adapt the hazardous waste classification system to technical and scientific progress and to bring the system in alignment with the new chemicals legislation." But there are also other considerations like the ease of use of the method, e.g. retrieving relevant hazard classifications of identified substances in the waste or the use of safety data sheets as basis for classification. ${ }^{56}$

${ }^{55}$ Stiernström, Wik 0, Bendz D. Critical evaluation of methods for hazard classification of waste ecotoxic properties, Sardinia Conference 2015.

${ }^{56}$ BiPRO Guidance document On the definition and classification of hazardous waste DRAFT VERSION from 08 June 2015, http://ec.europa.eu/environment/waste/pdf/consult/Draft\%20guidance\%20document 09062015.pdf 
Table 12: Comparison of the different summation methods (partly subjective)

\begin{tabular}{|c|c|c|c|c|}
\hline Characteristics & Method 1 & Method 2 & Method 3 & Method 4 \\
\hline $\begin{array}{l}\text { Alignment with the CLP and other relevant legislation in } \\
\text { which the hazard classification of waste is of } \\
\text { importance }{ }^{57}\end{array}$ & Partly & Yes & No & No \\
\hline $\begin{array}{l}\text { Compliance with the principle of concentration } \\
\text { addition }^{58}\end{array}$ & Partly & Yes & No & No \\
\hline Simplified summation formulas compared to the CLP & Partly & No & Partly & Partly \\
\hline Application of read-across or bridging principles possible & Partly & Yes & No & No \\
\hline $\begin{array}{l}\text { Data on classification easily accessible from CLP Annex VI, } \\
\text { or the C\&L Inventory }\end{array}$ & Yes & Partly & Yes & Partly \\
\hline Inclusion of acute toxicity in calculation formulas & Yes & Yes & No & No \\
\hline Inclusion of chronic toxicity in calculation formulas & Yes & Yes & Yes & Yes \\
\hline Use of $\mathrm{M}$ factors & No & Yes & No & Yes \\
\hline Use of cut-off value & No & Yes & No & No \\
\hline
\end{tabular}

The use of $\mathrm{M}$ factors influences significantly the concentration limits to be applied in the assessment. It is interesting to compare the results of applying the four different methods on substances classified hazardous by $\mathrm{H} 410$ and with different $\mathrm{M}$ factors. The result of such a comparison is shown in Table 13. Experience shows that such substances usually entirely control the hazard classification of waste. Substances with lower toxicity (H411-H413) require very high concentrations in waste (compared to substances classified hazardous by H410) in order to trigger and control hazard classification. This is normally a rare situation and their contribution to the amount of waste classified as hazardous will therefor only be limited. The results in Table 13 show that Method 3 will give the lowest critical concentration and thus the largest amount of hazardous waste for all substances with an M factor below 100. Method 2 and Method 4 give the same results.

\footnotetext{
57Seveso III -Directive (Directive 2012/18/EU) and Directive on the Transport of Dangerous Goods (2008/68/EC).

${ }^{58}$ Compliance with the principle of concentration addition ensures a reasonable expected comparability with ecotoxity testing.
} 
Table 13: Comparison of the critical concentration for classification of waste as hazardous generated by the different summation methods and for a substance classified as hazardous by $\mathrm{H} 410$

\begin{tabular}{lrrrr} 
M Factor & $\mathbf{1}$ & $\mathbf{1 0}$ & $\mathbf{1 0 0}$ & $\mathbf{1 , 0 0 0}$ \\
Method 1 & & & & \\
Method 2 & $0.25 \%$ & $0.25 \%$ & $0.25 \%$ & $0.25 \%$ \\
Method 3 & $2.5 \%$ & $0.25 \%$ & $0.025 \%$ & $0.0025 \%$ \\
Method 4 & $0.1 \%$ & $0.1 \%$ & $0.1 \%$ & $0.1 \%$ \\
& $2.5 \%$ & $0.25 \%$ & $0.025 \%$ & $0.0025 \%$ \\
\hline
\end{tabular}

If a generic $\mathrm{M}$ factor of 10 is assumed, both Method 1, Method 2 and Method 4 will give similar classifications with a concentration limit of $0.25 \%(2,500 \mathrm{mg} / \mathrm{kg})$ for ingredients classified as hazardous by H410. An $\mathrm{M}$ factor of 10 has been proposed in the HP 14 consultant study, Appendix 6 for many elements that often are critical for hazard classification (e.g. $\mathrm{Cu}, \mathrm{Pb}, \mathrm{Zn}, \mathrm{As}, \mathrm{CrVI}) .{ }^{59}$ It thus seems reasonable that Method 1 and Method 2 will give roughly the same level of environmental protection and economic and social impact. In this context it must be emphasised that there is neither any legal nor scientific support for assigning a default $M$ factor of 1 as was done in the HP14 consultant study, chapter 5.4.2 and chapter 5.5. This is clearly a weakness of the study, and it makes the comparison of the methods without taking potential future assignations of $\mathrm{M}$ factors into account questionable. Correct assignment of $\mathrm{M}$ factors is mandatory as part of self-classification under the CLP, also for substances with harmonised classification (in the event that harmonized $M$ factors are lacking). Information on M factors is thus available under CLP and REACH.

\section{An example of the use of summation methods for incinerator bottom ash}

As an example, the proposed calculation methods in Table 11 have been used to assess the ecotoxicity of the different concentration levels in bottom ashes. This example only focuses on a few heavy metals (here $\mathrm{Zn}, \mathrm{Cu}$ and $\mathrm{Pb}$ ) that are known to control HP14 assessment of bottom ashes based on the summation method. Data on the concentration levels in European bottom ashes from municipal waste incinerators have been collated in Appendix 3.

${ }^{59}$ Study to assess the impacts of different classification approaches for hazard property H 14 on selected waste streams (Bio Deloitte \& Ineris, France), final report october 2015. http://ec.europa.eu/environment/ waste/studies/pdf/H14.pdf 
As the exact speciation of the substances in waste materials like ashes is not known, the metals in waste from thermal processes are often assumed to appear exclusively as oxides (such as $\mathrm{ZnO}, \mathrm{CuO}$ and $\mathrm{PbO}$ ). In reality only certain fractions of the metals probably appear as oxides in the original ash, and several other substances have been identified..$^{60}$ All these oxides $(\mathrm{ZnO}, \mathrm{PbO}$ and $\mathrm{CuO})$ are likely to be assigned with the hazardous statement codes $\mathrm{H} 400$ and $\mathrm{H} 410$ (even if no harmonised classification exists yet for $\mathrm{CuO}$ or $\mathrm{PbO}$ ). For method 2 and 4 calculations are made for $\mathrm{M}$ factors of 1,10 and 100 (Note! The M factors of 1, 10 or 100 are hypothetical; the calculations are only made to assess the consequences of different $M$ factors). The outcome of the assessment is summarised in Table 14.

The calculations clearly show that for the bottom ash example, already a metal level of $2,000-2,300 \mathrm{mg} / \mathrm{kg}$ is critical in the waste classification for Method 1 and Method 3 and if $\mathrm{M}>10$ for $\mathrm{Cu}$ or $\mathrm{Zn}$ also for methods 2 and 4. In this example, the results for Method 2 and Method 4 are the same, because only substances with hazardous codes $\mathrm{H} 400$ and $\mathrm{H} 410$ are considered. The ranking of the methods from most severe to less severe is: Method $3>$ Method $1>$ Method 2/4. However, the ranking depends also on the magnitude of the $\mathrm{M}$ factor. Applying a generic $\mathrm{M}$-factor of 10 which has been proposed for $\mathrm{Zn}, \mathrm{Pb}$ and $\mathrm{Cu}$ would make Method 1, 2 and 4 equivalent. ${ }^{61}$

\footnotetext{
${ }^{60}$ Stiernström, Wik 0, Bendz D. Critical evaluation of methods for hazard classification of waste ecotoxic properties, Sardinia Conference 2015.

${ }^{61}$ Appendix 6, Study to assess the impacts of different classification approaches for hazard property H 14 on selected waste streams (Bio Deloitte \& Ineris, France), Final report October 2015.
} 


\begin{tabular}{|c|c|c|c|c|c|}
\hline & $\begin{array}{l}\text { Concentration le- } \\
\text { vels in ashes }\end{array}$ & Method 1 & Method 2 & Method 3 & Method 4 \\
\hline $\begin{array}{l}\text { Average com- } \\
\text { position }\end{array}$ & $\begin{array}{l}\mathrm{Cu}: 3,275 \mathrm{mg} / \mathrm{kg} \\
\mathrm{Zn:} 3,241 \mathrm{mg} / \mathrm{kg} \\
\mathrm{Pb}: 1,309 \mathrm{mg} / \mathrm{kg}\end{array}$ & Ecotoxic & $\begin{array}{l}\text { Ecotoxic if } \mathrm{M} \\
\text { factor at least } \\
10 \text { for } \mathrm{Cu} \text { or } \mathrm{Zn} \\
\text { (or } 100 \text { for } \mathrm{Pb} \text { ) }\end{array}$ & Ecotoxic & $\begin{array}{l}\text { Ecotoxic if } \mathrm{M} \\
\text { factor at least } \\
10 \text { for } \mathrm{Cu} \text { or } \mathrm{Zn} \\
\text { (or } 100 \text { for } \mathrm{Pb} \text { ) }\end{array}$ \\
\hline Median & $\begin{array}{l}\mathrm{Cu}: 2,510 \mathrm{mg} / \mathrm{kg} \\
\mathrm{Zn:} 2,871 \mathrm{mg} / \mathrm{kg} \\
\mathrm{Pb}: 1,058 \mathrm{mg} / \mathrm{kg}\end{array}$ & Ecotoxic & $\begin{array}{l}\text { Ecotoxic if } \mathrm{M} \\
\text { factor at least } \\
10 \text { for } \mathrm{Cu} \text { or } \mathrm{Zn} \\
\text { (or } 100 \text { for } \mathrm{Pb} \text { ) }\end{array}$ & Ecotoxic & $\begin{array}{l}\text { Ecotoxic if } \mathrm{M} \\
\text { factor at least } \\
10 \text { for } \mathrm{Cu} \text { or } \mathrm{Zn} \\
\text { (or } 100 \text { for } \mathrm{Pb} \text { ) }\end{array}$ \\
\hline Minimum & $\begin{array}{l}\mathrm{Cu}: 738 \mathrm{mg} / \mathrm{kg} \\
\mathrm{Zn:} 1,142 \mathrm{mg} / \mathrm{kg} \\
\mathrm{Pb}: 197 \mathrm{mg} / \mathrm{kg}\end{array}$ & Ecotoxic & $\begin{array}{l}\text { Ecotoxic only if } \\
\mathrm{M} \text { factors at } \\
\text { least } 10 \text { for } \\
\text { both } \mathrm{Cu} \text { and } \mathrm{Zn}\end{array}$ & Ecotoxic & $\begin{array}{l}\text { Ecotoxic only if } \\
\mathrm{M} \text { factors at } \\
\text { least } 10 \text { for } \\
\text { both } \mathrm{Cu} \text { and } \mathrm{Zn}\end{array}$ \\
\hline Maximum & $\begin{array}{l}\mathrm{Cu}: 17,620 \mathrm{mg} / \mathrm{kg} \\
\mathrm{Zn}: 9,370 \mathrm{mg} / \mathrm{kg} \\
\mathrm{Pb}: 6,441 \mathrm{mg} / \mathrm{kg}\end{array}$ & Ecotoxic & Ecotoxic & Ecotoxic & Ecotoxic \\
\hline
\end{tabular}

Figures 5-8 give examples of the content of $\mathrm{Zn}$ and $\mathrm{Cu}$ in Danish incinerator bottom ashes $(\mathrm{N}=1,226)$. Over $95 \%$ of the samples contain an apparent $\mathrm{ZnO}$ content triggering hazard classification at $2,000 \mathrm{mg} / \mathrm{kg} \mathrm{Zn}$ (a limit of $0.25 \%$ for $\mathrm{ZnO}$ corresponds to a limit of $0.20 \%$ for analysed elemental $\mathrm{Zn})$. For $\mathrm{Cu}$ the corresponding percentage is over $80 \%$ of the samples. In practice this means that in the future bottom ash should be subjected to further assessment (see Fig. 5-8), where ecotoxicity testing is introduced as one option.

In Figure 5 the data points show the data points show the content of $\mathrm{Cu}$ in incineration bottom ash (IBA) samples from 26 different incinerators (a total of 1,226 data points). The three horizontal lines indicate contents of $\mathrm{Cu}$ corresponding to contents of $\mathrm{CuO}$ of respectively $0.025 \%$ (green line), $0.1 \%$ (blue line) and $0.25 \%$ (red line). The average, median and 10 and 90 percentile contents are referring to contents of $\mathrm{Cu}$. Figure 6 shows more clearly how large a percentage $(80 \%)$ of the IBA samples exceeds the content of $\mathrm{Cu}(2,000$ $\mathrm{mg} / \mathrm{kg}$ ) corresponding to a content of $\mathrm{CuO}$ of $2,500 \mathrm{mg} / \mathrm{kg}$ or $0.25 \%$ (the red line). Figure 7 and 8 present similar data for the content of Zn in IBA compared to a content of $250 \mathrm{mg} / \mathrm{kg}$ (or $0.025 \%$ ) and 2,500 mg/kg (or $0.25 \%$ ) of $\mathrm{ZnO}$ corresponding to contents of 2,000 mg/ $\mathrm{kg}$ and $200 \mathrm{mg} / \mathrm{kg}$, respectively, of $\mathrm{Zn}$ in the IBA. For $\mathrm{Zn}$ it can be seen that $95 \%$ of the 1,220 samples of IBA have contents of $\mathrm{Zn}$ that exceed a value $(2,000 \mathrm{mg} / \mathrm{kg})$ corresponding to a content of $0.25 \%$ of $\mathrm{ZnO}$. 


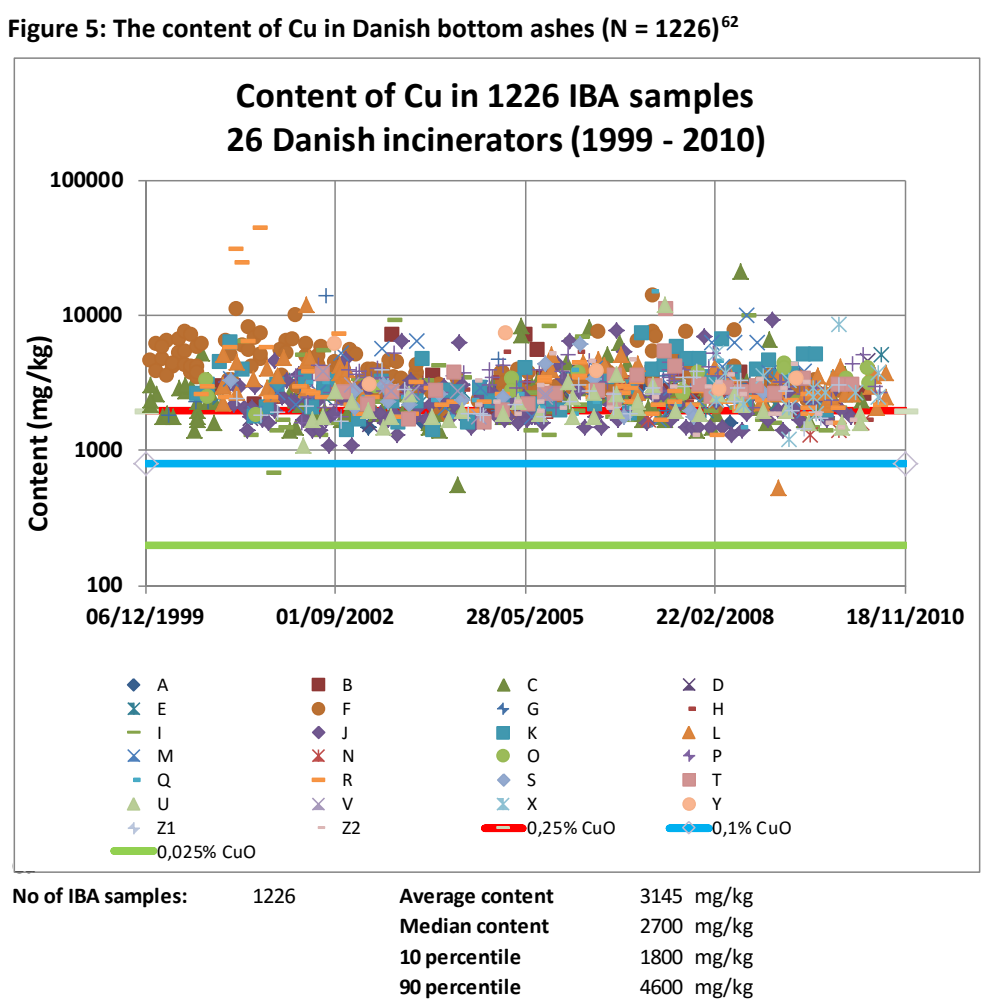

Source: (Hjelmar 2015).

Figure 6: The content of $\mathrm{Cu}$ in Danish bottom ashes $(\mathrm{N}=1226)^{63}$

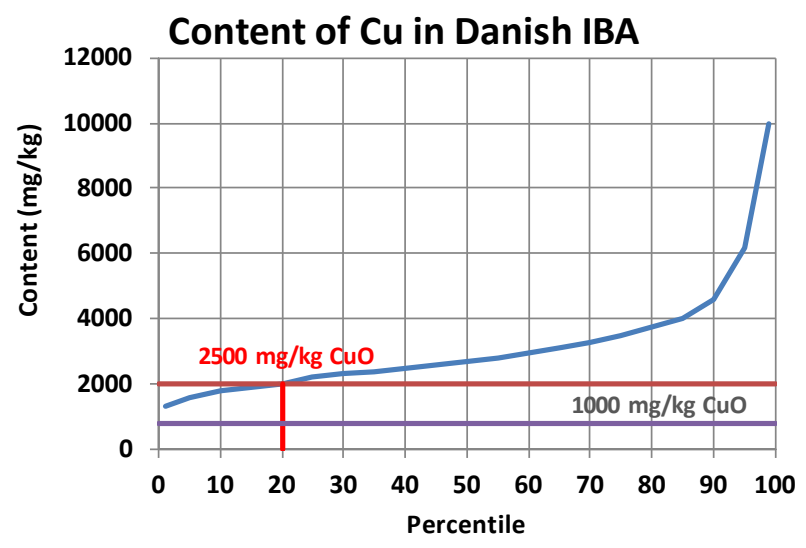

Source: (Hjelmar 2015).

62 Data presented by Ole Hjelmar, Danish Waste Solutions ApS, at the workshop in Espoo, 12 May 2015.

${ }^{63}$ Data presented by Ole Hjelmar, Danish Waste Solutions ApS, at the workshop in Espoo, 12 May 2015. 


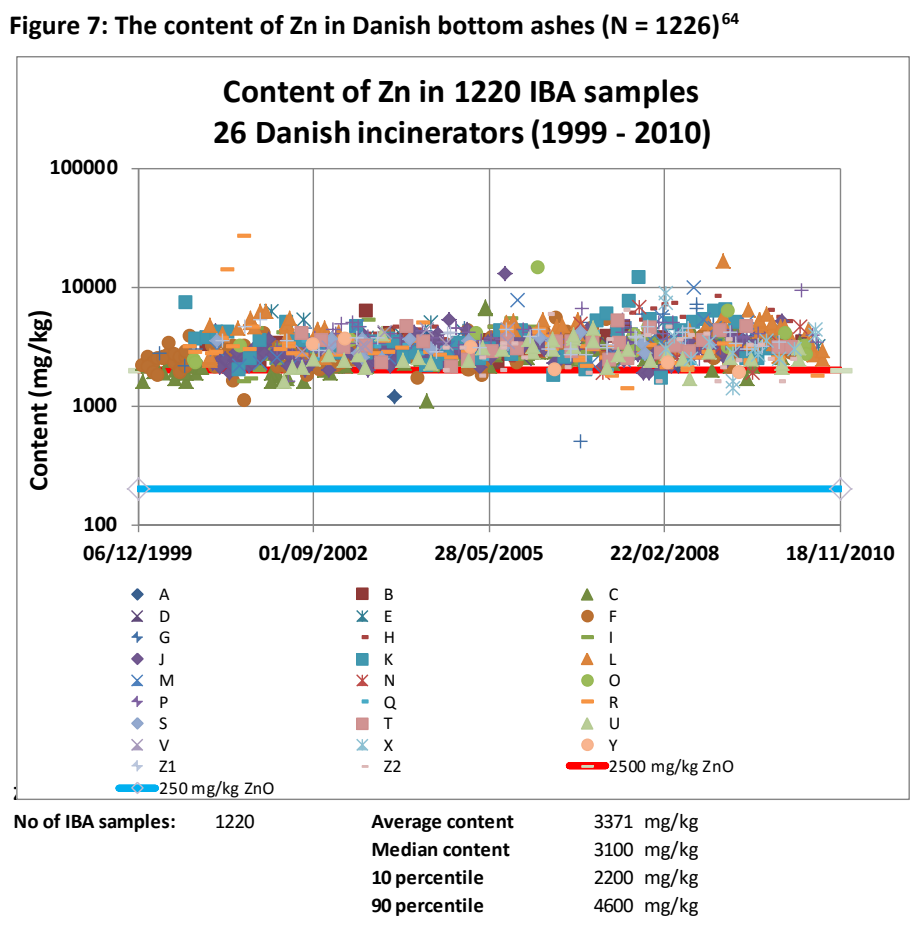

Source: (Hjelmar 2015).

Figure 8: The content of $\mathrm{Zn}$ in Danish bottom ashes $(\mathrm{N}=1226)^{65}$

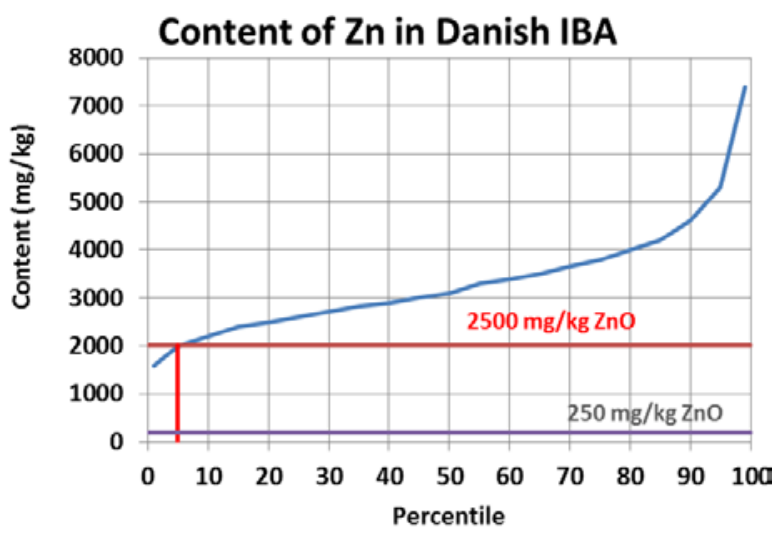

Source: (Hjelmar 2015).

${ }^{64}$ Data presented by Ole Hjelmar, Danish Waste Solutions ApS, at the workshop in Espoo on 12 May 2015

${ }^{65}$ Data presented by Ole Hjelmar, Danish Waste Solutions ApS, at the workshop in Espoo on 12 May 2015. 


\subsubsection{Conclusions concerning the use of calculation methods}

There are several challenges linked to the use of the calculation formulas. The basic data needed for the assessment are the same for all methods and calculation formulas are simple mathematical relationships in all cases. The main problem concerns the difficulties to determine the speciation of the hazardous substances and their classification. A worst case approach easily leads to an overestimation of the hazards which in turn may lead to a need for additional laborious and costly assessments (e.g. leaching tests/speciation calculations/biotests).

Harmonised $\mathrm{M}$ factors have currently been defined only for a limited number of substances in Annex VI of the CLP Regulation. However, the assessment of $\mathrm{M}$ factors are mandatory under REACH and the CLP (Classification and labelling Inventory and REACH registrations) and the publication of harmonised $\mathrm{M}$ factors will most likely continue for several years under the Chemicals legislation, based on scientific evidence. Thus, the influence of $M$ factors on waste management under the CLP may be severely underestimated if it is based solely on the already existing harmonised M factors in Annex VI. The assessment should include a prediction of reasonable (generic) M-factors for substances which are likely to have $\mathrm{M}$ factors within the next years, and the potential influence this may have on the classification of wastes as ecotoxic and therefore on future waste management should be evaluated. For example, the $\mathrm{M}$ factors of metals/metal ions would very likely have a significant influence on waste classification, and should be included in an assessment of consequences. There is already a substantial amount of registered classifications and scientific information available on the $\mathrm{LC}_{50}$-values of metals and metal ions which can be used to estimate the possible $\mathrm{M}$ factors for these substances (although it may require a substantial amount of work to identify "correct" $\mathrm{LC}_{50}$ values). A list of reasonable worst case $\mathrm{M}$ factors for several inorganic substances has been published in the report on the HP14 consultant study, see Appendix 6.66

The concept of using $M$ factors in method 2 and 4 introduces a substantial uncertainty into the classification of waste and may potentially lead to high or low limit values for hazard classification, depending on how M-factors are assigned, and in turn affect some important waste streams. If a generic M factor of 10 is assumed, summation methods 1, 2

${ }^{66}$ Study to assess the impacts of different classification approaches for hazard property H 14 on selected waste streams (Bio Deloitte \& Ineris, France), Final report, October 2015. http://ec.europa.eu/environment/waste/ studies/pdf/H14.pdf 
and 4 will give similar classification with a concentration limit at $0.25 \%$ $(2,500 \mathrm{mg} / \mathrm{kg})$ for single ingredients classified according to H410. The cut-off criteria applied in Method 2 will give a somewhat lower fraction of waste classified as hazardous compared to Method 1 and 4 for wastes with many ingredients classified according to H410. A generic M factor of 10 seems rational for many elements that fulfil these conditions (e.g. $\mathrm{Cu}, \mathrm{Pb}, \mathrm{Zn}, \mathrm{As}, \mathrm{CrVI})$. It thus seems likely that Method 1 and Method 2 will give a similar although not identical outcomes in terms of the amounts of waste classified as hazardous. Examples of critical waste streams are ashes and contaminated soils. Since the introduction of $\mathrm{M}$ factors is fairly novel in chemical legislation there are still limited experience and some lack of consensus on the assignment of $M$ factors and little or no experience concerning the consequences of using them in waste management.

All the methods are sensitive to the speciation of hazardous substances in the waste. Method 2 and Method 4 both require knowledge of M-factors which distinguishes them from Method 1 and 3.

The principal methodology applied in Method 2 is in full alignment with the CLP and other harmonised legislation, ${ }^{67}$ which enables direct use of information generated under REACH and CLP and the application of the bridging principle. This is in contrast to Method 4 which, although including $\mathrm{M}$ factors, is lacking many of the concepts and principles applied under the CLP (e.g. it does account for acute toxicity). Compared with all the other methods, Method 2 has the practical advantage of including the cutoff values supported by the CLP.

Method 1 is in alignment with the methodology in older versions of the repealed DPD except for the lack of the use of cut offs. The outcome of Method 1 and Method 2 is likely to be similar in practice. Method 3 is not aligned with any of the methods applied now or previously under the chemicals legislation or in member states and will generate larger amounts of hazardous waste compared to the current situation.

Finally, a comparison of Method 1 to Method 2 indicates that the methodology applied in Method 2 would be advantageous in the long term perspective from the perspective of consistency with other harmonised legislation. Method 1 most likely would lead to less uncertainty associated with the use of M-factors which is valuable in a short term perspective. Whether a long-term or a short-term perspective is preferable is a political decision.

\footnotetext{
${ }^{67}$ The CLP includes additional criteria to indicate chronic hazard, e.g. equation 4 in chapter 5.2.2, the fundamental principles for the assessment are however the same.
} 
A harmonised classification would be enhanced if generic hazard codes for elements and critical substances in waste (including $M$ factors if they are to be used) could be developed at European level. Harmonisation would also improve if agreement could be reached on the appropriate analytical methods. Analytical methods that represent the available content rather than the total content might improve the performance of the summation methods.

\subsection{Use of biotest in assessment of HP 14}

\subsubsection{The biotests proposed for assessment}

In the CLP there are references to test methods and criteria for assessment and classification of ecotoxic properties. The classification in the CLP is based only on aquatic biotests, not terrestrial tests (see 5.1). For the performance of the aquatic biotests, test eluates are prepared according to the T/D protocol or similar (see 5.2.1 and Method C in Table 15).

A French/German test method for waste hazard classification based on use of an EN 14735 developed for waste has been put forward in the consultant HP14-study (Method A in Table 5.6).68 In contrast to the CLP, CEN standards for wastes recommend an $\mathrm{L} / \mathrm{S}$ ratio of $10 \mathrm{l} / \mathrm{kg}$ and leaching at the inherent $\mathrm{pH}$ of the material. A testing scheme representing a compromise between the EN standards and the CLP requirements has been evaluated by Stiernström et al. (Method B in Table 15). ${ }^{69}$

\footnotetext{
${ }^{68}$ Study to assess the impacts of different classification approaches for hazard property H 14 on selected waste streams (Bio Deloitte \& Ineris, France), 2014-2015.

${ }^{69}$ Stiernström, S., Enell A, Wik O, Hemström K, Breitholtz M., 2014a. Influence of leaching conditions for ecotoxicological classification of ash. Waste Management 34(2), 421-429.
} 


\begin{tabular}{|c|c|c|c|}
\hline Method & A & B & C (T/D protocol) \\
\hline $\begin{array}{l}\text { Water-accommodated } \\
\text { fraction }(\mathrm{WAF})^{70}\end{array}$ & $0.1 \mathrm{~kg} / \mathrm{l}$ & $1 \mathrm{~g} / \mathrm{l}$ & $1-100 \mathrm{mg} / \mathrm{l}$ \\
\hline $\mathrm{L} / \mathrm{S}(\mathrm{I} / \mathrm{kg})$ & 10 & 1,000 & $1,000,000-10,000$ \\
\hline $\mathrm{pH}$ & Waste generated $\mathrm{pH}$ & 5.5-8.5 pHstat & $5.5-8.5$ ( $\mathrm{H} 2 \mathrm{CO} 3$ buffer $)$ \\
\hline Particle size & $<4 \mathrm{~mm}$ & $<0.125 \mathrm{~mm}$ & $<1 \mathrm{~mm}$ \\
\hline Leachate & Deionized water & $\begin{array}{l}\text { Deionized water } 0.001 \mathrm{M} \\
\mathrm{CaCl} 2\end{array}$ & $\begin{array}{l}\text { ISO } 6341 \text { fresh water or bi- } \\
\text { otest media }\end{array}$ \\
\hline Removal of solid phase & Filtration & Filtration or centrifugation & Filtration or centrifugation \\
\hline Dilution prior biotest & 10 & 2 & - \\
\hline Leaching time & 24 hours & 24 hours & 48 hours -28 days \\
\hline $\begin{array}{l}\text { Guidelines and } \\
\text { references }\end{array}$ & EN 14735 , EN $12457-2$ & $\begin{array}{l}\text { Based on CEN/TS } 14735 \\
\text { and NT ENVIR } 003 \\
\text { Nordtest, } 1995\end{array}$ & OECD 2001, OECD 2002 \\
\hline $\begin{array}{l}\text { Interpretation (for me- } \\
\text { thod A and B no defini- } \\
\text { tive criteria has been set) }\end{array}$ & $\begin{array}{l}50 \% \text { affected popula- } \\
\text { tion at a dilution of } \\
10 \% \text { of eluate }\end{array}$ & $\begin{array}{l}\text { No effect at a dilution of } \\
50 \% \text { of eluate }\end{array}$ & $\begin{array}{l}\text { Comparison to ERV } \\
\text { (or biotesting for } \\
\text { confirmation) }\end{array}$ \\
\hline
\end{tabular}

It should be noted that method A presented in Table 15 represent choices of $\mathrm{L} / \mathrm{S}$ and $\mathrm{pH}$ that are normally used for risk assessment related to landfilling or recycling and hence refer to certain exposure scenarios. Also the T/D protocol (Method C) does, in fact, represent choices of L/S and $\mathrm{pH}$ that reflect a type of exposure scenarios. The assessment based on application of these methods is therefore to a certain extent scenario related rather than representing truly intrinsic properties of the waste.

The French/German test batteries also include terrestrial tests. They are not discussed here in detail due to the fact that there are no criteria for assessments of terrestrial test in the CLP and consequently no relationships to the hazard statement codes used in the summation formulas that define the hazard classification of HP14.

${ }^{70}$ Water accommodate fraction is the terminology used under CLP to account for solid /liquid ratios used in various test conditions while $\mathrm{L} / \mathrm{S}$-ratios are used under $\mathrm{CEN}$-standards $(1 / \mathrm{WAF}=\mathrm{L} / \mathrm{S})$. 


\subsubsection{Experience and applicability of the proposed biotest methods}

The test methods in Table 15 have been evaluated within the framework of the project by either testing (methods A and B, Appendices 1,2 ) or geochemical modelling (method A, B and C, Appendix 4). The results from the two different evaluations conform substantially. Test conditions are critical for hazard classification, specifically the $\mathrm{L} / \mathrm{S}$ ratio and the $\mathrm{pH}$. The standardised leaching test for waste at $\mathrm{L} / \mathrm{S}=10 \mathrm{l} / \mathrm{kg}$ (Method A in Table 15) generates results for non-toxic elements, such as $\mathrm{Ca}$ and $\mathrm{K}$ that could trigger hazardous classification. ${ }^{71}$ For alkaline wastes containing toxic elements, such as $\mathrm{Zn}$ and $\mathrm{Cu}$, these standardised methods without $\mathrm{pH}$ adjustment underestimate the hazard due a leaching minimum at elevated $\mathrm{pH}$ value ( $\mathrm{pH}$ above 8). Overall, it can be concluded that the available standardised leaching tests for waste (Method A) generate results that are not applicable to hazard classification.

Leaching performed at $\mathrm{L} / \mathrm{S}=1,000 \mathrm{l} / \mathrm{kg}$ and with $\mathrm{pH}$ control (Method B), will prevent erroneous classification for non-toxic elements such as Ca and $\mathrm{K}$ but will substantially overestimate the hazard associated with toxic elements such as Zn and Cu compared with the CLP criteria. However, methods offered under the CLP (Method C) are not well suited for regular monitoring of waste hazard properties due to operational issues (difficulties to get representative test portions for testing of heterogenous waste at $\mathrm{L} / \mathrm{S}$ values of $1,000,000-10,000 \mathrm{l} / \mathrm{kg}$ ). Test methods, however, seems to have a potential to perform much better than the summation methods (see section 5.3) in terms of both accuracy and precision.

Both the execution and the results of aquatic biotesting of samples of waste raised several questions, and further development of tests protocols for hazardous assessment of waste is thus strongly recommended prior to any possible operational implementation. In a biotesting study of ash and concrete waste the following observations were made (see also Appendix 1):

- All test eluates from ashes and also concrete waste generated by Method A were alkaline. The $\mathrm{pH}$ of the test eluates were adjusted prior to testing, which means that the composition of the eluate was not necessarily the same as the eluate collected in the leaching test (e.g. substances may precipitate in the $\mathrm{pH}$ adjustment). Discussion is needed on the applicability of biotests for alkaline waste.

\footnotetext{
${ }^{71}$ Stiernström, Wik 0, Bendz D. Critical evaluation of methods for hazard classification of waste ecotoxic properties, Sardinia Conference 2015.
} 
- No pH-adjustments were needed for the eluates prepared according to Method $\mathrm{B}$ since $\mathrm{pH}$ is adjusted during leaching (pH-static test).

- The results from Method A and the Method B protocol gave different results for the ecotoxicity, as expected; for example were the results for fly ash from gasification of solid recovered fuel (SRF) and recycled wood contradicting. Method B shows better agreement with summation methods based on the total content of $\mathrm{Pb}, \mathrm{Cu}$ and $\mathrm{Zn}$ in the ashes. This pinpoints the need for further analysis of factors influencing the results.

In a biotesting study of wastewater sludge, the following observations were made (see also Appendix 2):

- All sludge samples tested with the proposed aquatic tests by Method A either failed (i.e. killed the test organisms as an artifact) or were not suitable for at least one of the three water environment test. There is a clear need for additional clarifications related to the applicability of ecotoxic tests for organic and biodegradable wastes and materials.

- Organic wastes like sewage sludge generally have high contents of easily degradable organic matter. The Daphnia magna mobility test is not applicable since the low oxygen level in sample eluates resulting from biodegradation of high organic matter content kills the Daphnia magna, thus preventing the use of the test.

\subsubsection{Conclusions concerning the use of biotests}

The CLP and REACH test procedures was originally developed for pure substances and mixtures of pure substances. It is difficult to apply these methods to heterogeneous waste materials of complicated composition consisting of mixtures of numerous substances which may interact to modify the toxic effects. In order to provide a robust classification system for waste with respect to ecotoxicity, it may be necessary to deviate somewhat from the total harmonisation with the CLP and REACH.

Concerning the preparation of eluate for ecotoxicity testing, it should be noted that a requirement of full harmonisation with the CLP would rule out the use of eluates produced by standardised leaching tests (e.g. EN 12457) at $\mathrm{L} / \mathrm{S}=10 \mathrm{l} / \mathrm{kg}$. There is no standardised CEN test method for waste available today that meets the leaching scenarios applied in the assessment of ecotoxic properties under CLP. 
Some large waste streams, especially MSWI bottom ashes are likely to be subjected to further testing, because the metal concentrations exceed the concentration limits when applying the proposed calculation methods and a conservative generic assessment. Based on the observed results in the testing of several waste materials, several questions on both test performance and interpretation came up. It seems therefore too early to introduce biotest methods for waste classification. The CLP methods (T/D protocol) are not well suited for assessment of waste hazard properties due to operational/practical issues. Methods based on leaching and ecotoxicological reference values (e.g T/D protocol), however, seems to have the potential to perform much better than both the summation methods and ecotoxicity testing in terms of both accuracy and precision. Substantial further developments are required if indeed biotest methods are to be applied to waste classification. It should be stressed that the ecotxicological reference values $\left(\mathrm{EC}_{50}\right.$ or NOEC values) for metal ions developed under the CLP are not valid as endpoints if the test conditions $(\mathrm{L} / \mathrm{S}$ or $\mathrm{pH})$ are different from those used in the T/D protocol (like L/S = 10 l/kg in EN 12457).

The following questions have surfaced:

- Which are key recipients to be protected in this framework?

- And what is the waste characteristic property we are trying to measure with ecotoxity tests in this context?

- Are ecotoxity tests always indicating these properties?

- Several tests are proposed in the protocols. Are all tests to be passed as in the CLP? In the Finnish study it was noted that the chance of being classified as hazardous increases (in an unsystematic way) with the number of different tests applied.

There is no method available today that fulfils the requirements on a test method suitable for waste. 


\title{
6. Implications of the revised waste classification legislation on the management of selected waste streams
}

\begin{abstract}
Waste classification and related issues significantly influence the entire treatment and utilisation chain of waste. Potential changes in classification have a major impact on the status and acceptability of waste in the recycling market and especially in utilisation. In this section, some critical waste streams with mirror entries which might be classified as hazardous based on HP4, HP8 and/or HP14 are identified. There are no changes in legislation concerning HP4/HP8, but there have been unclarities in practice on how to assess these properties. The current LoW is thus not aligned with potential waste HP4/HP8 properties associated with high $\mathrm{pH}$. Focus is on wastes that are generated in large amount and currently extensively recycled or have a high recycling potential. The implications of the classification on legislation were discussed in section 1.3.
\end{abstract}

Table 16: The following waste streams are considered

\begin{tabular}{ll}
\hline EWC code & Waste stream \\
$100116^{*}, 100117$ & $\begin{array}{l}\text { Wastes from power stations and other combustion plants: Fly ash from } \\
\text { co-incineration }\end{array}$ \\
$\begin{array}{l}170101,170106^{*}, 170107 \\
(101314,191212)\end{array}$ & $\begin{array}{l}\text { Concrete waste and mixtures of concrete, bricks, tiles and ceramics } \\
170503^{*}, 170504\end{array}$ \\
$190111^{*}, 190112$ & Soil and stones \\
$190805,190811,190813$ & Municipal solid waste incinerator (MSWI) bottom ash \\
\hline
\end{tabular}




\subsection{Construction \& demolition waste: concrete waste}

Wastes containing $10 \%$ or more $\mathrm{CaO} / \mathrm{Ca}(\mathrm{OH})_{2}$ are to be classified as hazardous wastes based on HP4/HP8. For concrete waste the alkalinity is a natural property. Concrete waste contains varying concentrations of $\mathrm{CaO}$ and $\mathrm{Ca}(\mathrm{OH})_{2}$ which among other compounds are causing alkalinity. As the exact elemental composition of waste materials like concrete waste is not generally known and the mineralogical determination is challenging, it is in most cases only possible to assume the compound form of specific elements of interest. It is, however, known that many calcium compounds are occurring in concrete as silicates and not as alkalinity causing compounds. This can unfortunately not be verified accurately enough with reasonable resources from results of total calcium concentration analysis.

Many construction products have an initial high $\mathrm{pH}$ value (above 12). For example, fresh concrete has a pH above 12.5 , and if tested in a crushed state, typically above 13 . In recycling, such construction products (e.g. crushed concrete, IBA) often undergo carbonation upon exposure to and uptake of carbon dioxide from atmospheric air, which typically lowers the $\mathrm{pH}$ on contact with water to a level (8 to 10 ) which is generally more favourable in terms of overall release of metals and trace elements (and direct toxic $\mathrm{pH}$ effects). Under these conditions the materials still retains some of the buffering capacity towards further acidification (e.g. by acid rain), particularly because the carbonation starts on the surface of the aggregates and moves slowly inwards.

The carbonation or $\mathrm{CO}_{2}$ uptake leads to the formation of carbonate compounds from hydroxides. The carbonation process is a long term process. As mentioned above, the reaction happens at the surface of the waste. Large particles of concrete which have been aged and carbonated will typically generate $\mathrm{pH}$ values below 11 in contact with water. However, if the waste material is ground or further crushed during storage, handling and disposal or use (or if it is crushed to be tested in the alkali reserve test, see section 4.2), new surfaces will be available and the $\mathrm{pH}$ of eluate from testing of the waste may well be alkaline with $\mathrm{pH}$ over 11 , and there is real risk that such crushed waste might be triggering HP4/HP8 criteria for hazardous classification.

The environmental impacts of concrete waste from use of construction and demolition are often considered low. Concrete waste has generally a low content of metals, although the environmental properties of crushed concrete may vary between countries and is not really well described. Concrete waste may contain a variety of substances that has been added during 
the production of the cement, the production of the concrete and during the use of concrete in houses or other constructions (e.g. paint, PCB, hydrocarbons). Concrete waste has been regarded in many countries as potential candidate for end-of-waste to replace natural aggregate in earth constructions. Such a step would require a comprehensive assessment of the potential environmental impacts from various uses of a broad range of crushed concrete aggregates of various origins. The European Commission has specifically defined concrete \& demolition waste as one priority waste stream, because of the huge amount generated and the high recovery potential of valuable raw material.

\section{Generation and management}

In Europe it is estimated that around 461 Mill. tonnes of construction and demolition waste excluding soil materials (which is approximately $32 \%$ of all waste produced) is generated. ${ }^{72}$ The major part of this waste stream is concrete and mixtures of concrete, bricks, tiles and ceramics. The recent figures reported for concrete waste in a Nordic ENCORT report are presented in Table 17.

Table 17: Amounts of generated mineral C\&D waste in Nordic countries ${ }^{73}$

\begin{tabular}{ll} 
Country & Waste amounts \\
Denmark & $1,362 \mathrm{kt} \mathrm{(2009)}$ \\
Finland & $700-1,000 \mathrm{kt} \mathrm{(2011)}$ \\
Norway & $640 \mathrm{kt}(2011)$ \\
Sweden & $1,030 \mathrm{kt} \mathrm{(2011)}$ \\
\hline
\end{tabular}

Source: ENCORT, 2014.

Currently, the waste is to a large extent recycled in earth constructions and is replacing natural aggregates in earth construction. Today research is focusing on recycling of concrete waste in cement (replacement of clinker) or in new concrete production after pre-treatment process (milling, removal of fine fractions). Another possibility, not yet widely used, is the reuse of concrete elements, e.g. in constructions.

\footnotetext{
72 European Commission-DG ENV (2011) "Management of Construction and Demolition Waste in EU27". Final Report elaborated by BIO Intelligence Service.

73 Arm M., Wik O., Engelsen C.J., Erlandsson M., Sundqvist J-O., Oberender A., Hjelmar O. and Wahlström M. (2014). ENCORT-CDW - Evaluation of the European recovery target for construction and demolition waste. Nordic Working Papers 2014:916 http://urn.kb.se/resolve?urn=urn:nbn:se:norden:org:diva-3200. DOI:10.6027/NA2014-916
} 


\subsection{MSWI bottom ash}

Bottom ash contains typically heavy metals like $\mathrm{Zn}$ and $\mathrm{Cu}$ and might be subjected to HP14 evaluation based on this even though many elements appear as silicates or mixed sintered amorphous minerals. As the exact elemental composition of waste materials like bottom ashes is not always known (however, see Appendix 1) and assessment of the mineralogical determination is extremely challenging, one usually only assumes that the elemental composition e.g. elements in wastes from thermal processes appear as oxides. Although MSWI bottom ash (BA) is generally classified as non-hazardous waste in all the Nordic countries, the conservative summation of the metals in their simple assumed forms (e.g. $\mathrm{CuO}$ and $\mathrm{ZnO}$ ) and the potential use of M factors in calculation formulas for HP14 will probably lead to classifications as a hazardous waste against HP14.

\section{Generation and management}

Waste incineration is the major treatment method for municipal waste in many European countries, including the Nordic countries. In the waste incineration process, about $80 \%$ of the feedstock is transferred into the flue gas, while remaining $20 \%$ is transferred into the bottom ash. The amounts of MSWI residues generated in Nordic countries are shown in Table 18.

Table 18: Amounts of generated MSWI ashes in the Nordic countries

\begin{tabular}{lllll} 
Waste type & Denmark & Finland & Norway & Sweden \\
$\begin{array}{l}\text { Wastes from incineration } \\
\text { and pyrolysis of waste, bot- } \\
\text { tom ash, slag }\end{array}$ & $\begin{array}{l}498 \text { ktonnes } \\
(2006)\end{array}$ & $\begin{array}{l}270 \text { ktonnes } \\
(2011)\end{array}$ & $\begin{array}{l}150-200 \text { ktonnes } \\
\text { (2009) }\end{array}$ & $\begin{array}{l}\text { 693 ktonnes } \\
\text { (2009) }\end{array}$ \\
\hline
\end{tabular}

Source: Hjelmar 2009, ${ }^{74}$ Korpijärvi $2011 .{ }^{75}$

Currently certain metals e.g. $\mathrm{Fe}, \mathrm{Cu}$ and $\mathrm{Al}$ are recovered mechanically from the bottom ash and the remaining ash is often used as an aggregate in earth constructions (road construction, car parks, roads in landfill areas). The potential extraction of precious metals has raised some interest, but is still not done.

${ }^{74}$ Hjelmar, O., Wahlström, M., \& Laine-Ylijoki, J. 2009. Treatment methods for waste to be landfilled. Nordic Council of Ministers. TemaNord: 583.

75 Korpijärvi, K. 2011. VTT, Finland. Own data. 


\subsection{Ashes from renewable energy sources}

Fly ashes from co-combustion and co-incineration of diverse bio- and wastebased fuels often have very high $\mathrm{pH}$, especially when fresh, and when the share of wood is high. However, ageing and carbonisation reduces pH relatively quick to $\mathrm{pH}$ levels of 11 and lower. Wood-based ashes also contain varying concentrations of $\mathrm{CaO}$ and $\mathrm{Ca}(\mathrm{OH})_{2}$ among other compounds, both alkaline and earth alkaline metals, causing alkalinity. For biomass waste the alkalinity is to a certain point a natural property arising from the bio-based fuels, but in some cases calcium compounds are also used as reagents in air pollution control systems of combustion plants. However, many calcium and other alkaline compounds are occurring in ashes as silicates and carbonates, but the exact compound composition of ashes is usually not known and the mineralogical determination is challenging.

The combustion conditions and the type of fuel influence significantly the fly ash quality. In some cases the resulting ashes may have also elevated contents of $\mathrm{Cr}, \mathrm{Pb}, \mathrm{Cd}$ and $\mathrm{Zn}$. This means that in this context many fly ashes might end up to HP evaluation against both HP4/8 and HP14.

Ashes from combustion of pure wood waste $\left(\begin{array}{ll}10 & 0103\end{array}\right)$ do not have a mirror entry and will therefore not be subjected to an assessment. This highlights the importance of correct selection of the waste code from the European waste list.

\section{Generation and management}

The use of biomass and wood chips in CHP (combined heat and power) production and separate heat production will be increased in the Nordic countries as a consequence of the Renewable Energy Directive. This change in fuel will significantly increase the generation of biofuel ashes.

Table 19: Amounts of wood ash generated (ktonnes/year)

\begin{tabular}{lr} 
& Waste amounts (ktonnes/year) \\
Denmark & $>32$ \\
Finland & 100 \\
Norway & 75 \\
Sweden & 155 \\
\hline
\end{tabular}

Source: Kema-report, $2012 .^{76}$

\footnotetext{
${ }^{76}$ van Eijk, R.J., Obernberger, I. \& Supancic, K. 2012. Options for increased utilization of ash from biomass combustion and co-firing. IEA Bioenergy Task 32. Deliverable D4. Kema-report.
} 
Biomass ashes are currently used as fertilizers e.g. on forest soils, for which also regulations and guidelines have been given. Typically, utilisation criteria for fertilizer use are set on minimum content and availability of nutrients and maximum content of heavy metals. Recommendations are given for the Ca content as a neutralising component against acidity. The classification of these ashes in the LoW under an absolute non-hazardous entry (10 0103 ) is clearly not in compliance with HP4 and possibly neither with HP8 (due to the result of the alkali reserve test).

To some extent ashes are used also as a filling material in earth constructions (walls, embankments). In addition a significant part of ash is disposed at landfills for non-hazardous waste.

\subsection{Contaminated soil}

Excavated contaminated soils contain usually miscellaneous pollutants e.g. metals, $\mathrm{PAHs},{ }^{77}$ mineral oils, $\mathrm{PCBs}$ and are therefore often inevitably subjected to HP14 evaluation. Therefore the assessment procedure both for sampling and interpretation of results creates challenges in the possible evaluation of HP14 for contaminated soils. In the future the possible use of M-factors is likely to lead to lowered criteria for some highly toxic substances.

\section{Generation and management}

Soil waste is the major waste stream in several Nordic countries, especially in Finland. Typical contaminants are As, $\mathrm{Cr}, \mathrm{Zn}, \mathrm{Cu}, \mathrm{Ni}, \mathrm{Pb}, \mathrm{PCB}$, oil and pesticides. The waste is typically heterogeneous and may contain other waste fractions. A specific problem relates to naturally occurring high concentrations of metals in soil when the soil is excavated.

\footnotetext{
${ }^{77}$ According to the EU Court of Justice Decision C-1/03: Non-excavated soil is waste. However, in the Waste frame directive (WFD), the non-excavated soil has been left outside the scope of WFD.
} 
Table 20: Amounts of non-hazardous soil waste generated in $\mathbf{2 0 1 2 ^ { 7 8 }}$

\begin{tabular}{lr} 
& Non-hazardous soil waste amounts (Million tonnes) \\
Denmark & 2.3 \\
Finland & 14 \\
Norway & 3.9 \\
Sweden & 3.5 \\
\hline
\end{tabular}

Source: Soil waste generated in the construction sector, statistical data from a EU study and Eurostat (see footnote 76).

Excavated contaminated soil can be treated on site, often with the aim to improve the conditions for on-site recovery of a fraction of the excavated soil. Off-site treatment of contaminated soil is the most common treatment e.g. by screening, washing, biological processes or thermal treatment. Today, the most common final disposal method for excavated soil is probably landfilling.

\subsection{Urban wastewater sludge}

Urban wastewater sludges are generally classified as non-hazardous (19 08 05). In Nordic countries their heavy metal concentrations are low reflecting requirements in national legislations with much lower limit values for heavy metals than in Sewage Sludge Directive. In addition to urban waste water many plants receive also industrial waste waters or septic tank waters, which makes mirror entries such as 1908 11* and 1908 $13^{*}$ possible and thereby subjects these sludges to HP evaluation, most likely against HP14. In case of elevated concentrations of inorganics or/and organics wastewater sludges need to be evaluated against HP14.

\section{Generation and management}

In the Eurostat statistics on sewage sludge, the latest most complete dataset on sludge production and disposal in the Nordic countries is from 2009. At that time, $0.21,0.14$ and 0.11 million tonnes of sewage sludge as dry solids were generated in Sweden, Finland and Denmark, respectively.79 Data for Iceland and Norway were not available. The utilisation and/or disposal routes for sludge vary by country. However, agricultural use together with composting and other applications, i.e. use as fertiliser

78 Source: http://ec.europa.eu/environ-ment/waste/studies/mixed_waste.htm (data for Denmark, Finland, Sweden) \& Eurostat for waste generated in 2012 (Norway)

79 Eurostat 2015. Database "Sewage sludge production and disposal” [env_ww_spd]. Extracted 29 April, 2015. 
or soil conditioner, represent the majority of sludge utilisation routes in all countries. Denmark relies also on incineration whereas in other Nordic countries sludge incineration was virtually not practised in 2008.

Potential changes in classification may have a major impact on the status of wastewater treatment sludges and on their acceptability in the recycling market and especially on the application in agriculture. For example, when taking into account the use of sludge as soil improvement or fertiliser, it can be estimated that in the Nordic countries the currently utilised sludge volume corresponds to approximately 390,000 tonnes of dry solids annually.

Further information on urban wastewater treatment sludge is given in Appendix 2. 


\section{Conclusions and recommendations in a Nordic context}

In the following, the conclusions and lessons learned from the study of the recently implemented changes to the EU regulation on hazard classification of waste and the report provided by a consultant (BiPRO) to assist the Commission in developing a guidance document on the definition and classification of waste are presented and a number of recommendations are offered with particular focus on Nordic conditions where relevant:

\subsection{The European List of Waste and waste codes}

There appears to be little or no published information on why a specific waste entry in LoW is regarded as absolute hazardous, absolute non-hazardous or a mirror entry (e.g. there is no information on or documentation of which are the specific hazard properties that render a certain waste entry absolute hazardous). This greatly complicates the use of the LoW and the associated legislation as a working tool, and if it was possible to find the specific reasons for (in particular) absolute classifications of specific waste streams as hazardous in terms of the HPs and Hazard Statements that has caused this classification, it could help focus and facilitate the classification procedure for a given relevant waste material. It would be of particular use in the case of mirror entries if the HPs and HSs that could potentially render a waste material hazardous could be identified in advance.

There is a lack of consistency between some entries on hazardous/non-hazardous waste in the European LoW and the hazard properties (e.g. several wastes classified as non-hazardous have properties that would render them hazardous based on the hazard properties).

The selection of a waste code (with or without mirror entries) from the European waste list is sometimes more critical than the actual hazardous properties of the waste. This is especially true in the case of classification of waste as hazardous HP4/HP8 due to elevated pH/alkaline 
reserve. Many wastes (e.g. slag from iron and steel manufacture (LoW entries 1002 01, 1002 02), fly ash from peat and untreated wood (entry 100103 )) exhibiting elevated $\mathrm{pH}$ that could trigger hazardous classification HP4/HP8 are registered as absolute non-hazardous waste entries in European list of waste. Others (e.g. bottom ashes from waste incineration $(1901$ 11*, 1901 12), ashes from co-combustion $(1001$ 16*, 1001 17), concrete waste and mixtures of concrete, bricks, tiles and ceramics (17 $0101,170106^{*}$ ), sludges from treatment of urban wastewater (19 08 05, $190811^{*}, 190813^{*}$ ) ) are registered as mirror entries and require assessment and possibly hazard classification. Whether the assignment of absolute non-hazardous or mirror entries is intentional or arbitrary in this context is far from clear. It is apparent that HP4/HP8 could have a major impact on the classification of significant quantities of waste, and the consequences of applying $\mathrm{pH}$ and alkalinity criteria for hazard classification have so far been overlooked. It should also be noted that there are discrepancies between the interpretation of mirror entries e.g. between the study report from BiPRO and similar guidance documents in the UK and Germany.

\subsection{Methods and tools for hazard assessment}

In contrast to the pure chemicals or the mixtures of pure chemicals for which the CLP was developed, wastes are typically complex, heterogeneous materials in which the characteristics are highly dependent on input materials used in processes or applications. The waste properties are therefore not constant and controlled as the case is for chemicals and products for which the key properties, functionality and impurities are regularly checked. Furthermore, waste characteristics may also change with time due to ageing processes (e.g. carbonisation, oxidation, reduction). Part of the waste composition is not even known. Sampling and testing of particularly heterogeneous waste materials need special attention. Test methods developed for chemicals are not necessarily applicable for practical reasons (e.g. it may not be possible to prepare representative test portions without incurring extensive efforts or costs). Not much has been published in scientific journals on appropriate test experiences in waste classification.

Waste classification through testing needs further guidance on the need for testing and on how to choose a test method for assessment of property. Also the expertise of the testing laboratories may vary a lot, especially in evaluation on how the data from waste origin can be used to 
set up the testing programme. One waste may be classified as hazardous in one country and as non-hazardous in another country. Common rules for waste classification on a practical level are needed, especially for waste streams that are shipped or traded from one country to another. Testing procedures that are not specified may lead to different results and interpretation of results. One important example in this context is the analysis of PCBs which constitutes a special problem because of the lack of guidance on the calculation of the total content from analysis of a limited number of congeners.

The current test methods used in the CLP are initially meant for chemicals, typically with known composition and a limited amount of constituents and minor components (impurities). However, as mentioned above, waste is often a very heterogeneous material with a complex composition typically containing numerous inorganic and/or organic substances. It is therefore a major challenge to apply the CLP to the classification of waste as non-hazardous or hazardous. The use of worst case approaches for metals may lead to over-cautious practices. Furthermore, suitable methods for identification and quantification of organic substances are often lacking, leading to over-emphasis of inorganics in the evaluation regardless of their true risks in the waste management chain. There are no guidelines on the chemical analysis or speciation of substances in mixtures in the CLP or the CLP Guidance. It is a field that must be developed under the waste legislation.

Assessment of waste based on test methods will be costly and may be difficult to implement for individual waste holders. For wastes regularly generated in the same process a joint assessment from different installations, as supported by assessment regulations of landfill criteria and REACH-registrations, could be a way forward. A requirement for such an approach would be that the waste can be identified as single streams with common characteristics within known boundaries (e.g. bottom ash from the incineration of municipal waste).

The determination of the true quantitative speciation of specific substances of wastes is extremely demanding compared to the determination of elemental composition - in practice often impossible. Analytical methods that represent the available content rather than the total content could perhaps improve the performance of the summation methods. The authors recommend the development of Nordic or European assessment protocols for key waste streams in order to reduce some of the discrepancies. Several standardised test methods have been developed for waste characterization in CEN/TC 292. These test methods need to be better introduced into the testing in relation to waste classification, because they 
have been developed especially for waste and in contrast to some of the methods described in the CLP, they provide guidance on preparation of test portions. Sample preparation has a significant influence on test results especially for multiphase materials.

The development of more harmonised classification procedures, including generic hazard statement codes for elements and critical substances and harmonised $\mathrm{M}$ factors (if required) at a European level would greatly reduce the efforts required in waste classification and lead to more uniform results. Also harmonisation of the methodology - both concerning substances to be considered for typical waste materials and the selection of appropriate analytical method for the assessments would reduce efforts and improve results.

A tiered approach to the hazard assessment of waste has been described and is recommended by the authors. The performance of joint (Nordic) assessment of waste generated from the same processes by different waste producers or managers is also suggested.

Geochemical modelling based on leaching tests is a powerful tool for the speciation of metals in test media and is included in the proposed tiered approach. From the substances present, their concentration and the relevant $\mathrm{pH}$ value, and knowledge of the substances solubility/release under the specific conditions, the type and the speciation in the eluate can be estimated. It may be used to assess whether or not a specific mineral (substance) of interest controlling the solubility of a given element is likely to be present in a given type of waste. Such assessments should to the extent possible be supported by other measurements such as, for example, X-ray diffraction analysis. Over the past ten years several scientific studies have been published on the use of speciation for getting understanding of behaviour of wastes at different test conditions. However, especially the expertise of the modellers and data on species included in the model database are crucial. The costs of geochemical modelling depend on the complexity of the waste. Further development is needed in order to expand the current practises into the field of hazard assessment. 


\subsection{Specific HP4/HP8 issues}

Elevated $\mathrm{pH}$ is normally not considered a property that triggers measures to detoxify or ensure a non-toxic materials cycle. ${ }^{80}$ It should be taken into account that exposure to atmospheric carbon dioxide often will reduce the $\mathrm{pH}$ to values between 8 and 10 within a relatively short timeframe. It could therefore be reasonable to exempt such properties from triggering hazardous waste classification. One way to harmonize the assessment and classification with respect to high $\mathrm{pH}$ and alkalinity and HP4/HP8 and remove inconsistencies in the LoW could be an amendment of Annex III for ashes, slags, sewage sludges and concrete waste. This amendment should mean that elevated $\mathrm{pH} /$ alkalinity alone should not cause hazardous classification. Such an approach would be a departure from a harmonised assessment between CLP and hazardous waste classification. But the deviation would be easy to monitor and measure and in line with deviations already implemented for HPs 4, 6, 8, and 13 in Annex III.

If such exemptions are not possible, the use of the CEN methods (especially $\mathrm{pH}$ dependence test with continuous $\mathrm{pH}$-control) is recommended by the authors for the determination of the alkali reserve in waste. The content of alkaline substances to be considered in the assessment correlates with $\mathrm{pH}$ and the assessment based on alkali reserve is most practical.

For some waste types, fly ashes from wood incineration, bottom ash from MSWI, concrete waste and lime stabilised wastewater sludges, high $\mathrm{pH}$ is generally the only reasonable cause for the waste to show irritant properties. Based on knowledge about the origin, production and chemical composition, the presence of other types of substances in concentrations that can trigger classification as irritating or corrosive can be assessed based on limits given in Annex III. The authors do not see the in vitro test as necessary for these wastes if HP4/HP8 properties can be excluded based on tests on $\mathrm{pH}$ and the alkali reserve. This is in line with the classification of wastes belonging to entry 100103 in the LoW as absolute non-hazardous.

${ }^{80} \mathrm{High} \mathrm{pH}$ or alkalinity does not trigger restrictions or substitution under the Swedish BASTA (http://www.bastaonline.se/about-basta/about-basta/?lang=en) or Swedish Chemicals Agency PRIO (http://www.kemi.se/en/prio-start) frameworks. 


\subsection{Specific HP 14 issues}

For wastes with mirror entries, especially the hazardous property HP 14 (ecotoxicity) is challenging and a critical property for many recyclable waste streams. Therefore, the final decisions about HP 14 (ecotoxicity) require comprehensive short and long term consequence analysis with regard to waste recycling and circular economy. Calculation formulas have been proposed for the assessment of the HP 14 hazard statements. Some proposed formulas also contain so called $\mathrm{M}$ factors for toxic substances. However, a wide-ranging and in-depth knowledge about the consequences of the use of $\mathrm{M}$ factors in calculation formulas for HP 14 (ecotoxicity) is still lacking. In the future, $\mathrm{M}$ factors will be developed for several substances and an estimation based on the current list of published M factors in Annex VI of the CLP will underestimate the consequences significantly. Consequences on waste management and recycling without assigning correct $\mathrm{M}$ factors cannot be predicted nor foreseen. There is also a risk that HP 14 assessment turns out to be laborious/costly and leading to non-comparable results between experts and countries. Based on experience in this project, it seems also too early to introduce leaching or ecotoxicity tests for waste classification as an alternative to the calculation formulas (if such tests should indeed be introduced at all). The EU Commission has proposed four different calculation methods (Methods 1 to 4 ) which are all sensitive to the speciation of hazardous substances in the waste. Method 2 and Method 4 both require knowledge of $M$ factors which distinguishes them from Method 1 and 3.

Method 2 is in alignment with the CLP and other harmonised legislation, which enables direct use of information generated under REACH and CLP and the application of the bridging principle in contrast to Method 4 which does not account for acute toxicity.

Method 1 is in alignment with the practises performed in several member states today while Method 3 most likely will generate larger amounts of hazardous waste. Furthermore Method 1 is to some degree (but lacking the $\mathrm{M}$ factors) in alignment with the CLP (and the repealed DPD) while Method 3 deviates in a decisive way by assessing the hazard statements independently one by one.

Finally, a comparison of Method 1 to Method 2 indicates that Method 2 with full alignment with the CLP (and other legislation which share its assessment criteria) would be advantageous in the long term perspective from the perspective of consistency with chemicals legislation while Method 1 most likely would lead to less uncertainty and less change in the current situation which is valuable in a short term perspective. Whether a long-term or a shortterm perspective is preferable is a political decision. 


\section{Sammanfattning}

Avfall klassificeras endera som farliga eller icke-farliga i europeisk lagstiftning. Farligt avfall är ett avfall som på grund av sina inre kemiska eller andra egenskaper utgör en risk för miljön och/eller hälsan. Lagstiftningen reviderades år 2014 för att vara i enlighet med CLP förordningen. Klassificering av avfall sker i huvudsak på basen av en förteckning över avfall (2014/955/EU). Avfallet klassificeras då antingen som farligt eller icke-farligt beroende på avfallets specifika egenskaper. Enligt kommissionens förordning nr 1357/2014 definieras farliga egenskaper på basen av gränsvärden för olika ämnen. Förordningen hänvisar också till andra egenskaper som klassificerar avfallet som farligt men ofta saknas information om testmetoder som skall användas för att utvärdera dessa egenskaper.

I denna studie presenteras tillägg i lagstiftningen, eventuella konsekvenser och några praktiska utmaningar som relaterar till ändringarna. Rapporten föreslår en stegvis procedur för bedömning av farliga egenskaper och ger en överblick om tillgängliga metoder för insamling av information ifall en bedömning är skall göras på basen av farliga egenskaper. Speciell har bedömning av de farliga egenskaperna "irriterande" (HP4), "frätande" (HP8) och "ekotoxiskt" HP14 behandlats. Den sist nämnda egenskapen lämnades tillfälligt öppen i den reviderade lagstiftningen och här refereras sålunda till tidigare regler. Fyra olika kalkyleringsformler, som föreslagits av kommissionen för bedömning av HP 14, jämförs och bedöms här med avseende på metodens användbarhet. Denna rapport visar också hur avfallets status (farligt eller icke-farligt) inverkar på hanteringen av vissa avfallsströmmar som uppkommer $\mathrm{i}$ stora mängder i Europa.

Följande otydligheter, tolkningsbehov och behov för vägledning rörande bedömning av avfallets status identifierades:

- Det saknas information varför vissa avfall klassas som farliga eller icke-farliga i den europeiska förteckningen över avfall.

- Vidare specificeringar om lämpliga kemiska analysmetoder för bedömning av substanshalten hos avfallsmaterial för klassificering behövs.

- Gemensamma protokoll behövs för vilka ämnen som skall beaktas i ett specifikt avfall. 
- Harmoniserad klassificering för val av faroangivelsekoder (inkluderande $\mathrm{M}$ faktorer om sådana behövs för bedömningen) saknas.

Studiens viktigaste konklusioner och rekommendationer är följande:

- Det behövs en vidare utveckling av europeiska standarder för avfall och en rekommendation om hur standarderna bör användas.

- Det är rimligt att undanta höga $\mathrm{pH}$ värden $(>11,5)$ och alkalinitet som en gräns för HP4/HP8 klassificering av askor, slagg, betongkross och kalkstabiliserade slam från behandling av avloppsvatten. Ifall ett sådant undantag inte är möjligt, rekommenderas användningen av CEN metoder (speciellt pH statiskt test med kontinuerlig pH kontroll) vid bedömning av alkalireserven hos avfall. Biotestmetoderna som nu föreslagits för bedömning av HP14 både underoch överestimerar risken relaterade till utlakade ämnen och en tillräcklig korrelation mellan resultaten från biotesterna och resultaten från kalkyleringsmetoderna saknas.

- Två av de fyra föreslagna kalkyleringsmetoderna för bedömning av ekotoxicitet ansågs potentiella. Dessa två metoder (nämnda som metod 1 och 2) tar i betraktande både akvatisk akuta och akvatisk kroniska egenskaper. Metod 2 inkluderar M faktorer som används i CLP för att ge ökad vikt åt miljömässigt mycket toxiska ämnen och är i full enlighet med CLP. Metod 1 (som saknar M faktorer) är i enlighet med allmän praxis i flera medlemsländer och är även till en viss utsträckning i enlighet med CLP. Harmoniserade M faktorer har dock för tillfället endast definierats för ett mycket begränsat antal ämnen. Därför leder metod 1 till mindre osäker och mindre förändringar i den nuvarande situationen. 


\section{Appendix 1: Testing of alkali reserve method and ecotoxicity methods on selected mineral wastes}

Tommi Kaartinen, Jutta Laine-Ylijoki \& Margareta Wahlström, VTT

\section{Background}

The studies presented here were conducted as part of the Finnish FINHAZ-project. The FINHAZ-project was funded by The Finnish Energy (ET), Finnish Forest Industries Federation, RUDUS Oy, Suomen Erityisjäte Oy, Finnish Solid Waste Association JLY, Association of Finnish Steel and Metal Producers and Oy Nordkalk Ab.

The main goal of the project was to clarify and distribute information on national level about waste classification regarding ashes from energy production, municipal solid waste incineration bottom ash and crushed\&demolished concrete, and to produce experimental data on assessing HP's 4, 8 and 14 on these materials. 


\section{Samples and studies}

\begin{tabular}{|c|c|c|c|c|}
\hline \multirow[t]{2}{*}{ Sample } & \multicolumn{4}{|c|}{ Studies } \\
\hline & $\begin{array}{c}\text { Elemental analysis } \\
\text { (XRF + acid digestion } \\
\text { EN 13656) }\end{array}$ & $\begin{array}{l}\text { Determination of } \mathrm{pH} \\
\text { and alkali reserve } \\
\text { (HP4, HP8) }\end{array}$ & $\begin{array}{c}\text { Determination of } \\
\text { free CaO (EN 451-1, } \\
\text { HP4, HP8) }\end{array}$ & $\begin{array}{l}\text { Ecotoxicity tests } \\
\text { (HP14) }\end{array}$ \\
\hline $\begin{array}{l}\text { Fly ash from SRF in- } \\
\text { cineration }\end{array}$ & $x$ & $x$ & & \\
\hline $\begin{array}{l}\text { Fly ash from coal } \\
\text { combustion }\end{array}$ & $x$ & $x$ & & \\
\hline $\begin{array}{l}\text { Fly ash from } \\
\text { co-incineration of } \\
\text { SRF, peat and wood } \\
\text { biomass }\end{array}$ & $x$ & $x$ & $x$ & \\
\hline $\begin{array}{l}\text { Fly ash from gasi- } \\
\text { fication of SRF and } \\
\text { recycled wood }\end{array}$ & $x$ & $x$ & & $x$ \\
\hline $\begin{array}{l}\text { Fly ash from } \\
\text { combustion of } \\
\text { peat, wood bio- } \\
\text { mass and sludge }\end{array}$ & $x$ & $x$ & $x$ & \\
\hline $\begin{array}{l}\text { Fly ash from } \\
\text { co-incineration of } \\
\text { SRF, wood biomass } \\
\text { and sludge }\end{array}$ & $x$ & $x$ & $x$ & $x$ \\
\hline $\begin{array}{l}\text { Bottom ash from } \\
\text { MSW incineration }\end{array}$ & $x$ & & & $x$ \\
\hline C\&D concrete & $x$ & $x$ & & $x$ \\
\hline
\end{tabular}

The semi-quantified X-ray fluorescence analysis was carried out with a Panalytical Axios mAX $3 \mathrm{~kW}$ X-ray spectrometer and a semi-quantified Omnian-software. The method is applicable for Fluorine and elements heavier than that. Typical detection limit is around $0.01 \mathrm{w}-\%$.

For elementary analysis the samples were grinded in carbon steel bowl and digested in hydrofluoric (HF), nitric (HNO3), and hydrochloric $(\mathrm{HCl})$ acid mixture assisted by microwaves according to SFS-EN 13656. Subsequently, the elements were analysed from the resulting eluate by ICP-MS. 
The determination of alkali reserve (buffering capacity) was performed by two different protocols: titration to $\mathrm{pH} 10$ (Young \& How 1994) and CEN pH-dependence test EN 14997. Based on the alkali reserve, the following calculations were made to evaluate the irritancy and corrosivity of the material:

$$
\begin{aligned}
& \text { If } \mathrm{pH}+1 / 12 \mathrm{x} \text { alkali reserve } \geq 14.5=>\text { corrosive } \\
& \text { If } \mathrm{pH}+1 / 6 \mathrm{x} \text { alkali reserve } \geq 13.0=>\text { irritant }
\end{aligned}
$$

In the method described by Young \& How the alkali reserve is determined by preparing and aqueous dilution of the test material by weighing $10 \mathrm{~g}$ of the test material and adding distilled water to make a mixture with a weight of $100 \mathrm{~g}$. The mixture is then stirred, the initial $\mathrm{pH}$ is recorded, and the mixture is then titrated with $0.5 \mathrm{M}$ sulphuric acid to $\mathrm{pH} 10$. The acid consumption is converted to alkali reserve, which is expressed as grams of $\mathrm{NaOH}$ equivalent per $100 \mathrm{~g}$ of the test material.

In the CEN pH-dependence test (CEN/TS 14997) the test sample (15, 30 or $60 \mathrm{~g}$ ) is mixed with distilled water for 48-hours at L/S ratio 10 . The $\mathrm{pH}$-level of the mixture is kept at the predetermined $\mathrm{pH}$-value $\mathrm{pH}$ range $4-12$ ) by using an automated $\mathrm{pH}$-titrator. Similarly in this case, the acid consumption was converted to $\mathrm{NaOH}$ equivalents to yield the alkali reserve.

The determination of free $\mathrm{CaO}$ was performed according to EN 451-1. The scope of EN 451-1 is fly ash. In the method a test sample is placed to a flask and a mixture of butanolic acid, 3-oxo-ethyl ester (4.2) and butan-2ol is added. The mixture is boiled for 3 hours, the warm mixture is filtered, and the filtrate titrated with hydrochloric acid and with the help of a bromophenol blue indicator to $\mathrm{pH}$ of around 3 . The acid consumption is converted to the content of free $\mathrm{CaO}$ in the sample and expressed as percentages by mass of the dry fly ash.

Tests to measure ecotoxicity of eluates produced from the test materials or alternatively ecotoxicity of a solid material are shown in Table 22. 
Table 22: Tests performed to measure ecotoxicity of the test materials

\begin{tabular}{|c|c|c|c|}
\hline $\begin{array}{l}\text { Test } \\
\text { environment }\end{array}$ & Test & Method & Preparation of eluate \\
\hline Water & ISO 11348-3 & $\begin{array}{l}\text { Inhibition of the light emission } \\
\text { of Vibrio fischeri (Luminescent } \\
\text { bacteria test) }\end{array}$ & $\begin{array}{l}\text { CEN batch leaching test EN } 12457 \text { - } \\
2(\mathrm{~L} / \mathrm{S} 10) \\
\text { For comparison, leaching proce- } \\
\text { dure (L/S } 1000) \text { at fixed } \mathrm{pH} 6\end{array}$ \\
\hline Water & ISO 8692 & $\begin{array}{l}\text { Freshwater algal growth inhibition } \\
\text { test with Desmodesmus subspi- } \\
\text { catus or Pseudokirchneriella sub- } \\
\text { capitata }\end{array}$ & $\begin{array}{l}\text { CEN batch leaching test EN } 12457- \\
2 \text { (L/S } 10) \\
\text { For comparison, leaching proce- } \\
\text { dure (L/S 1000) at fixed } \mathrm{pH} 6\end{array}$ \\
\hline Water & ISO 6341 & $\begin{array}{l}\text { Inhibition of the mobility of } \\
\text { Daphnia Magna }\end{array}$ & $\begin{array}{l}\text { CEN batch leaching test EN } 12457- \\
2 \text { (L/S } 10) \\
\text { For comparison, leaching proce- } \\
\text { dure (L/S } 1000) \text { at fixed } \mathrm{pH} 6\end{array}$ \\
\hline Solid & $\begin{array}{l}\text { ISO } 11296- \\
2: 2013\end{array}$ & $\begin{array}{l}\text { Effects of chemicals on the emer- } \\
\text { gence and growth of higher plants } \\
\text { (Avena sativa, Brassica napus) }\end{array}$ & None \\
\hline
\end{tabular}

As shown in Table 22, the eluates for aquatic ecotoxicity tests were produced by two different methods. In CEN 12457-2 batch leaching the sample (particle size $<4 \mathrm{~mm}$ ) is agitated with de-mineralized water for 24 hours at a liquid-to-solid ratio (L/S) of 10 . The eluate and the solid are separated by filtration $(0.45 \mu \mathrm{m}$ membrane $)$. The leaching procedure performed at L/S 1,000 (Swedish proposal) was done for a material with particle size $<0,125 \mathrm{~mm}$. The $\mathrm{pH}$-level of the mixture was kept at $\mathrm{pH} 6$ by using an automated $\mathrm{pH}$-titrator. Similarly to the CEN procedure, the eluate and the solid were separated by filtration $(0.45 \mu \mathrm{m}$ membrane $)$.

Before ecotoxicity testing for aquatic organisms, the $\mathrm{pH}$ of all the studied eluates prepared according to EN 12457-2 had to be adjusted with acid to $<8.5$.

The interpretation of ecotoxicity test results for the solid samples and for eluates prepared according to EN 12457-2 was done by applying the criteria proposed by INERIS in their national guidance document (Table 23). 
Table 23: Criteria used to interpret ecotoxicity test results for solid samples and eluates prepared according to EN 12457-2(extract from the INERIS report, also other terrestrial tests listed in the INERIS report)

\begin{tabular}{|c|c|c|c|c|}
\hline Test & Endpoints & $\begin{array}{l}\text { EC or LID limit } \\
\text { values: the wa- } \\
\text { ste is HP14 if }\end{array}$ & Duration & Standard \\
\hline \multicolumn{5}{|l|}{ 1. Aquatic tests } \\
\hline $\begin{array}{l}\text { Inhibition of the } \\
\text { light emission of } \\
\text { Vibrio fischeri (Lu- } \\
\text { minescent bacte- } \\
\text { ria test) }\end{array}$ & $\begin{array}{l}\text { Eluate concentration which re- } \\
\text { sults in } 50 \% \text { inhibition of light } \\
\text { emission }\left(\mathrm{EC}_{50}\right) \text {, } \\
\text { or } \\
\text { Dilution step at which light } \\
\text { emission is inhibited by more } \\
\text { than } 20 \% \text { in comparison to the } \\
\text { control }\end{array}$ & $\mathrm{EC}_{50} \leq 10 \%$ & $30 \mathrm{~min}$ & $\begin{array}{l}\text { EN ISO 11348-3 } \\
(2007)\end{array}$ \\
\hline $\begin{array}{l}\text { Freshwater algal } \\
\text { growth inhibition } \\
\text { test with Desmo- } \\
\text { desmus subspi- } \\
\text { catus or Pseudo- } \\
\text { kirchneriella sub- } \\
\text { capitata }\end{array}$ & $\begin{array}{l}\text { Eluate concentration which re- } \\
\text { sults in } 50 \% \text { inhibition of pop- } \\
\text { ulation growth }\left(\mathrm{EC}_{50}\right) \text {, } \\
\text { or } \\
\text { Dilution step at which popula- } \\
\text { tion growth inhibited by more } \\
\text { than } 25 \% \text { in comparison to the } \\
\text { control }\end{array}$ & $\mathrm{EC}_{50} \leq 10 \%$ & $72 \mathrm{~h}$ & $\begin{array}{l}\text { EN ISO } 8692 \\
(2012)\end{array}$ \\
\hline $\begin{array}{l}\text { Inhibition of the } \\
\text { mobility of } \\
\text { Daphnia magna }\end{array}$ & $\begin{array}{l}\text { Eluate concentration which re- } \\
\text { sults in } 50 \% \text { inhibition of mo- } \\
\text { bility }\left(\mathrm{EC}_{50}\right) \text {, } \\
\text { or } \\
\text { Dilution step at which mobility } \\
\text { is inhibited by more than } 20 \% \\
\text { in comparison to the control }\end{array}$ & $\mathrm{EC}_{50} \leq 10 \%$ & $48 \mathrm{~h}$ & $\begin{array}{l}\text { EN ISO } 6341 \\
(2012)\end{array}$ \\
\hline \multicolumn{5}{|l|}{ 2. Terrestrial test } \\
\hline $\begin{array}{l}\text { Effects of chemi- } \\
\text { cals on the emer- } \\
\text { gence and growth } \\
\text { of higher plants } \\
\text { (Avena sativa, } \\
\text { Brassica napus) }\end{array}$ & $\begin{array}{l}\text { Waste concentration which re- } \\
\text { sults in } 50 \% \text { inhibition of } \\
\text { growth }\left(\mathrm{EC}_{50}\right) \text {, } \\
\text { or } \\
\text { Dilution step at which growth } \\
\text { is inhibited by more than } 30 \%\end{array}$ & $\mathrm{EC}_{50} \leq 10 \%$ & $14 \mathrm{~d}$ & $\begin{array}{l}\text { EN ISO 11269-2 } \\
(2012)\end{array}$ \\
\hline
\end{tabular}

\section{Results}

The test results are compiled in Tables 24-28. 
Table 24: Results from elemental analysis performed according to EN 13656. Concentrations of elements are expressed as $\mathrm{mg} / \mathrm{kg}$

\begin{tabular}{|c|c|c|c|c|c|c|c|c|}
\hline & $\begin{array}{r}\text { Fly ash from } \\
\text { SRF incinera- } \\
\text { tion }\end{array}$ & $\begin{array}{r}\text { Fly ash from } \\
\text { coal com- } \\
\text { bustion }\end{array}$ & $\begin{array}{r}\text { Fly ash from co-incineration } \\
\text { of SRF, peat and wood bio- } \\
\text { mass }\end{array}$ & $\begin{array}{r}\text { Fly ash from gasifica- } \\
\text { tion of SRF and recy- } \\
\text { cled wood }\end{array}$ & $\begin{array}{r}\text { Fly ash from combustion of } \\
\text { peat, wood biomass and } \\
\text { sludge }\end{array}$ & $\begin{array}{r}\text { Fly ash from co-incinera- } \\
\text { tion of SRF, wood biomass } \\
\text { and sludge }\end{array}$ & $\begin{array}{r}\text { Bottom ash from MSW } \\
\text { incineration }\end{array}$ & C\&D concrete \\
\hline $\mathrm{Ag}$ & 24.1 & 1.07 & 17.4 & 0.38 & 0.82 & 3.68 & 9.44 & 0,16 \\
\hline Al & 8,490 & 54,500 & 12,600 & 258 & 13,100 & 9,870 & 9,280 & 13800 \\
\hline As & 261 & 60,4 & $<50$ & $<50$ & $<50$ & $<50$ & $<50$ & $<50$ \\
\hline B & 581 & 620 & 305 & $<10$ & 331 & 597 & 525 & 20,9 \\
\hline $\mathrm{Ba}$ & 2,100 & 1,820 & 1,760 & 9.52 & 579 & 556 & 1,670 & 305 \\
\hline $\mathrm{Be}$ & 3 & 9.99 & 3.58 & $<1$ & 4.08 & $<1$ & 1.5 & 2,18 \\
\hline $\mathrm{Bi}$ & 93.4 & 1.57 & 8.58 & 6.05 & 12.1 & 2.11 & 8.22 & 0,31 \\
\hline $\mathrm{Ca}$ & 68,600 & 22,300 & 106,000 & 820 & 37,400 & 27,500 & 56,300 & 21900 \\
\hline $\mathrm{Cd}$ & 30 & $<0.5$ & 13.3 & $<0.5$ & $<0.5$ & 12.4 & 6.93 & $<0.5$ \\
\hline Co & 44 & 93.9 & 35.9 & $<0.2$ & 11 & 22.6 & 45.1 & 6,85 \\
\hline $\mathrm{Cr}$ & 541 & $<100$ & 525 & $<100$ & $<100$ & 150 & 373 & $<100$ \\
\hline $\mathrm{Cu}$ & 5,110 & 94.1 & 1,340 & 8.6 & 86.5 & 2,040 & 2,270 & 22,1 \\
\hline $\mathrm{Fe}$ & 46,200 & 51,800 & 59,600 & 272 & 35,600 & 12,500 & 83,700 & 19500 \\
\hline K & 14,500 & 12,100 & 29,800 & 638 & 27,800 & 16,300 & 17,600 & 20900 \\
\hline $\mathrm{Li}$ & 49,2 & 78,1 & 22,4 & $<20$ & 54,7 & $<20$ & 24,5 & 18,3 \\
\hline $\mathrm{Mg}$ & 8,320 & 2,360 & 10,800 & 114 & 5,420 & 3,070 & 7,200 & 3900 \\
\hline $\mathrm{Mn}$ & 1,300 & 616 & 3,890 & $<20$ & 4,920 & 3,270 & 1,320 & 366 \\
\hline Mo & 40 & 16.3 & 34.7 & 40.7 & 6.42 & 15 & 16 & 1,09 \\
\hline $\mathrm{Na}$ & 15,000 & 9,140 & 15,500 & 389,000 & 12,500 & 17,000 & 37,600 & 16600 \\
\hline $\mathrm{Ni}$ & 238 & 150 & 303 & 2.2 & 32.9 & 191 & 204 & 14 \\
\hline $\mathrm{P}$ & 5,580 & 3,520 & 12,100 & 187 & 10,400 & 7,150 & 8,050 & 387 \\
\hline $\mathrm{Pb}$ & 3,060 & 54.5 & 485 & 35 & 51.6 & 502 & 1,020 & 26,5 \\
\hline $\mathrm{Rb}$ & 53 & 6.63 & 73.3 & 1.83 & 162 & 28.1 & 41.8 & 59,8 \\
\hline s & 37,500 & 8,400 & 39,000 & 158,000 & 10,100 & 27,900 & 12,500 & $<5000$ \\
\hline sb & 573 & 3.82 & 168 & 45.8 & 1.6 & 182 & 76.3 & 0,42 \\
\hline Se & 5 & $<5$ & 7.41 & $<5$ & $<5$ & $<5$ & $<5$ & $<5$ \\
\hline $\mathrm{Si}$ & 123,000 & 193,000 & 144,000 & 1,050 & 181,000 & 94,000 & 195,000 & 235000 \\
\hline $\mathrm{Sr}$ & 505 & 954 & 686 & 4.2 & 528 & 171 & 374 & 157 \\
\hline Th & $<5$ & $<5$ & $<5$ & $<5$ & $<5$ & $<5$ & $<5$ & 1,13 \\
\hline TI & 1 & 3 & 1.46 & 0.19 & 1.75 & 1.25 & 1.81 & 0,67 \\
\hline u & 12.9 & 8 & 6.06 & $<0.1$ & 10.1 & 2.19 & 2.94 & 2,86 \\
\hline v & 114 & 148 & 119 & $<30$ & 75.5 & 45.5 & 60.8 & 41,3 \\
\hline $\mathrm{Zn}$ & 7,480 & 325 & 2,080 & 21.5 & 685 & 2,860 & 2,900 & 81,1 \\
\hline
\end{tabular}


Table 25: Results from XRF-analysis. Concentrations of elements are expressed as percentages (\%)

\begin{tabular}{|c|c|c|c|c|c|c|c|c|}
\hline & $\begin{array}{r}\text { Fly ash from } \\
\text { SRF incinerate } \\
\text { on }\end{array}$ & $\begin{array}{r}\text { Fly ash from coal } \\
\text { combustion }\end{array}$ & $\begin{array}{r}\text { Fly ash from co-incinera- } \\
\text { tion of SRF, peat and wood } \\
\text { biomass }\end{array}$ & $\begin{array}{l}\text { Fly ash from gasification of } \\
\text { SRF and recycled wood }\end{array}$ & $\begin{array}{r}\text { Fly ash from combustion } \\
\text { of peat, wood biomass and } \\
\text { sludge }\end{array}$ & $\begin{array}{r}\text { Fly ash from co-incinera- } \\
\text { tion of SRF, wood biomass } \\
\text { and sludge }\end{array}$ & $\begin{array}{l}\text { Bottom ash from } \\
\text { MSW incineration }\end{array}$ & $\begin{array}{l}\text { C\&D con- } \\
\text { crete }\end{array}$ \\
\hline $\mathrm{Na}$ & 0,74 & 1,4 & 1,1 & 35 & 0,76 & 2,5 & 2,9 & 1,5 \\
\hline $\mathrm{Mg}$ & 1,5 & 1,2 & 2 & 0,02 & 0,88 & 1,6 & 1,8 & 1,3 \\
\hline Al & 9,5 & 12 & 6,4 & 0,03 & 11 & 5,4 & 6,7 & 6,4 \\
\hline $\mathrm{Si}$ & 12 & 24 & 12 & 0,05 & 20 & 14 & 21 & 26 \\
\hline $\mathrm{P}$ & 0,46 & 0,39 & 1,2 & $<0,01$ & 0,88 & 0,79 & 0,78 & 0,05 \\
\hline S & 2,9 & 0,32 & 3,4 & 14 & 0,41 & 3,8 & 0,94 & 0,37 \\
\hline $\mathrm{Cl}$ & 0,12 & 0,02 & 2,4 & 11 & 0,03 & 1,6 & 0,78 & 0,03 \\
\hline K & 1,1 & 1,4 & 2,4 & 0,06 & 2,5 & 2,2 & 1,5 & 2,5 \\
\hline $\mathrm{Ca}$ & 16 & 3,5 & 17 & 0,1 & 15 & 22 & 12 & 13 \\
\hline $\mathrm{Ti}$ & 2,3 & 0,56 & 0,73 & $<0,01$ & 0,39 & 1,1 & 1,3 & 0,3 \\
\hline $\mathrm{Cr}$ & 0,06 & 0,01 & 0,06 & $<0,01$ & $<0,01$ & 0,05 & 0,04 & $<0,01$ \\
\hline $\mathrm{Mn}$ & 0,12 & 0,06 & 0,36 & $<0,01$ & 0,46 & 0,41 & 0,11 & 0,06 \\
\hline $\mathrm{Fe}$ & 3,7 & 4,4 & 5,8 & 0,03 & 3,4 & 3,1 & 6,5 & 3 \\
\hline co & $<0,01$ & 0,01 & $<0,01$ & $<0,01$ & $<0,01$ & $<0,01$ & 0,01 & $<0,01$ \\
\hline $\mathrm{Ni}$ & 0,02 & 0,02 & 0,03 & $<0,01$ & $<0,01$ & 0,02 & 0,01 & $<0,01$ \\
\hline $\mathrm{Cu}$ & 0,45 & 0,02 & 0,14 & $<0,01$ & 0,01 & 0,27 & 0,22 & $<0,01$ \\
\hline $\mathrm{Zn}$ & 0,7 & 0,04 & 0,22 & $<0,01$ & 0,07 & 0,4 & 0,25 & 0,01 \\
\hline As & 0,02 & $<0,01$ & $<0,01$ & $<0,01$ & $<0,01$ & $<0,01$ & $<0,01$ & $<0,01$ \\
\hline $\mathrm{Br}$ & 0,01 & $<0,01$ & 0,04 & 0,05 & $<0,01$ & 0,02 & $<0,01$ & $<0,01$ \\
\hline $\mathrm{Rb}$ & $<0,01$ & $<0,01$ & 0,01 & 0,02 & 0,02 & $<0,01$ & $<0,01$ & 0,01 \\
\hline $\mathrm{Sr}$ & 0,05 & 0,14 & 0,07 & $<0,01$ & 0,07 & 0,07 & 0,04 & 0,03 \\
\hline $\mathrm{zr}$ & 0,03 & 0,02 & 0,01 & $<0,01$ & 0,02 & 0,02 & 0,03 & 0,02 \\
\hline Sn & 0,01 & $<0,01$ & 0,04 & $<0,01$ & $<0,01$ & 0,01 & 0,01 & $<0,01$ \\
\hline Sb & 0,04 & $<0,01$ & 0,01 & $<0,01$ & $<0,01$ & 0,02 & 0,01 & $<0,01$ \\
\hline $\mathrm{Ba}$ & 0,36 & 0,27 & 0,22 & $<0,01$ & 0,14 & 0,31 & 0,22 & 0,09 \\
\hline $\mathrm{Pb}$ & 0,22 & $<0,01$ & 0,04 & 0,01 & $<0,01$ & 0,09 & 0,13 & 0,01 \\
\hline $\mathrm{Bi}$ & 0,01 & $<0,01$ & $<0,01$ & $<0,01$ & $<0,01$ & $<0,01$ & $<0,01$ & $<0,01$ \\
\hline
\end{tabular}


Table 26: Results from determination of alkali reserve and subsequent calculations

\begin{tabular}{|c|c|c|c|c|c|}
\hline Sample & pH & $\begin{array}{l}\text { Alkali reserve, } \\
\mathrm{g} \mathrm{NaOH} / 100 \mathrm{~g}\end{array}$ & $\begin{array}{r}\mathrm{pH}+1 / 6 \mathrm{x} \text { alkali } \\
\text { reserve }\end{array}$ & $\begin{array}{r}\mathrm{pH}+1 / 12 \times \text { al- } \\
\text { kali reserve }\end{array}$ & Interpretation \\
\hline $\begin{array}{l}\text { Fly ash from SRF } \\
\text { incineration }\end{array}$ & 10.3 & 0.08 & 10.3 & 10.3 & $\begin{array}{l}\text { Not irritant, } \\
\text { not corrosive }\end{array}$ \\
\hline $\begin{array}{l}\text { Fly ash from coal } \\
\text { combustion }\end{array}$ & 11.6 & 0.9 & 11.7 & 11.7 & $\begin{array}{l}\text { Not irritant, } \\
\text { not corrosive }\end{array}$ \\
\hline $\begin{array}{l}\text { Fly ash from co-incinera- } \\
\text { tion of SRF, peat and } \\
\text { wood biomass }\end{array}$ & 12.2 & 5.6 & 13.1 & 12.7 & $\begin{array}{r}\text { Irritant, } \\
\text { not corrosive }\end{array}$ \\
\hline $\begin{array}{l}\text { Fly ash from gasification } \\
\text { of SRF and recycled wood }\end{array}$ & 10.5 & 1.3 & 10.7 & 10.6 & $\begin{array}{r}\text { Not irritant, } \\
\text { not corrosive }\end{array}$ \\
\hline $\begin{array}{l}\text { Fly ash from combustion } \\
\text { of peat, wood biomass } \\
\text { and sludge }\end{array}$ & 12.8 & 3.6 & 13.4 & 13.1 & $\begin{array}{r}\text { Irritant, } \\
\text { not corrosive }\end{array}$ \\
\hline $\begin{array}{l}\text { Fly ash from co-incinera- } \\
\text { tion of SRF, wood bio- } \\
\text { mass and sludge }\end{array}$ & 11.8 & 8.2 & 13.2 & 12.5 & $\begin{array}{r}\text { Irritant, } \\
\text { not corrosive }\end{array}$ \\
\hline$C \& D$ concrete & 11.7 & 2.8 & 12.1 & 11.9 & $\begin{array}{l}\text { Not irritant, } \\
\text { not corrosive }\end{array}$ \\
\hline
\end{tabular}

Table 27: Free $\mathrm{CaO}$ contents of selected samples. Concentrations are expressed as percentages (\%)

\begin{tabular}{r|rrr} 
Sample & $\begin{array}{r}\text { Fly ash from co-incineration } \\
\text { of SRF, peat and wood } \\
\text { biomass }\end{array}$ & $\begin{array}{r}\text { Fly ash from co-incineration } \\
\text { of peat, wood biomass } \\
\text { and sludge }\end{array}$ & $\begin{array}{r}\text { Fly ash from co-incineration } \\
\text { of SRF, wood biomass } \\
\text { and sludge }\end{array}$ \\
\hline Free $\mathrm{CaO}, \%$ & 3.2 & 1.2 & 3.9 \\
\hline
\end{tabular}


Table 28: Results from aquatic ecotoxicity testing with two different means of eluate preparation

\begin{tabular}{|c|c|c|c|c|}
\hline Biotest & $\begin{array}{l}\text { Fly ash from gasi- } \\
\text { fication of SRF and } \\
\text { recycled wood }\end{array}$ & $\begin{array}{l}\text { Fly ash from co-incinera- } \\
\text { tion of SRF, wood bio- } \\
\text { mass and sludge }\end{array}$ & $\begin{array}{l}\text { Bottom ash from } \\
\text { MSW incineration }\end{array}$ & C\&D concrete \\
\hline \multicolumn{5}{|c|}{ Eluate prepared at L/S 10 according to EN 12457 and interpreted according to INERIS report } \\
\hline $\begin{array}{l}\text { Inhibition of the } \\
\text { light emission of } \\
\text { Vibrio fischeri } \\
\text { (Luminescent } \\
\text { bacteria test) }\end{array}$ & Not ecotoxic & Not ecotoxic & Not ecotoxic & Not ecotoxic \\
\hline $\begin{array}{l}\text { Freshwater algal } \\
\text { growth inhibition } \\
\text { test }\end{array}$ & Ecotoxic & Not ecotoxic & Ecotoxic & Not ecotoxic \\
\hline $\begin{array}{l}\text { Inhibition of the } \\
\text { mobility of } \\
\text { Daphnia Magna }\end{array}$ & Ecotoxic & Not ecotoxic & Not ecotoxic & Not ecotoxic \\
\hline \multicolumn{5}{|c|}{$\begin{array}{l}\text { Eluate prepared at } \mathrm{L} / \mathrm{S} 1,000(\mathrm{pH} 6) \text { according to a Swedish proposal and interpreted according to notes } 1 \text { and } 2 \text { be- } \\
\text { low }\end{array}$} \\
\hline $\begin{array}{l}\text { Inhibition of the } \\
\text { light emission of } \\
\text { Vibrio fischeri } \\
\text { (Luminescent } \\
\text { bacteria test) }\end{array}$ & Interpretation?* & Interpretation?* & Interpretation?* & Interpretation?* \\
\hline $\begin{array}{l}\text { Freshwater algal } \\
\text { growth inhibition } \\
\text { test }\end{array}$ & Not ecotoxic & $* *$ & $* *$ & Interpretation?* \\
\hline $\begin{array}{l}\text { Inhibition of the } \\
\text { mobility of } \\
\text { Daphnia Magna }\end{array}$ & Not ecotoxic & $* *$ & $* *$ & Not ecotoxic \\
\hline
\end{tabular}

1. * At $50 \%$ dilution, the inhibition percentages were between $1-12 \%$.

Swedish proposal: "any toxic response at $50 \%$ dilution is a case for concern - if you use at chronic biotest. Eg you should not see any toxic response at all to fit the criteria for non-hazardous classification. But it is a very conservative test with a safety factor of 1,000 during leaching. You should be able to use an acute biotest with the same purpose. The test can only predict "non-hazardous" wastes. That is, if the waste does not trigger classification you can be sure that it is not hazardous. If the criteria is exceeded your waste might still be non-hazardous due to the fact the safety factor during leaching is so large."

2. ** Also note that according to the Swedish proposal, toxic effects observed in eluates prepared at $\mathrm{L} / \mathrm{S} 1,000$ at fixed $\mathrm{pH}(6$ or 8,5$)$ are "a case of concern" not necessarily a decision on Hazardous Waste. 


\section{References}

Hennebert P. \& Rebischung, F. (2013). Waste Hazardousness Assessment - Proposition of methods. Report INERIS- DRC-13-136159-04172A- 69 pp. http://www.ineris.fr/ centredoc/drc-13-136159-04172ahazardous-waste-assessment-f3-1379929842.pdf

Young J.R., How M.J., 1994. Product classification as corrosive or irritant by measuring $\mathrm{pH}$ and acid/ alkali reserve. In Alternative Methods in Toxicology vol. 10 - In Vitro Skin Toxicology: Irritation, Phototoxicity, Sensitization, eds. A.Rougier, A.M. Goldberg and H.I Maibach, Mary Ann Liebert, Inc. 23-27. 


\section{Appendix 2: Ecotoxicity testing of 6 wastewater sludges}

Jutta Laine-Ylijoki, Tommi Kaartinen \& Margareta Wahlström, VTT

\section{Background}

The studies presented here were conducted as part of the Finnish HAZLIE-project. The HAZLIE - project was funded by Finnish Water Utilities Association (FIWA), Helsinki Region Environmental Services Authority HSY, Tampere Water, JS-Puhdistamo Oy, Riihimäki, Kymi and Oulu Waterworks and Oy Nordkalk Ab.

The main goal of the project was to clarify and distribute information on national level about waste classification regarding wastewater sludge, and to produce experimental data on assessing HP 14 on waste water sludge samples.

\section{Wastewater sludge generation and management in the Nordic countries}

Sludge is the by-product of wastewater treatment and a complex mixture of numerous organic and inorganic compounds as well as dead and alive micro-organisms. Sludge comprises all material removed from wastewater in different unit processes after screening and grit removal. In addition to the treatment process and the operational parameters applied there, influent characteristics have a major impact on the produced sludge quality. Along with municipal wastewater, municipal wastewater treatment plants commonly receive also other wastewater types, such as industrial effluents, septic tank effluents and agricultural slurries. In the Commission Decision on the European List of Waste (COM 2000/532/EC) the typical class for sewage sludge is "1908 05 sludges from treatment of urban waste water". However, in addition to municipal wastewater most treatment plants receive other wastewater types (e.g. a certain share of industrial wastewater). 
In conventional activated sludge process (CAS) wastewater pretreatment is followed by primary clarification where a part of solids is removed as primary sludge. If chemical precipitation is applied, the chemicals may be added before or at primary clarification or directly to aeration basin. Aeration is the process phase mainly responsible for the degradation of the wastewater organic matter. Micro-organisms, i.e. activated sludge, use the organic content of wastewater to generate energy and new cells. Sludge is separated from the treated water in secondary clarification. A part of sludge is circulated within the plant to optimise the operation. Excess biomass due to organic growth of activated sludge is removed as secondary sludge. Primary and secondary sludges are usually mixed and treated together as mixed raw sludge. In Denmark, Finland and Sweden most of the treatment plants employ tertiary treatment, whereas in Norway the share of tertiary treatment is somewhat smaller $(57 \%$ of the population connected to tertiary treatment) (Eurostat 2015).

According to estimation by Ødegaard (2013) most of the wastewater treatment plants in Finland, Sweden and Denmark apply biological-chemical treatment process. In Norway around half of the treatment plants have mechanical treatment only. In the Nordic countries a vast majority of the total population is connected to urban wastewater treatment plants - the shares in 2010 ranged from 80\% (Norway) to 90\% (Denmark). (Eurostat 2015).

In the Eurostat statistics on sewage sludge, the latest most complete dataset on sludge production and disposal in the Nordic countries is from 2009. At that time, 214, 144 and 108 million kg of sewage sludge as dry solids were generated in Sweden, Finland and Denmark, respectively (Eurostat 2015b). Data for Iceland and Norway were not available.

The utilization and disposal routes for sewage sludge in the Nordic countries in 2008 according to Eurostat (2015b) are summarized in Figure 9. 
Figure 9: Sewage sludge disposal routes in the Nordic countries in 2008 according to Eurostat statistics (Eurostat 2015b). Data for Iceland is not available. For later years the datasets are more incomplete

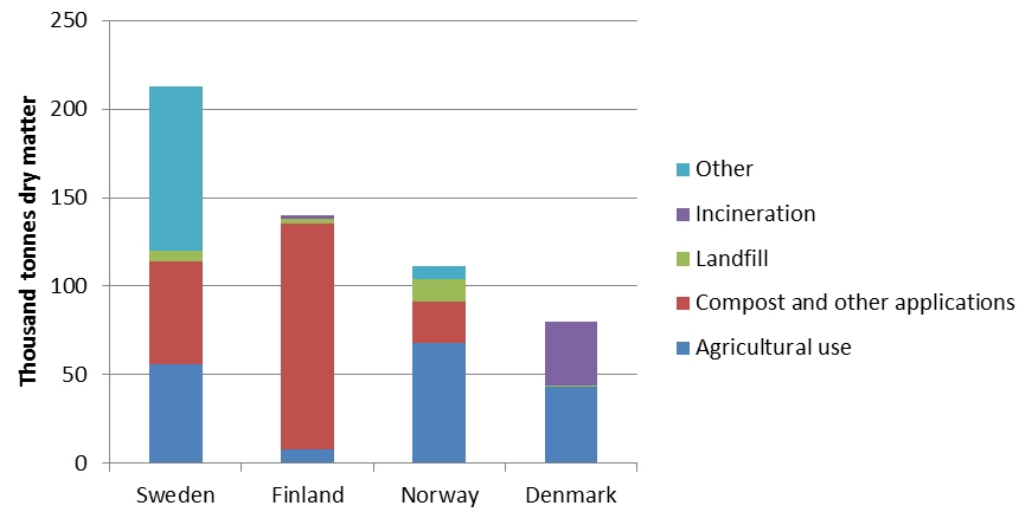

As can be seen from Figure 9, the utilization and/or disposal routes for sludge vary by country. However, agricultural use together with compost and other applications, i.e. use as fertilizer or soil conditioner, represents the majority of sludge utilization routes in all countries. Denmark relies also on incineration whereas in other Nordic countries sludge incineration was virtually not practised in 2008.

Another estimation of sludge disposal routes including Iceland is given in Table 29. The figures are analogous to those presented in Table 9. with regards to total sludge generation (except for Denmark where there seems to be a gap in sludge generation data in the Eurostat statistics) and sludge utilization routes. It is apparent that at least some of the sludge utilized as waste fill cover is reported in other utilization categories in Eurostat statistics (e.g. "landfill" or "other"). 
Table 29: Final sludge disposal as percentages of sludge produced ( $\varnothing$ degaard 2013, Laitinen et al. 2014)

\begin{tabular}{|c|c|c|c|c|c|c|c|}
\hline \multirow{2}{*}{$\begin{array}{l}\text { Country } \\
\text { tons DS/a }\end{array}$} & \multicolumn{3}{|c|}{ Soil improvement/fertilizer } & \multirow[t]{2}{*}{ Incineration } & \multirow{2}{*}{$\begin{array}{r}\text { Waste } \\
\text { fill cover }\end{array}$} & \multirow[t]{2}{*}{ Landfill } & \multirow{2}{*}{$\begin{array}{r}\text { Other/ } \\
\text { unknown }\end{array}$} \\
\hline & Agriculture & Green area & $\begin{array}{r}\text { Soil } \\
\text { production }\end{array}$ & & & & \\
\hline $\begin{array}{l}\text { Denmark } \\
144,000 \mathrm{t} / \mathrm{a}\end{array}$ & $52 \%$ & - & $12 \%^{1}$ & $24 \%$ & - & $1 \%$ & $\begin{array}{r}11 \% \\
\text { (Export 7\%) }\end{array}$ \\
\hline $\begin{array}{l}\text { Sweden } \\
211,000 \text { t/a }\end{array}$ & $25 \%$ & $33 \%$ & - & $1 \%$ & $22 \%$ & $4 \%$ & $17 \%$ \\
\hline $\begin{array}{l}\text { Finland } \\
160,000 \mathrm{t} / \mathrm{a}\end{array}$ & $3-10 \%$ & $45 \%$ & - & $0 \%$ & $20-30 \%$ & $1 \%$ & $10 \%$ \\
\hline $\begin{array}{l}\text { Norway } \\
113,200 \text { t/a }\end{array}$ & $57 \%$ & $9 \%$ & $15 \%$ & $0 \%$ & $14 \%$ & $2 \%$ & $3 \%$ \\
\hline $\begin{array}{l}\text { Iceland } \\
1,556 \text { t/a }\end{array}$ & & & $5 \%^{2}$ & & & 90\% & $5 \%$ \\
\hline
\end{tabular}

1. Sludge mineralization in Denmark.

3. Revegetation in Iceland.

A future forecast by Milieu et al. (2008) on sludge arisings in the EU27 until 2020 estimates that not any significant changes in the sludge amounts would take place in Denmark, Finland or Sweden or any of the EU15 countries in the near future. In contrast, significant growth in sludge arisings is projected for the newer member states (up to 85\% increase from 2010).

Waste classification and relate issues significantly influence the whole treatment and utilization chain of waste - this is true also for sewage sludge. Potential changes in classification have a major impact on waste's status and acceptability on the recycling market and especially in its application in agriculture. For example, when taking into account the use of sludge as soil improvement or fertilizer, it can be estimated from Table 29 that in the Nordic countries the currently utilized sludge volume is ca. 390,000 tonnes of dry solids annually.

\section{Experimental work: Ecotoxicity testing of 6 municipal wastewater sludge samples}

VTT has been carrying out ecotoxicity testing campaign for six municipal wastewater sludge samples during the spring 2015. The ecotoxical tests were conducted at Finnish Environment Institute. The chemical composition of the samples is presented in Table 30. 
Table 30: Composition of wastewater sludge sample. Results from elemental analysis performed according to EN 13656 or semi-quantified X-ray fluorescence analysis XRF-analysis.

Concentrations of elements are expressed as $\mathrm{mg} / \mathrm{kg}$

\begin{tabular}{|c|c|c|c|c|c|c|}
\hline \multirow{2}{*}{$\begin{array}{l}\text { Concentration, } \\
\mathrm{mg} / \mathrm{kg}\end{array}$} & Sludge 1 & Sludge 2 & Slugde 3 & Slugde 4 & Slugde 5 & Sludge 6 \\
\hline & $\begin{array}{r}\text { Mesophilic } \\
\text { anaerobic di- } \\
\text { gestion of } \\
\text { sludge }\end{array}$ & $\begin{array}{r}\text { Mesophilic } \\
\text { anaerobic di- } \\
\text { gestion of } \\
\text { sludge }\end{array}$ & $\begin{array}{r}\text { Centrifuged } \\
\text { raw sludge }\end{array}$ & $\begin{array}{r}\text { Kemicond }^{\circledR} \\
\text { processed } \\
\text { and centrifu- } \\
\text { ged sludge }\end{array}$ & $\begin{array}{r}\text { Nitrification } \\
\text { process, me- } \\
\text { sophilic ana- } \\
\text { erobic dige- } \\
\text { stion }\end{array}$ & $\begin{array}{r}\text { Nitrification } \\
\text { process, me- } \\
\text { sophilic ana- } \\
\text { erobic dige- } \\
\text { stion }\end{array}$ \\
\hline Sodium, $\mathrm{Na}$ & 1,700 & 1,800 & 1,000 & 6,200 & 900 & 1,200 \\
\hline Magnesium, Mg & 3,100 & 3,200 & 1,600 & 1,000 & 2,200 & 2,300 \\
\hline Aluminium, $\mathrm{Al}$ & 9,200 & 8,800 & 3,600 & 22,000 & 17,000 & 13,000 \\
\hline Silicon, Si & 27,000 & 25,000 & 6,200 & 10,000 & 13,000 & 19,000 \\
\hline Phosphorus, P & 33,000 & 33,000 & 17,000 & 20,000 & 35,000 & 24,000 \\
\hline Sulphur, S & 11,000 & 12,000 & 6,200 & 15,000 & 10,000 & 8,200 \\
\hline Chlorine, $\mathrm{Cl}$ & 500 & 500 & 1,700 & 400 & 400 & 400 \\
\hline Potassium, $\mathrm{K}$ & 2,800 & 2,500 & 2,000 & 1,200 & 1,400 & 1,700 \\
\hline Calcium, $\mathrm{Ca}$ & 23,000 & 33,000 & 23,000 & 4,200 & 21,000 & 35,000 \\
\hline Titanium, $\mathrm{Ti}$ & 1,500 & 1,600 & 700 & 800 & 1,900 & 1,600 \\
\hline Chromium, $\mathrm{Cr}$ & 100 & $<100$ & $<100$ & $<100$ & 100 & $<100$ \\
\hline Manganese, Mn & 900 & 400 & 200 & 100 & 600 & 1300 \\
\hline Iron, $\mathrm{Fe}$ & 150,000 & 120,000 & 50,000 & 65,000 & 130,000 & 200,000 \\
\hline Copper, Cu & 200 & 500 & 100 & 200 & 300 & 200 \\
\hline Zinc, Zn & 500 & 600 & 300 & 300 & 600 & 500 \\
\hline Strontium, Sr & 100 & 100 & $<100$ & $<100$ & 100 & 200 \\
\hline Zirconium, Zr & $<100$ & $<100$ & 100 & 100 & 300 & 100 \\
\hline lodine, I & 400 & $<100$ & $<100$ & $<100$ & $<100$ & $<100$ \\
\hline Barium, Ba & 200 & 300 & 100 & 100 & 200 & 400 \\
\hline Silver, Ag & 3.4 & 2.4 & 0.84 & 1.8 & 7.9 & 1.6 \\
\hline Arsenic, As & $<50$ & $<50$ & $<50$ & $<50$ & $<50$ & $<50$ \\
\hline Cadmium, Cd & 0.58 & 0.58 & $<0.5$ & $<0.5$ & 0.54 & 1 \\
\hline Cobolt, Co & 20 & 6,8 & 5.6 & 3.6 & 15 & 43 \\
\hline Molybdenum, Mo & 11 & 5.1 & 5.6 & 3.4 & 9.3 & 10 \\
\hline Nickel, Ni & 31 & 19 & 17 & 12 & 40 & 38 \\
\hline Lead, $\mathrm{Pb}$ & 52 & 20 & 11 & 11 & 18 & 21 \\
\hline Antimony, Sb & 2.4 & 1.7 & 0.56 & 1.5 & 1.2 & 3.6 \\
\hline Vanadium, V & 54 & 30 & $<30$ & $<30$ & 44 & 35 \\
\hline Tin, Sn & 22 & 21 & 14 & 140 & 27 & 17 \\
\hline Selenium,, Se & $<5$ & $<5$ & $<5$ & $<5$ & $<5$ & $<5$ \\
\hline
\end{tabular}


The semi-quantified X-ray fluorescence analysis was carried out with a Panalytical Axios mAX $3 \mathrm{~kW}$ X-ray spectrometer and a semi-quantified Omnian-software. The method is applicable for Fluorine and elements heavier than that. Typical detection limit is around $0.01 \mathrm{w}-\%$.

For elementary analysis the samples were grinded in carbon steel bowl and digested in hydrofluoric (HF), nitric (HNO3), and hydrochloric (HCl) acid mixture assisted by microwaves according to SFS-EN 13656. Subsequently, the elements were analysed from the resulting eluate by ICP-MS.

The studied test methods to assess ecotoxicity were:

\begin{tabular}{|c|c|c|c|}
\hline Test environment & Test & Method & Preparation of eluate \\
\hline Water & ISO 11348-3 & $\begin{array}{l}\text { Inhibition of the light emission } \\
\text { of Vibrio fischeri (Luminescent } \\
\text { bacteria test) }\end{array}$ & $\begin{array}{l}\text { CEN batch leaching test EN } \\
12457-2 \text { (L/S 10) }\end{array}$ \\
\hline Water & ISO 8692 & $\begin{array}{l}\text { Freshwater algal growth inhibi- } \\
\text { tion test with Desmodesmus } \\
\text { subspicatus or Pseudokirch- } \\
\text { neriella subcapitata }\end{array}$ & $\begin{array}{l}\text { CEN batch leaching test EN } \\
12457-2(\mathrm{~L} / \mathrm{S} 10)\end{array}$ \\
\hline Water & ISO 6341 & $\begin{array}{l}\text { Inhibition of the mobility of } \\
\text { Daphnia Magna }\end{array}$ & $\begin{array}{l}\text { CEN batch leaching test EN } \\
12457-2(\mathrm{~L} / \mathrm{S} 10)\end{array}$ \\
\hline Solid & ISO 11296-2:2013 & $\begin{array}{l}\text { Effects of chemicals on the } \\
\text { emergence and growth of } \\
\text { higher plants (Avena sativa, } \\
\text { Brassica napus) }\end{array}$ & None \\
\hline
\end{tabular}

The obtained results from ecotoxicity tests of municipal wastewater sludge samples (eluates prepared according to EN 12457-2 (L/S 10) results interpreted based on proposed criteria by INERIS, France (Hennebert et al. 2013) were the following: 


\begin{tabular}{|c|c|c|c|c|}
\hline \multirow[t]{3}{*}{ Sample } & Water & Water & Water & Solid \\
\hline & $\begin{array}{l}\text { Vibrio fischeri light } \\
\text { emission }\end{array}$ & Algal growth & $\begin{array}{l}\text { Daphnia magna mo- } \\
\text { bility }\end{array}$ & $\begin{array}{l}\text { Growth of avena sa- } \\
\text { tiva (oat) }\end{array}$ \\
\hline & $\begin{array}{l}\text { Interpretation ac- } \\
\text { cording to INERIS } \\
\text { document }\end{array}$ & $\begin{array}{l}\text { Interpretation ac- } \\
\text { cording to INERIS } \\
\text { document }\end{array}$ & $\begin{array}{l}\text { Interpretation ac- } \\
\text { cording to INERIS } \\
\text { document }\end{array}$ & $\begin{array}{l}\text { Interpretation } \\
\text { according to INERIS } \\
\text { document }\end{array}$ \\
\hline $\begin{array}{l}\text { Sludge } 1 \text { from mu- } \\
\text { nicipal waste water } \\
\text { treatment }\end{array}$ & Not ecotoxic & Ecotoxic & $\begin{array}{l}\text { Not applicable, oxy- } \\
\text { gen level too low de- } \\
\text { spite aeration }\end{array}$ & \\
\hline $\begin{array}{l}\text { Sludge } 2 \text { from mu- } \\
\text { nicipal waste water } \\
\text { treatment }\end{array}$ & Not ecotoxic & Not ecotoxic & $\begin{array}{l}\text { Not applicable, oxy- } \\
\text { gen level too low de- } \\
\text { spite aeration }\end{array}$ & \\
\hline $\begin{array}{l}\text { Sludge } 3 \text { from mu- } \\
\text { nicipal waste water } \\
\text { treatment }\end{array}$ & Not ecotoxic & Ecotoxic & $\begin{array}{l}\text { Not applicable, oxy- } \\
\text { gen level too low de- } \\
\text { spite aeration }\end{array}$ & Not ecotoxic \\
\hline $\begin{array}{l}\text { Sludge } 4 \text { from mu- } \\
\text { nicipal waste water } \\
\text { treatment }\end{array}$ & Not ecotoxic & Not ecotoxic & Ecotoxic & \\
\hline $\begin{array}{l}\text { Sludge } 5 \text { from mu- } \\
\text { nicipal waste water } \\
\text { treatment }\end{array}$ & Not ecotoxic & Ecotoxic & Ecotoxic & \\
\hline $\begin{array}{l}\text { Sludge } 6 \text { from mu- } \\
\text { nicipal waste water } \\
\text { treatment }\end{array}$ & Ecotoxic & Ecotoxic & Ecotoxic & \\
\hline
\end{tabular}

Execution and the results from ecotoxicity testing of municipal wastewater sludge samples raised plenty of questions, among which:

- All sludge samples tested either failed or were not suitable for at least one of the three water environment test.

- Is there any hierarchy between different ecotoxicity tests? - Which are key recipients to be protected in this context? - And what is the waste characteristic property we are trying to measure with these tests in this context.

- Low oxygen level in the eluates from sludge samples (and probably also other organic samples) was found hainder the testing, how to proceed? 
- What is the status of ecotoxicity testing in waste classification - does it indicate HPs?

- What is the rationality of terrestial testing of wastes when dilution is needed? How this is done?

Based on results can be concluded, that It seems too early to require ecotoxicity tests for waste classification and hazardous property assessment. The more tests included in evaluation the less samples regardless nonhazardous/hazardous pass through. This means, that in order to require testing one must define the hierarchy of diverse ecotoxicity tests and key recipients to be protected.

\section{References}

Eurostat. (2015). Database Population connected to wastewater treatment plants [env_ww_con]. Extracted 29 April 2015.

Eurostat. (2015b). Database Sewage sludge production and disposal [env_ww_spd]. Extracted 29 April 2015.

Hennebert P. \& Rebischung, F. (2013). Waste Hazardousness Assessment-Proposition of methods. Report INERIS- DRC-13-136159-04172A- 69 pp. http://www.ineris.fr/ centredoc/drc-13-136159-04172ahazardous-waste-assessment-f3-1379929842.pdf

Laitinen, J., Alhola, K., Manninen, K. \& Säylä, J. (2014). Treatment of sewage sludge and biowaste for nutrient recycling. Project report. Finnish Environment Institute (in Finnish). Available: http://www.syke.fi/download/noname/\%7B75C943EE6205-42AA-B130-1105133D5FFF\%7D/105713

Milieu Ltd. WRc and Risk \& Policy Analysts Ltd (RPA). (2008). Study on the environmental, economic and social impacts of the use of sewage sludge on land. Final Report Part II: Report on Options and Impacts. DG ENV.G.4/ETU/2008/0076r. Downloaded 29 April, 2015. Available: http://ec.europa.eu/environment/archives/ waste/sludge/pdf/part_ii_report.pdf

Ødegaard, H. (2013). State of the art of wastewater management in the Nordic countries. NORDIWA 2013 13de Nordiska Avloppskonferensen. Downloaded 28 April 2015. Available: http://www.svensktvatten.se/PageFiles/4083/2\%20\%C3\%98degaard\%20\%20State $\% 20$ of\%20the $\% 20$ art\%20in\%20the\%20Nordic\%20countries.pdf 


\section{Appendix 3: Composition data on bottom ash}

Table 32: Content* of inorganic substances and a few other properties of European bottom ash from grate furnace installations incinerating non-hazardous waste. $N=$ no. of samples. Data on both processed and unprocessed bottom ash are included ${ }^{81}$

\begin{tabular}{|c|c|c|c|c|c|c|c|c|c|}
\hline \multirow[t]{2}{*}{ Substance } & \multirow{2}{*}{$\begin{array}{l}\text { Average } \\
\mathrm{mg} / \mathrm{kg}\end{array}$} & \multirow{2}{*}{$\begin{array}{l}\text { Median } \\
\mathrm{mg} / \mathrm{kg}\end{array}$} & \multirow{2}{*}{$\begin{array}{r}\text { Min } \\
\mathrm{mg} / \mathrm{kg}\end{array}$} & \multirow{2}{*}{$\begin{array}{r}\text { Max } \\
\mathrm{mg} / \mathrm{kg}\end{array}$} & \multirow{2}{*}{$\begin{array}{r}\text { Min 95\% } \\
\text { CL- } \\
\mathrm{mg} / \mathrm{kg}\end{array}$} & \multirow{2}{*}{$\begin{array}{r}\text { Max 95\% } \\
\mathrm{CL}+ \\
\mathrm{mg} / \mathrm{kg}\end{array}$} & \multicolumn{2}{|c|}{95 Percentile } & \multirow[t]{2}{*}{$\mathbf{N}$} \\
\hline & & & & & & & $\mathrm{mg} / \mathrm{kg}$ & $\%$ & \\
\hline $\mathrm{Ca}$ & 130,833 & 125,586 & 50,825 & $1,98,289$ & 58,600 & 370,130 & 190,442 & 19.0 & 322 \\
\hline $\mathrm{CO}_{3}$ & 61,073 & 59,100 & 26,160 & $1,03,800$ & 52,660 & 69,486 & 103,404 & 10.3 & 38 \\
\hline $\mathrm{Fe}$ & 58,714 & 56,703 & 34,216 & $1,18,220$ & 38,424 & 106,400 & 103,299 & 10.3 & 259 \\
\hline $\mathrm{Si}$ & 82,713 & 84,180 & 61,060 & 96,078 & 10 & 115,292 & 93,898 & 9.4 & 129 \\
\hline Al & 47,232 & 44,627 & 30,527 & 75,089 & 28,020 & 112,621 & 71,620 & 7.2 & 311 \\
\hline $\mathrm{Cl}$ & 9,211 & 5,943 & 3,644 & 37,633 & 2,278 & 19,252 & 37,188 & 3.7 & 136 \\
\hline $\mathrm{Na}$ & 21,379 & 22,270 & 12,308 & 34,791 & 6,172 & 40,841 & 32,121 & 3.2 & 234 \\
\hline TOC & 10,092 & 9,340 & 1,350 & 42,760 & 4,330 & 21,230 & 24,664 & 2.5 & 1,382 \\
\hline $\mathrm{Mg}$ & 12,429 & 11,242 & 6,377 & 34,372 & 9,141 & 33,816 & 21,025 & 2.1 & 287 \\
\hline K & 7,748 & 7,595 & 4,854 & 12,722 & 3,156 & 12,919 & 11,857 & 1.2 & 260 \\
\hline$P$ & 5,633 & 5,049 & 2,531 & 12,556 & 3,302 & 10,635 & 11,773 & 1.2 & 220 \\
\hline $\mathrm{Cu}$ & 3,275 & 2,510 & 738 & 17,620 & 1,494 & 6,562 & 8,863 & 0.89 & 1,699 \\
\hline S & 3,862 & 3,475 & 1,310 & 16,808 & 158 & 8,159 & 7,873 & 0.79 & 455 \\
\hline $\mathrm{Ti}$ & 4,244 & 4,112 & 2,873 & 7,479 & 1,174 & 7,111 & 6,636 & 0.66 & 262 \\
\hline $\mathrm{Zn}$ & 3,241 & 2,871 & 1,142 & 9,370 & 1,415 & 6,158 & 6,250 & 0.63 & 1,697 \\
\hline C & 3,171 & 2,919 & 1,119 & 5,702 & 1,200 & 7,147 & 5,383 & 0.54 & 69 \\
\hline $\mathrm{Pb}$ & 1,309 & 1,058 & 197 & 6,441 & 530 & 3,262 & 3,969 & 0.40 & 1,706 \\
\hline $\mathrm{Ba}$ & 1,102 & 958 & 760 & 2,970 & 311 & 2,529 & 2,207 & 0.22 & 288 \\
\hline $\mathrm{Mn}$ & 1,173 & 1,104 & 644 & 2,248 & 547 & 2,620 & $1,965.3$ & 0.20 & 313 \\
\hline $\mathrm{PO}_{4}$ & 248 & 10 & 10 & 1,360 & 95 & 400 & 1,311 & 0.13 & 38 \\
\hline $\mathrm{F}$ & 148 & 71 & 13 & 1,779 & 20 & 692 & $1,219.5$ & 0.12 & 78 \\
\hline $\mathrm{Cr}$ & 353 & 315 & 115 & 852 & 73 & 883 & 754 & 0.075 & 1,701 \\
\hline $\mathrm{NO}_{3}$ & 172 & 100 & 5 & 875 & 94 & 249 & 732 & 0.073 & 38 \\
\hline $\mathrm{Ni}$ & 185 & 153 & 38 & 850 & 29 & 482 & 531 & 0.053 & 1,696 \\
\hline Sn & 181 & 154 & 52 & 737 & 36 & 339 & 519 & 0.052 & 335 \\
\hline B & 198 & 183 & 30 & 532 & 271 & 370 & 401 & 0.040 & 191 \\
\hline $\mathrm{Sr}$ & 271 & 270 & 267 & 369 & 283 & 377 & 356 & 0.036 & 136 \\
\hline $\mathrm{Sb}$ & 73 & 63 & 18 & 250 & 5 & 164 & 159 & 0.016 & 612 \\
\hline $\mathrm{NH}_{4}$ & 53.3 & 46.5 & 5 & 131 & 72.5 & 133.8 & 128 & 0.013 & 43 \\
\hline $\mathrm{NO}_{2}^{-}$ & 13 & 1 & $<1$ & 100 & & & 100 & 0.010 & 38 \\
\hline Co & 31.8 & 23 & 11 & 103 & 10 & 116 & 91.1 & 0.0091 & 376 \\
\hline $\mathrm{Br}$ & 44.7 & 42 & 23 & 95 & 18 & 117 & 80.6 & 0.0081 & 50 \\
\hline Mo & 30.1 & 28 & 5 & 84 & 6 & 220 & 80.6 & 0.0081 & 533 \\
\hline V & 41.2 & 36 & 19 & 248 & 4 & 105 & 76.3 & 0.0076 & 349 \\
\hline As & 17.3 & 14.7 & 4.4 & 73.2 & 2.6 & 49.7 & 46.5 & 0.0047 & 1,615 \\
\hline
\end{tabular}

${ }^{81}$ Hjelmar, O., van der Sloot, H.A. \& van Zomeren, A. (2013): Hazard property classification of high temperature waste materials. Proceedings Saridinia 2013, Fourteenth International 


\begin{tabular}{|c|c|c|c|c|c|c|c|c|c|}
\hline \multirow[t]{2}{*}{ Substance } & \multirow{2}{*}{$\begin{array}{l}\text { Average } \\
\mathrm{mg} / \mathrm{kg}\end{array}$} & \multirow{2}{*}{$\begin{array}{l}\text { Median } \\
\mathrm{mg} / \mathrm{kg}\end{array}$} & \multirow{2}{*}{$\begin{array}{r}\text { Min } \\
\text { mg/kg }\end{array}$} & \multirow{2}{*}{$\begin{array}{r}\text { Max } \\
\mathrm{mg} / \mathrm{kg}\end{array}$} & \multirow{2}{*}{$\begin{array}{r}\text { Min 95\% } \\
\text { CL- } \\
\text { mg/kg }\end{array}$} & \multirow{2}{*}{$\begin{array}{r}\text { Max 95\% } \\
\mathrm{CL}+ \\
\mathrm{mg} / \mathrm{kg}\end{array}$} & \multicolumn{2}{|c|}{95 Percentile } & \multirow[t]{2}{*}{$\mathbf{N}$} \\
\hline & & & & & & & $\mathrm{mg} / \mathrm{kg}$ & $\%$ & \\
\hline $\mathrm{Ag}$ & 15.2 & 14.3 & 2.3 & 47.1 & 0.6 & 83 & 37.5 & 0.0038 & 127 \\
\hline TI & 6.7 & 3.8 & 3.4 & 27.5 & 2 & 18 & 28.6 & 0.0029 & 137 \\
\hline Li & 14 & 14 & 2 & 29 & 2 & 23 & 23 & 0.0023 & 92 \\
\hline Te & 10 & 9.8 & 5.3 & 24.8 & 0.7 & 21 & 22 & 0.0022 & 49 \\
\hline $\mathrm{Cd}$ & 4.8 & 4.3 & 1.1 & 117 & 2 & 32.9 & 13.9 & 0.0014 & 1,661 \\
\hline Se & 5.2 & 4.7 & 2.3 & 12.2 & 2 & 30 & 12.7 & 0.0013 & 145 \\
\hline $\mathrm{Bi}$ & 2.1 & 0.05 & 0.05 & 11.3 & 0.1 & 9.3 & 7.4 & 0.00074 & 34 \\
\hline $\mathrm{Hg}$ & 2.3 & 1.53 & 1.39 & 9.69 & 0.5 & 11 & 7.3 & 0.00073 & 316 \\
\hline
\end{tabular}

Source: (Hjelmar et al., 2013). 


\section{Appendix 4: Geochemical modelling of $\mathrm{Zn}$-species in incineration bottom ash}

Ola Wik, SGI

The results presented are based on the Swedish CREV HP14 project financed by Swedish Waste Management Association, Energiforsk and Swedish Energy Ashes. ${ }^{82}$

A model ash was defined as an assemblage of minerals of interest that has been identified in incineration bottom ashes and reported in the literature. 83 The content of the mineral assemblage were considered for dissolution and, by geochemical modelling, allowed to reach equilibrium. A summary of the mineral assemblage and the collected ecotoxicological classifications for the identified $\mathrm{Zn}$ compounds used in the model ash is given in Table 33 and 34. Data on classification was retrieved from three different sources, CLP Annex VI, REACH registrations and C\&L Inventory data base. If multiple different classifications were registered in the C\&L Inventory data base a classification was chosen that represented an alternative to the previous selections. The modelled content of $\mathrm{Zn}$ was set to $4,700 \mathrm{mg} / \mathrm{kg}$ and thus slightly above the average content in European bottom ash (see Appendix 3).

82 Stiernström, Wik O, Bendz D. 2016. Kritisk utvärdering av metoder för faroklassificering av avfalls ekotoxiska egenskaper (Critical evaluation of methods for hazard classification of waste ecotoxicological properties), In Swedish, Rapport 2016:04, Avfall Sverige 2016.

${ }^{83}$ Stiernström, Wik 0, Bendz D. Critical evaluation of methods for hazard classification of waste ecotoxic properties, Sardinia Conference 2015. 
Table 33: A summary of ecotoxicological data for the selected species of $\mathrm{Zn}$ used as input in geochemical modelling

\begin{tabular}{|c|c|c|c|c|c|c|c|c|}
\hline & & Zincite & $\begin{array}{l}\text { Zinc } \\
\text { chloride }\end{array}$ & $\begin{array}{l}\text { Zinc hy- } \\
\text { droxide }\end{array}$ & $\begin{array}{l}\text { Hydro-zin- } \\
\text { cite }\end{array}$ & $\begin{array}{l}\text { Frankli- } \\
\text { nite }\end{array}$ & Sphalerit & Willemit \\
\hline & & $\mathrm{ZnO}$ & $\mathrm{ZnCl}_{2}$ & $\mathrm{Zn}(\mathrm{OH})_{2}$ & $\begin{array}{l}\mathrm{Zn}_{5}(\mathrm{OH})_{6} \\
\left(\mathrm{CO}_{3}\right)_{2}\end{array}$ & $\mathrm{ZnFe}_{2} \mathrm{O}_{4}$ & ZnS & $\mathrm{Zn}_{2} \mathrm{SiO}_{4}$ \\
\hline \multirow[t]{2}{*}{$\begin{array}{l}\text { CLP Annex } \\
\mathrm{VI}\end{array}$} & $\begin{array}{l}\text { Hazard } \\
\text { code(s) } \\
\text { HP14 }\end{array}$ & $\begin{array}{l}\mathrm{H} 400, \\
\mathrm{H} 410\end{array}$ & $\begin{array}{l}\mathrm{H} 400, \\
\mathrm{H} 410\end{array}$ & - & - & - & - & - \\
\hline & $\begin{array}{l}\text { M-factor } \\
\text { (chronic) }\end{array}$ & - & - & - & - & - & - & - \\
\hline \multirow[t]{2}{*}{$\begin{array}{l}\text { REACH re- } \\
\text { gistrations }\end{array}$} & $\begin{array}{l}\text { Hazard } \\
\text { code(s) } \\
\text { HP14 }\end{array}$ & $\begin{array}{l}\mathrm{H} 400, \\
\mathrm{H} 410\end{array}$ & $\begin{array}{l}\mathrm{H} 400, \\
\mathrm{H} 410\end{array}$ & $\begin{array}{l}\mathrm{H} 400, \\
\mathrm{H} 411\end{array}$ & - & - & $\mathrm{NH}$ & - \\
\hline & $\begin{array}{l}\text { M-factor } \\
\text { (chronic) }\end{array}$ & 1 & 1 & - & - & - & - & - \\
\hline \multirow[t]{2}{*}{$\begin{array}{l}\text { C\&L In- } \\
\text { ventory } \\
\text { data base }\end{array}$} & $\begin{array}{l}\text { Hazard } \\
\text { code(s) } \\
\text { HP14 }\end{array}$ & $\begin{array}{l}\mathrm{H} 400, \\
\mathrm{H} 410\end{array}$ & $\begin{array}{l}\mathrm{H} 400, \\
\mathrm{H} 410\end{array}$ & $\begin{array}{l}\mathrm{H} 400 \\
\mathrm{H} 410\end{array}$ & - & - & $\mathrm{NH}^{*}$ & $\mathrm{NH}$ \\
\hline & $\begin{array}{l}\text { M-factor } \\
\text { (chronic) }\end{array}$ & 10 & 1 & 1 & - & - & - & - \\
\hline
\end{tabular}

$1 \quad$ *Data from joint REACH registration.

2 Abbreviations as follows: - = not relevant or no information (the substance is not entered or not registered), $\mathrm{NH}=$ not hazardous (there is ecotoxicological data but it will not trigger an ecotoxicological classification).

Table 34: Calculated critical concentration of $\mathrm{Zn}$-species that will trigger hazardous waste classification based on information in table 33 and summation Method 2 (see chapter $\mathbf{5 . 3}$ in main report) The concentration has been recalculated to elemental $\mathrm{Zn}$ in order to facilitate comparison with chemical analysis and model ash content of $\mathrm{Zn}$

\begin{tabular}{lllllllll}
$\begin{array}{l}\text { Source of classification } \\
\text { data }\end{array}$ & \multicolumn{7}{l}{$\mathrm{Zn}$-species identified in ash and calculated critical concentration (\%) } \\
& $\mathrm{ZnO}$ & $\mathrm{ZnCl}_{2}$ & $\mathrm{Zn}(\mathrm{OH})_{2}$ & $\mathrm{Zn}_{5}(\mathrm{OH})_{6}\left(\mathrm{CO}_{3}\right)_{2}$ & $\mathrm{ZnFe}_{2} \mathrm{O}_{4}$ & $\mathrm{ZnS}$ & $\mathrm{Zn}_{2} \mathrm{SiO}_{4}$ \\
$\begin{array}{l}\text { CLP Annex VI } \\
\text { REACH Registrations }\end{array}$ & 1.9 & 1.2 & - & - & - & - & - \\
$\begin{array}{l}\text { C\&L Inventory data } \\
\text { base }\end{array}$ & 0.19 & 1.2 & 16 & - & - & $\mathrm{NH}$ & - \\
\hline
\end{tabular}

1. Abbreviations: $-=$ no information classification, $\mathrm{NH}=$ Not classified as hazardous even at $100 \%$ concentration 
The critical concentration for triggering hazard classification varies with a factor of around $500(0.19-100 \%)$ depending on the chosen reference substance and classification, see Table 34 . The most conservative choice is $\mathrm{ZnO}$ which would trigger hazard classification of the modelled ash (and the average European ash) if the most conservative classification of $\mathrm{ZnO}$ identified in CLP-databases is chosen. All other reasonable alternative $\mathrm{Zn}$ reference substances or classifications would result in a non-hazardous classification.

The modelled leaching of dissolved and bioavailable $\mathrm{Zn}$ given as a toxic index potentially triggering chronic aquatic toxicity is shown in Figures 10 and 11. Toxic index is calculated as a quotient between chronic ERV (see chapter 5.2.1 in main report) and modelled or experimental data on leached $\mathrm{Zn}$. The different leaching curves represents the different testing methods (A, B and C) described in in chapter 5.4 of the main report.

It is apparent that leaching with method A at WAF $0.1 \mathrm{~kg} / \mathrm{L}(\mathrm{L} / \mathrm{S} 10)$ and at the $\mathrm{pH}$ controlled of the ash (red dots in Figure 10 and 11) represents a minimum in the leaching of $\mathrm{Zn}$ from the ash. This method is extremely sensitive to the $\mathrm{pH}$ of the leachate (a factor of 100,000). Leaching at the $\mathrm{pH}$ controlled by the ash will thus underestimate the intrinsic properties which according to CLP should be assessed in a pH range between 5.5 and 8.5. At the same time is the hazard overestimated due to the low L/S (high WAF) used in method A. Overall it can be concluded that Method A generates results that are not useful for hazard classification.

Leaching with Method B at WAF $1 \mathrm{~g} / \mathrm{L}$ (L/S 1000) and with $\mathrm{pH}$-control of the leachate (blue dots in Figure 10 and 11) overestimates the hazard (hazard index largely above 1) due to the low L/S (high WAF) used in the method.

Geochemical model predictions for method C at WAF $1 \mathrm{~g} / \mathrm{L}$ (L/S $1,000,000)$ and with $\mathrm{pH}$-control of the leachate (experimental data lacking) indicates that willemite is the best representative $\mathrm{Zn}$ reference substances for bottom ash in equilibrium with water. The classification of willemite as non-hazardous is coherent with the estimated low toxicity index of $\mathrm{Zn}$ over entire relevant $\mathrm{pH}$-range. 
Figure 10: Leaching of $\mathrm{Zn}$ from waste incineration bottom ash based on data from Stiernström et al. $2014^{84}$

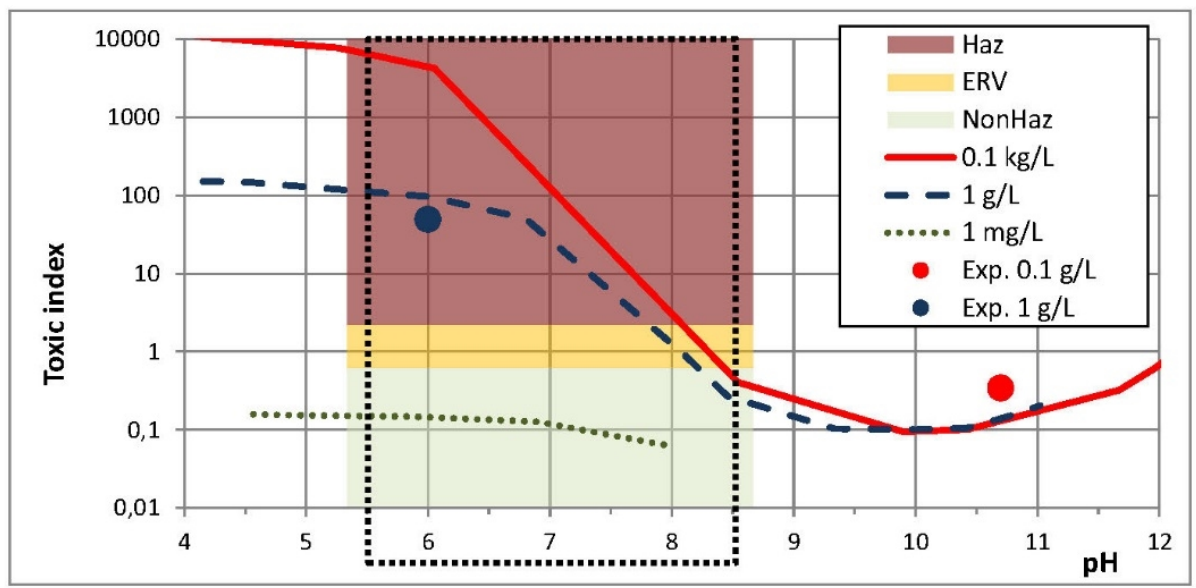

Note: Modelled (lines) and experimental (dots) leaching data for $\mathrm{Zn}$ as a function of WAF (mass of ash per litre of leachate) and $\mathrm{pH}$. The dotted frame represents the classification $\mathrm{pH}$ interval valid under CLP. Classification as hazardous waste is indicated if the toxic index is larger than 1. The range of ERVs triggering hazard classification from Stiernström et al. 2015 (see footnote 85).

Figure 11: Leaching of $\mathrm{Zn}$ from waste incineration bottom ash based on data from FinHaz project (Appendix 1)

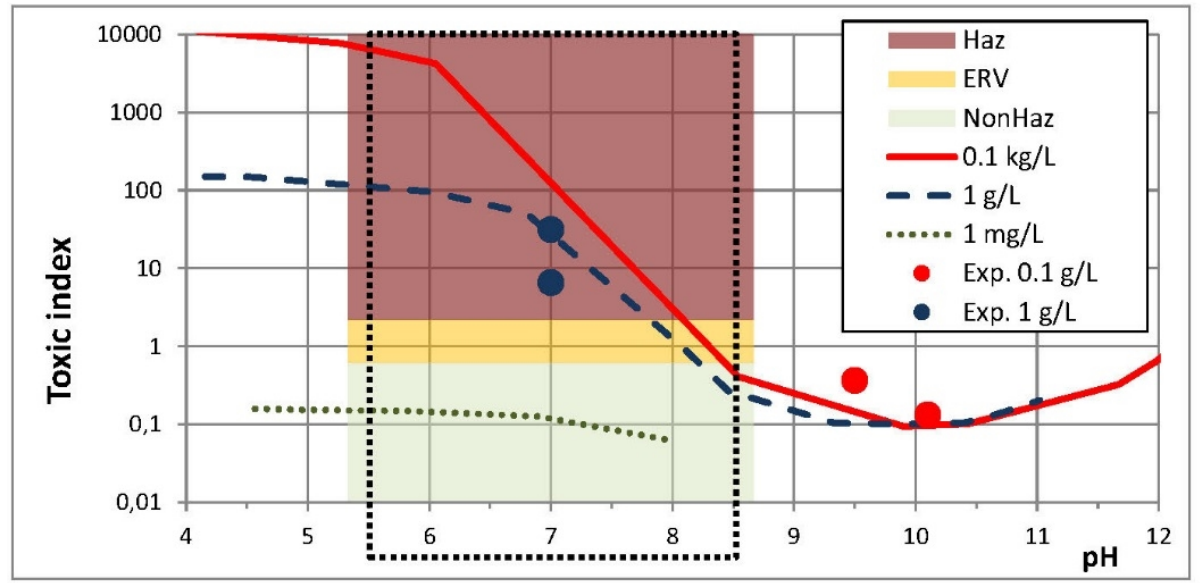

Note: Modelled (lines) and experimental (dots) leaching data for $\mathrm{Zn}$ as a function of WAF (mass of ash per litre of leachate) and $\mathrm{pH}$. The dotted frame represents the classification $\mathrm{pH}$ interval valid under CLP. Classification as hazardous waste is indicated if the toxic index is larger than 1 . The range of ERVs triggering hazard classification from Stiernström et al. 2015 (see footnote 85).

${ }^{84}$ Stiernström, S., Enell A, Wik 0, Hemström K, Breitholtz M., 2014. Influence of leaching conditions for ecotoxicological classification of ash. Waste Management 34(2), 421-429. 
Nordic Council of Ministers

Ved Stranden 18

DK-1061 Copenhagen K

www.norden.org

\section{Hazardous waste classification}

In European legislation, waste is classified either as hazardous or non-hazardous. Hazardous waste is a waste that due to its (intrinsic) chemical or other properties poses a risk to the environment and/ or human health. The legislation for waste classification was revised in 2014 in order to align it with the chemical legislation, the CLP Regulation, but some criteria and assessment procedures for the interpretation of the hazardousness were left open.

Waste classification has several implications on the waste management. This report presents challenges in the hazardous waste classification. In this report, the authors express their views on the interpretation of the waste status, especially focusing on the potentially recyclable high volume waste streams. Also recommendations for the assessement of some hazardous properties are included.

TemaNord 2016:519

ISBN 978-92-893-4532-3 (PRINT)

ISBN 978-92-893-4533-0 (PDF)

ISBN 978-92-893-4534-7 (EPUB)

ISSN 0908-6692

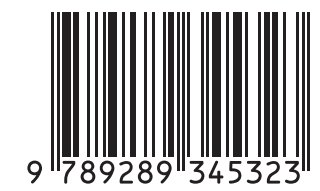

